UNIVERSIDADE DE SÃO PAULO

INSTITUTO DE GEOCIÊNCIAS

\title{
ALOJAMENTO E DEFORMAÇÃO DE PLÚTONS GRANÍTICOS DA EXTREMIDADE NORDESTE DA SUÍTE INTRUSIVA CUNHAPORANGA (DOMÍNIO APIAÍ - FAIXA RIBEIRA, PR)
}

Fabrizio Prior Caltabeloti

Orientador: Prof. Dr. Carlos José Archanjo

DISSERTAÇÃO DE MESTRADO

Programa de Pós-Graduação em Geoquímica de Geotectônica

SÃO PAULO

2011 


\section{Fabrizio Prior Caltabeloti}

Alojamento E DEFORMAÇÃo DE PLÚTONS GRANíTICOS DA EXTREMIDADE NORDESTE DA SUÍTE INTRUSIVA CUNHAPORANGA (DOMÍNIO APIAÍ - FAIXA RIBEIRA, PR)

\footnotetext{
DISSERTAÇÃO APRESENTADA AO INSTITUTO DE GEOCIÊNCIAS DA Universidade de São Paulo para obTenção do título de Mestre EM GEOLOGIA
}

Orientador: Prof. Dr. Carlos José Archanjo

Programa de Pós-Graduação em Geoquímica e Geotectônica

SÃO PAULO 



\section{AGRADECIMENTOS}

Gostaria de expressar minha gratidão a todas as pessoas que colaboraram para realização deste trabalho:

Em primeiro lugar agradeço a toda minha família pelo carinho e apoio. Em especial aos meus pais Odair e Eloisa, aos meus irmãos Fabio e Fabiola, à minha avó Dona Ana Maria, à minha tia Márcia, ao meu sobrinho Pedro, e ao meu cunhado João, e minha cunhada Ariane. Agradeço também ao incentivo e companheirismo de minha futura esposa Renata.

Ao meu orientador Dr. Carlos José Archanjo pelo apoio, orientação e incentivo durante todo trabalho. Agradeço principalmente pela sua grande paciência e disposição em todas as etapas deste mestrado.

À CPRM (Companhia de Pesquisa de Recursos Minerais) e ao Programa de Geologia Básica (PGB), em execução pela CPRM, por todo apoio logístico e custeio com as despesas dos trabalhos de campo. Agradeço também aos grandes amigos de CPRM: Sérgio Wilians, Frederico, Mariane, Mauricio, Márcio, Luiz Gustavo, Vidyã, Felipe Mapa, Marina, Carlos Tomba, Elizete, Mônica, Vanesca, Lauro, Luiz Antonio Chieregati, Garcia, Takahashi e Viviane. Sem esquecer também da contribuição dos estagiários: Denise e Guilherme (Da Lua).

A Fundação de Amparo à Pesquisa do Estado de São Paulo (FAPESP), projeto: "Magmatismo granítico sin- e pós-tectônico do Domínio Apiaí (Faixa Ribeira) e suas implicações para a deformação crustal brasiliana do sudoeste do Estado de São Paulo" (2008/04596-7), pelo apoio e custeio das análises essenciais para a realização deste trabalho.

Aos funcionários do Instituto de Geociências e do laboratório de paleomagnetismo do Instituto de Astronomia, Geofísica e Ciências Atmosféricas da USP. Em especial agradeço a Daniele Brandt pelo apoio e suporte tanto na preparação das amostras como na realização das análises magnéticas. 
A Dra. Maria Helena Bezerra Maia de Hollanda e aos funcionários do CPgeo-USP pelo apoio e pela análise dos dados geocronológicos.

Por último, ao colega Carlos Alejandro Salazar pelo suporte nos trabalhos de campos e na preparação das amostras. 


\section{RESUMO}

Caltabeloti, F. P. Alojamento e deformação dos plútons graníticos da extremidade nordeste da Suíte Intrusiva Cunhaporanga (Domínio Apiaí - Faixa Ribeira,PR). 2011. 95 pp. Dissertação de Mestrado - Instituto de Geociências, Universidade de São Paulo, São Paulo.

Plútons graníticos (Patrimônio Santo Antônio, São Domingos, Ouro Verde e Santa Rita) alojados na porção nordeste da Suíte Intrusiva Cunhaporanga (c. 620-590 Ma) intrudiram metassedimentos pelíticos e carbonáticos de baixo grau metamórfico do Grupo Itaiacoca. Os plútons são isótropos, de coloração cinza a rósea e composição monzo- a sienogranítica, predominando granitóides porfiríticos grossos e, secundariamente, tipos inequigranulares a equigranulares. A cartografia regional mostrou que a foliação das rochas metassedimentares encaixantes mergulha dominantemente para NE e contém uma lineação (interseção, mineral) de direção NNW-SSE. A trama metamórfica das encaixantes assume progressivamente a direção NE-SW conforme se aproxima da zona de cisalhamento transcorrente de Itapirapuã, onde quartzo-milonitos verticalizados exibem uma cinemática sinistral.

A trama dos plútons foi estudada pela técnica da anisotropia de suscetibilidade magnética (ASM). Foram amostradas 40 estações (300 espécimes) no granito porfírítico Patrimônio Santo Antônio, 7 estações (48 espécimes) no granito equigranular fino de São Domingos, 9 estações (67 espécimes) no granito inequigranular de Ouro Verde e 14 estações (92 espécimes) no granito porfiritico foliado de Santa Rita. A suscetibilidade magnética média (k) do granito Patrimônio Santo Antônio é da ordem de 23,29 x $10^{-3}$ SI, enquanto nos granitos Santa Rita $(\mathrm{k}=11,85 \mathrm{mSI})$, São Domingos $(\mathrm{k}=7,43 \mathrm{mSI})$ e Ouro Verde $(\mathrm{k}=7,46 \mathrm{mSI})$ são menores. Por outro lado, a anisotropia magnética $\left(P=k_{\max } / k_{\min }\right.$, onde $\left.k_{\max }>k_{\text {int }}>k_{\min }\right)$ é menor em Patrimônio Santo Antônio $(\mathrm{P}=1,09 \pm 0,04)$ do que no São Domingos $(\mathrm{P}=1,21 \pm$ $0,09)$, Ouro Verde $(P=1,19 \pm 0,07)$ e Santa Rita $(P=1,23 \pm 0,11)$. Estudos termomagnéticos e de magnetização remanente isotermal mostraram que as propriedades magnéticas dos granitoides são dominadas pela magnetita (pobre em Ti) e, secundariamente, Ti-hematita. Sulfetos de Fe (pirita, calcopirita) ocorrem como acessórios. Os óxidos de Fe estão frequentemente associados à titanita, biotita e anfibólio e suas microestruturas são tipicamente magmáticas, exceto no granito Santa Rita onde a microestrutura apresenta evidência de recristalização pós-magmática. 
A foliação magnética dos maciços graníticos mergulha suave a moderadamente e, no plúton Patrimônio Santo Antônio, exibe um padrão tipicamente dômico. A lineação magnética subhorizontal orienta-se na direção NNW-SSE paralelamente ao eixo do dobramento regional das rochas metassedimentares encaixantes. Esta característica indica que os granitos são sin-tectônicos a um evento deformacional cujo controle está aparentemente relacionado ao funcionamento das grandes transcorrências regionais de direção NE-SW. A ocorrência de domos graníticos (Patrimônio Santo Antônio) e elipsóides magnéticos dominantemente prolatos (São Domingos) sugerem que a trama NNW teria sido formada por uma tectônica que combina transcorrência e extensão. Uma idade concordante U-Pb (SHRIMP) em zircão de $589 \pm 6 \mathrm{Ma}$, atribuída à cristalização do plúton Patrimônio Santo Antônio, indica que a deformação que afetou o granito no estado magmático bem como suas encaixantes ocorreu nos estágios finais da formação da Suíte Intrusiva Cunhaporanga.

Palavras chave: Domínio Apiaí, Suíte Intrusiva Cunhaporanga, Anisotropia de susceptibilidade magnética (ASM), mineralogia magnética, Granito Ouro Verde, Granito Patrimônio Santo Antônio, Granito São Domingos e Granito Santa Rita. 


\begin{abstract}
Caltabeloti, F. P. Emplacement and deformation of granitic plutons from northeast of Cunhaporanga Intrusive Suite (Apiaí Domain - Ribeira Belt, PR). 2011. 95 pp. Dissertação de Mestrado - Instituto de Geociências, Universidade de São Paulo, São Paulo.
\end{abstract}

Granite plutons located on the northeast of Cunhaporanga Intrusive Suite (Patrimônio Santo Antônio, Ouro Verde, São Domingos and Santa Rita) are emplaced into low grade metasedimentary rocks (Itaiacoca Group) of the Apiaí Domain (Ribeira Belt). Most of these plutons are isotropic with pinkish to grey colors and their compositions vary from monzogranite to sienogranite. They are usually porphyritic and locally inequigranular and equigranular. Regional mapping revealed that the foliation of the metasedimentary host rocks dips mainly to NE while the lineation (intersection, mineral) strikes in the NNW-SSE direction. The host rocks metamorphic fabric rotates progressively to become parallel to the NE-trending Itapirapuã transcurrent shear zone. Kinematic markers such as elongated quartz grains and mica-fish from quartz-milonites indicate the Itapirapuã shear records a sinistral movement.

The fabric of the plutons was studied by anisotropy of magnetic susceptibility (AMS) technique. Forty sites (300 specimens) were sampled at the Patrimônio Santo Antônio granite, 7 sites (48 specimens) at São Domingos, 9 sites (67 specimens) at Ouro Verde and 14 sites (92 specimens) at Santa Rita granite. The mean of magnetic susceptibility $(\mathrm{k})$ is higher in Patrimônio Santo Antônio granite $\left(\mathrm{k}=23,29 \times 10^{-3} \mathrm{SI}\right)$ and lower in the granites of Santa Rita ( $\mathrm{k}=11,85 \mathrm{mSI})$, São Domingos $(\mathrm{k}=7,43 \mathrm{mSI})$ and Ouro Verde $(\mathrm{k}=7,46 \mathrm{mSI})$. In contrast the magnetic anisotropy $(\mathrm{P})$ is lower in the Patrimônio Santo Antônio granite $(\mathrm{P}=1,09 \pm$ $0,04)$ and higher in the granites São Domingos $(P=1,21 \pm 0,09)$, Ouro Verde $(P=1,19 \pm$ $0,07)$ and Santa Rita $(P=1,23 \pm 0,11)$. Thermomagnetic and Isothermal Remanent Magnetization (IRM) studies show that Ti-poor magnetite is the principal carrier of rock magnetic properties but that includes minor contributions of Ti-hematite. Iron oxides are frequently associated with titanite, biotite and amphibole. Microstructures are typically magmatic, except for Santa Rita granite which shows post-magmatic recrystallized microstructures.

The magnetic foliation of granitic plutons dips smooth to moderately and for the Patrimônio Santo Antônio body it exhibits a typical dome pattern. The subhorizontal magnetic lineation strikes NNW-SSE parallel to regional folding axe of the metasedimentary 
rocks. This feature shows that the granites are syntectonic to a deformation event apparently connected to NE-trending transcurrent shears. The occurrence of a foliation dome in the Patrimônio Santo Antônio pluton and prolate magnetic ellipsoids in São Domingos pluton suggest that the NNW-trending structures includes, besides a strike-slip shear fabric, a component of extension that probably assisted the emplacement of the plutons. A U-Pb (SHRIMP) determination in the Patrimônio Santo Antônio zircons have produced a concordia age of $589 \pm 6 \mathrm{Ma}$ attributed to the crystallization of the granite. These results indicate that in the latest stages of the development of the Cunhaporanga Intrusive Suite the Apiaí Domain was submitted to a regional strain field recording transcurrent simple shear and extension.

Keywords: Apiaí Domain, anisotropy of magnetic susceptibility (AMS), Cunhaporanga Intrusive Suite, magnetic mineralogy, Patrimônio Santo Antônio Granite, Ouro Verde Granite, São Domingos Granite and Santa Rita Granite. 


\section{Sumário}

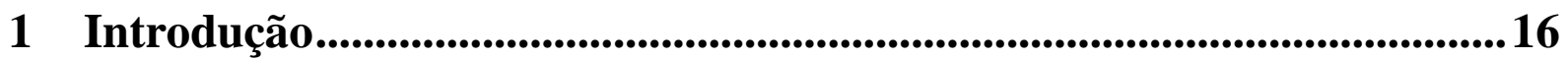

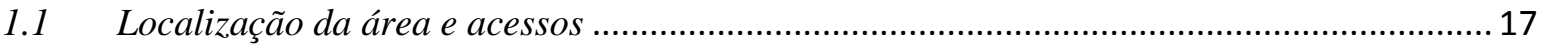

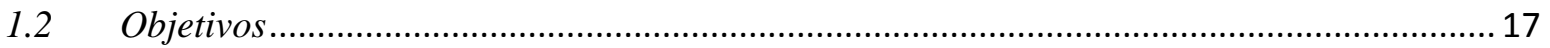

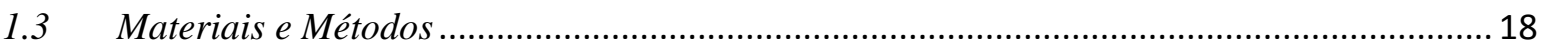

2 Contexto Geológico Regional ..............................................................................21

3 Descrição das unidades mapeadas................................................................25

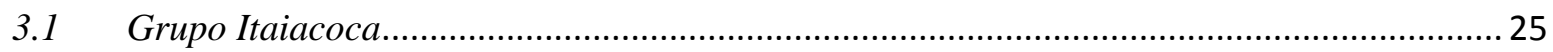

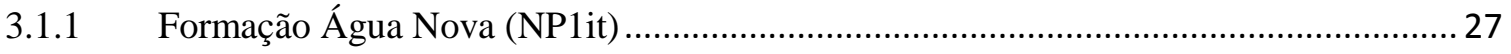

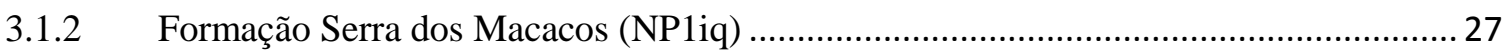

3.1.3 Formação Bairro dos Campos (NP1ic) ................................................................... 28

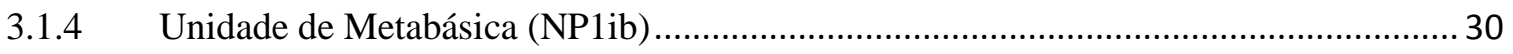

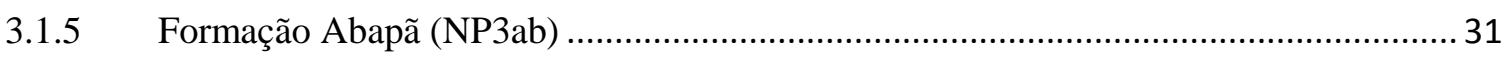

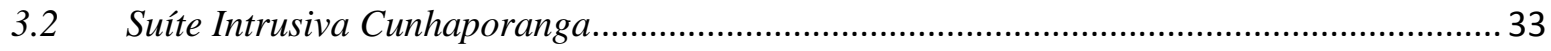

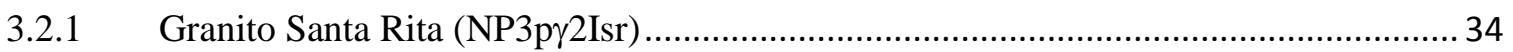

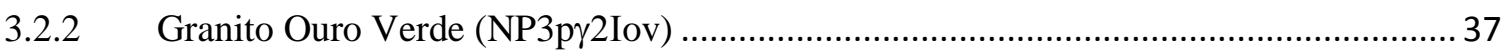

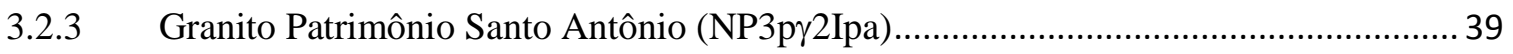

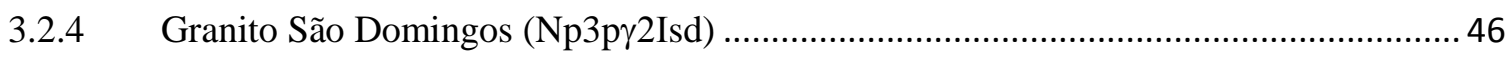

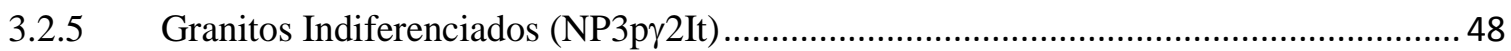

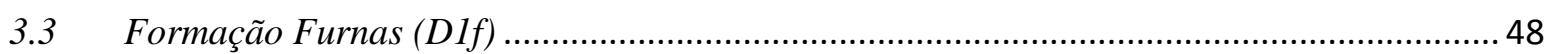

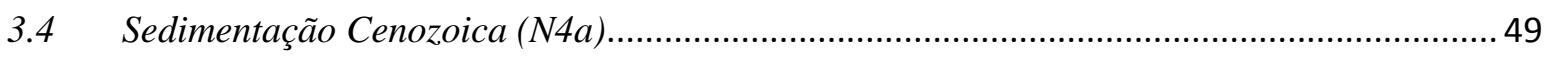

4 Características geofísicas da área de estudo.............................................50

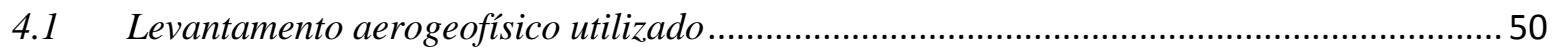

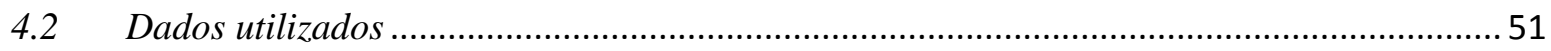

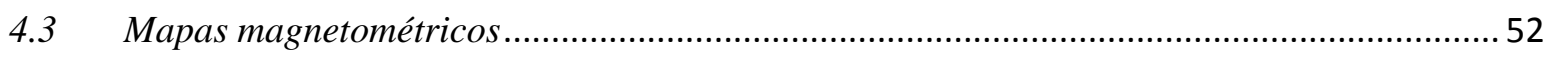

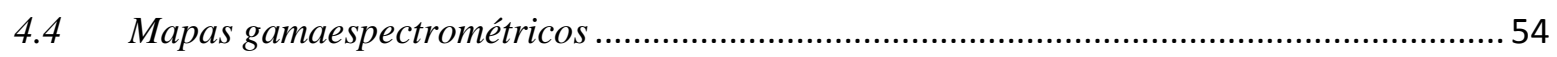

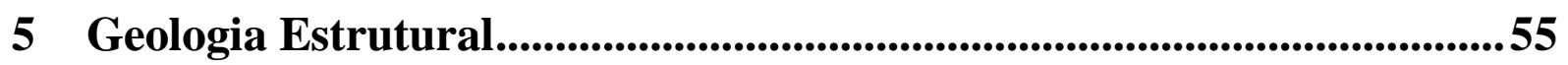

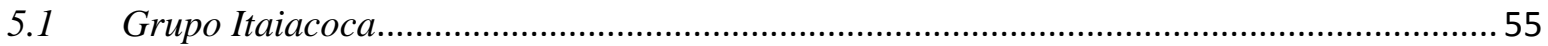

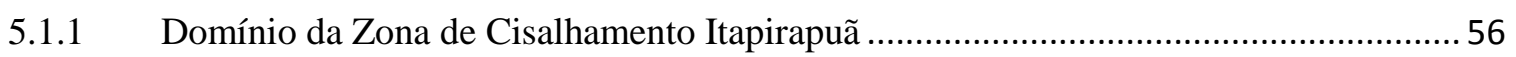

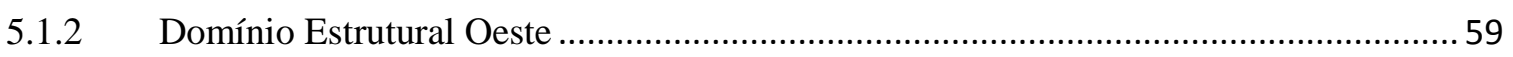

6 Mineralogia Magnética......................................................................63

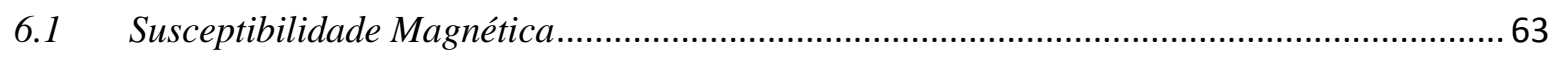

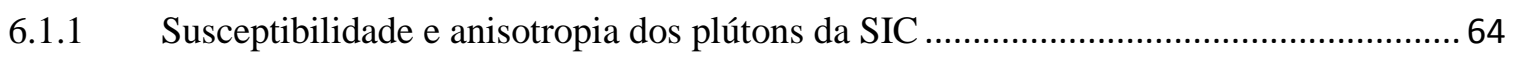

6.1.2 Magnetização remanente isotérmica (IRM) e curvas termomagnéticas ...........................66

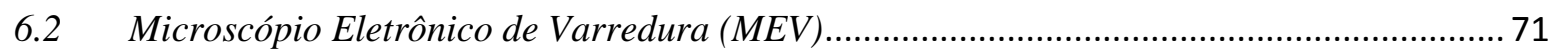

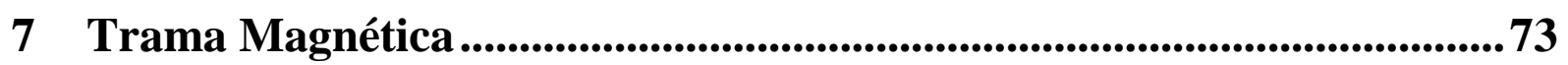

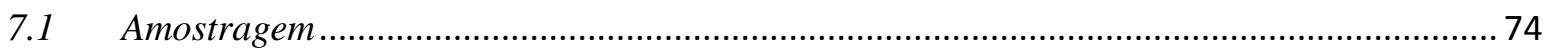

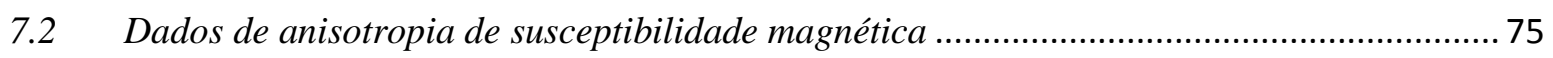

7.3 Parâmetros escalares (anisotropia e forma do elipsóide) ......................................................... 77

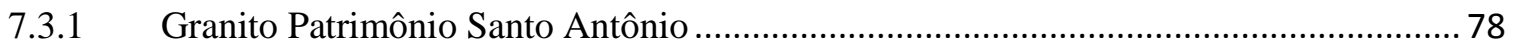

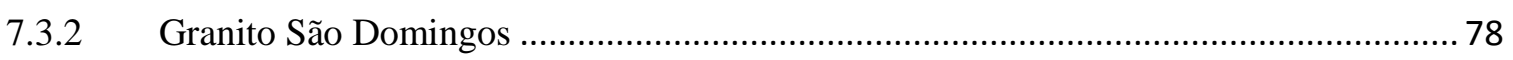

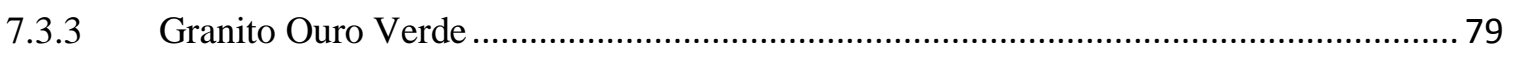




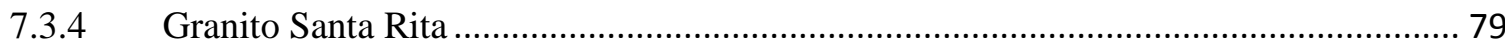

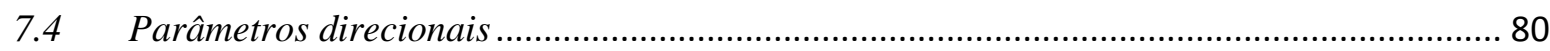

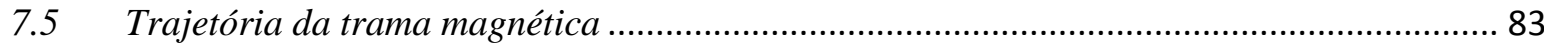

8 Discussões e considerações fỉnais...................................................85

9 Referências bibliográficas .................................................................... 90

ANEXO I - MAPA DE AFLORAMENTOS E ESTAÇÕES DE ASM ........97 


\section{Índice de figuras}

Figura 1-1: Localização da área de estudo e principais acessos ....................................................... 17

Figura 2-1: Mapa geológico do contexto regional (adaptado de Faleiros, 2008) ............................... 23

Figura 2-2: Mapa geológico da área de estudo (adaptado do mapa geológico da Folha Itararé

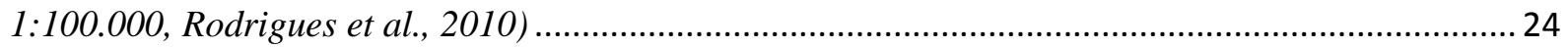

Figura 3-1: Coluna litoestratigráfica do Grupo Itaiacoca ................................................................... 26

Figura 3-2: Foto de metarritmitos finos com intercalações centimétricas de níveis siltosos e níveis de areia fina, caracterizando bandamento composicional contínuo (laminação plano-paralela) da Formação Água Nova (NP1it). (Afloramento SW-16, SP-258-2,5 km a norte de Bom Sucesso de Itararé-SP).

Figura 3-3: Foto da camada de metaconglomerado polimítico (seixos de calcário, siltitos e quartzitos) da Formação Água Nova - Unidade Terrígena (NP1it). (Afloramento SW-16, SP-258 - 2,5 km a norte de Bom Sucesso de Itararé-SP).

Figura 3-4: Foto de quartzitos/metarenitos de granulação fina a muito fina, cor branca, maciço e intensamente fraturado da Formação Serra dos Macacos (NPIiq). (Afloramento SW- 136, Bairro das Almas, Bom Sucesso de Itararé-SP).

Figura 3-5: Foto de quartzitos/metarenitos de granulação fina a muito fina, cor branca, cataclasado/brechado da Formação Serra dos Macacos (NPIiq). (Afloramento SW-711, Serra de Itapirapuã, Doutor Ulysses-PR)

Figura 3-6: Foto de mármores bandados caracterizado por níveis de cor branca, cinza claro e cinza escuro, da Formação Bairro dos Campos (NPIic). (Afloramento SW-303, Pedreira St. Antônio, Mineração S. Judas, Sengés-PR).

Figura 3-7: Foto das estruturas estromatóliticas (laminação cônica) em metacalcilutito da Formação

Bairro dos Campos (NPIic). (Afloramento SW- 463, Bairro Palmeira de Cima, Sengés-PR).....

Figura 3-8: Foto de laminação cruzada em metacalcarenito da Formação Bairro dos Campos (NPIic). (Afloramento SW-145, Bairro os Campos, Bom Sucesso de Itararé-SP).

Figura 3-9: Fotomicrografia com nícois cruzados. Porfiroblastos de tremolita aciculares e orientados. Detalhe para o talco substituindo a tremolita (Afloramento localizado na mina Cerrado da Roseira)

Figura 3-10: Foto de filito/xisto feldspáticos bandados (metawackes) da Unidade de xisto da Formação Abapã (NP3abx). (Afloramento SW-677, Bairro da Estiva, Sengés-PR).

Figura 3-11: Foto de filito/xisto feldspáticos bandados (metawackes) da Unidade de xisto da Formação Abapã (NP3abx). (Afloramento SW- 676, Bairro da Estiva, Sengés-PR).

Figura 3-12: Foto do metarenito rítmico (bandado) com intercalações milimétricas a subcentimétricas de níveis micáceos afetados por pequenas falhas rúpteis. Unidade de metarenitos/metarcóseos da Formação Abapã (NP3aba). (Afloramento SW-336, Serra das Antas, Sengés-PR)

Figura 3-13: Foto de metarenito feldspático estratificação da Unidade de metarenitos/metarcóseos da Formação Abapã (NP3aba). (Afloramento SW-347, Serra das Antas, Sengés-PR) ............................. 32

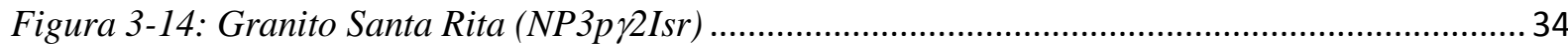

Figura 3-15: Biotita granito porfirítico de cor cinza, do Granito Santa Rita (NP3 $\gamma 2 l s r)$ intercalado com fácies aplítica (Afloramento localizado na estação de ASM 56, Caçador, Doutor Ulysses-PR) .. 35 
Figura 3-16: Biotita sienogranito fanerítico de cor vermelha com veios de fluorita (cor roxa) do Granito Santa Rita (NP3y2lsr). (Afloramento localizado na estação de ASM 55, Caçador, Doutor Ulysses-PR).

Figura 3-17: Fotomicrografia do sienogranito. Detalhe da fluorita preenchendo as microfraturas (Afloramento localizado na estação de ASM 54).

Figura 3-18: Fotomicrografia do sienogranito. Detalhe da recristalização dinâmica do quartzo pelo mecanismo de "bulging" na borda do plagiclásio (Afloramento localizado na estação de ASM 54) . 36

Figura 3-19: Granito Ouro Verde (NP3p 2Iov).

Figura 3-20: Foto do biotita granito fanerítico leucocrático de cor branca, do Granito Ouro Verde

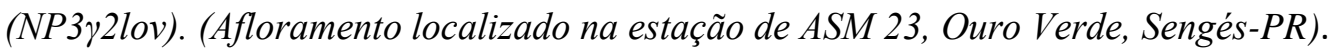

Figura 3-21: Fotomicrografia do enclave microgranular. Leitos de biotita e muscovita alternados com bandas de quartzo e feldspato (Afloramento localizado na estação de ASM 23, Ouro Verde, Sengés-PR)

Figura 3-22: Fotomicrografia com nicóis cruzados do enclave microgranular. Cristais de quartzo recristalizados pelo processo de migração de borda (Afloramento localizado na estação de ASM 23, Ouro Verde, Sengés-PR). 38

Figura 3-23: Granito Patrimônio Santo Antônio (NP3p 2 Ipa).

Figura 3-24: Foto do afloramento típico observado no Granito Patrimônio de Santo Antônio (NP3r2lpa), com grandes matacões e pequenas lajes (Afloramento localizado na estação de ASM 3, Patrimônio de Santo Antônio, Sengés-PR)

Figura 3-25: Foto do biotita granito porfirítico com matriz de granulação grossa com fenocristais idiomórficos de K-feldspato. (Afloramento localizado na estação de ASM 26, Caçador, Doutor Ulysses-PR)

Figura 3-26: Foto do biotita granito porfirítico, com matriz de granulação média, leucocrático e cor branca a rosa clara do Granito Patrimônio Santo Antônio (NP3y2lpa). (Afloramento localizado na estação de ASM 48, Caçador, Doutor Ulysses-PR).

Figura 3-27: Foto do biotita granito fanerítico, hololeucocrático, cor vermelha a rosa clara e granulação grossa do Granito Patrimônio Santo Antônio (NP3 2lpa). (Afloramento localizado na estação de ASM 10, 2 km a leste de Patrimônio de Santo Antônio, Sengés-PR).....

Figura 3-28: Fotomicrografia do biotita monzogranito porfirítico. Cristal de plagioclásio zonado, com extinção do núcleo para a borda (Afloramento localizado na estação de ASM 17).....

Figura 3-29: Fotomicrografia do biotita monzogranito porfirítico. Cristal de microclínio com textura de micropertita (Afloramento localizado na estação de ASM 48)

Figura 3-30: Imagem de catodoluminescência. Mount dos cristais de zircão com marcante zoneamento magmático

Figura 3-31: A) Idade concórdia do Granito Patrimônio Santo Antônio obtida em zircões de um monzogranito porfirítico (Amostra SW-304), e (B) respectiva idade aparente (ver o texto)................ 45

Figura 3-32: Granito São Domingos (NP3p r2Isd)....

Figura 3-33: Foto do biotita granito fanerítico, hololeucocrático, cor vermelha a rosa clara, granulação fina a média, do Granito São Domingos (NP3 $\gamma 2 l s d$ ). (Afloramento localizado na estação de ASM 35, 4 km a sudeste do Bairro São Domingos, Sengés-(PR).

Figura 3-34: Foto do biotita granito fanerítico, hololeucocrático, cor vermelha a rosa clara, granulação fina a média, do Granito São Domingos (NP3 2 2lsd) com vênulas sub-centimétricas. (Afloramento localizado na estação de ASM 35, 4 km a sudeste do Bairro São Domingos, Sengés-(PR) 
Figura 3-35: Fotomicrografia do biotita monzogranito com nicóis descruzados. Biotita cloritizada com associação de opacos e cristais de plagioclásio saussuritizados (Afloramento localizado na estação de ASM 35, 4 km a sudeste do Bairro São Domingos, Sengés-(PR) ........................................ 47

Figura 3-366: Formação Furnas (Dlf)................................................................................ 48

Figura 4-1: Principais levantamentos aerogeofísicos disponíveis na região. A região em azul é referente à área do projeto São Paulo - Rio de Janeiro (Área São Paulo) e a região em amarelo é referente à área do projeto Serra do Mar Sul.....

Figura 4-2: Mapa do campo magnético total reduzido do IGRF (International Geomagnetic Reference

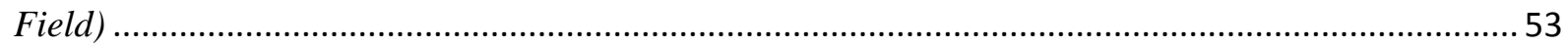

Figura 4-3: Mapa da primeira derivada vertical do campo magnético total ......................................... 53

Figura 4-4: Mapa gamespectrométrico no canal do tório .................................................................... 54

Figura 5-1: Foto exibindo a lineação de crenulação (Lb), associada a uma clivagem de crenulação em filito bandado da Formação Água Nova (NP1it) (Afloramento localizado no ponto SW-316, a noroeste do Bairro São Domingos) .......................................................................................... 56

Figura 5-2: Foto da clivagem disjuntiva espaçada (clivagem de fratura) em metarenito/metaritmito feldspático bandado (metawackes) da Formação Abapã (NP3abx) (Afloramento localizado no ponto SW-114, 2km a noroeste do distrito de Ouro Verde, Sengés - PR) ................................................ 56

Figura 5-3: Campo Magnético total reduzido do IGRF. GPSA e SITC indicam Granito Patrimônio Santo Antônio e Suíte Intrusiva Três Córregos respectivamente ......................................................... 57

Figura 5-4: Domínio da Zona de Cisalhamento Itapirapuã .................................................................58

Figura 5-5: Fotomicrografia de muscovita quartzito com polarizadores cruzados. Detalhe da muscovita com estrutura sigmoidal como mica fish, indicando movimento sinistral. Lado maior da

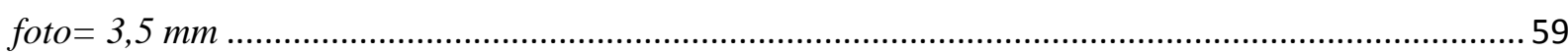

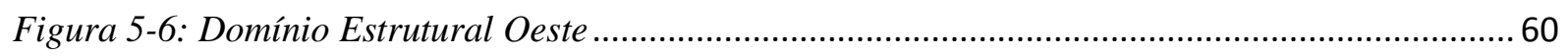

Figura 6-1: Histograma de freqüencia utilizando os dados de susceptibilidade magnética $(k)$ dos plútons da SIC

Figura 6-2: Relação entre anisotropia magnética $(P)$ e susceptibilidade magnética $(k)$ dos plútons da

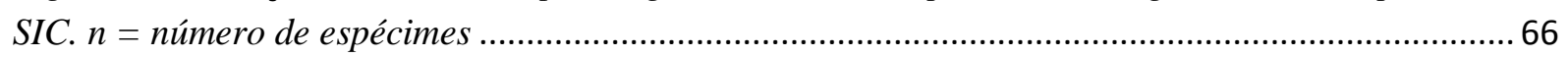

Figura 6-3: Curvas de IRM e termomagnéticas do granito Patrimônio Santo Antônio ......................... 67

Figura 6-4: Curvas de IRM e termomagnéticas dos granitos Santa Rita e Ouro Verde......................... 68

Figura 6-5: Curvas de IRM e termomagnéticas do granito São Domingos.......................................... 70

Figura 6-6: Textura de óxidos de Fe e Ti na SIC. (A) Cristais de magnetita (mt) associado a titanita (Ti); detalhe para a presença de inclusões nas bordas do cristal do titanita. (B) Detalhe de grãos de titanomagnetita inclusos em titanita. Faixas mais escuras, com maior proporção de titânio, alternadas com faixas mais claras com maior proporção de Fe. (C) Associação magnetita, ilmenita, titanita e biotita com contatos retos e encurvados indicativos da cristalização em equilíbrio. A ilmenita (ilm) forma pequenos cristais alongados na borda da magnetita. (D) Cristais de magnetita (mt) e titanita (Ti) envolvendo sulfetos: pirita (pi) e calcopirita (cp). A pirita exibe uma "borda de reação" com aspecto homogêneo formada por ferro e níquel. Detalhe para a presença novamente de titanomagnetita anédrica inclusa na titanita......

Figura 7-1: Representação espacial da trama magnética. A distribuição é considerada triaxial ou plano-linear (a), linear (b) e planar (c) dependendo dos arranjos dos eixos máximo $\left(k_{1}, k_{I A}\right)$, intermediário $\left(k_{2}, k_{2 A}\right)$ e mínimo $\left(k_{3}, k_{3 A}\right)$.

Figura 7-2: Estações de amostragem para medida de anisotropia de susceptibilidade magnética (ASM) da Suite Intrusiva Cunhaporanga . 
Figura 7-3: Distribuição da anisotropia de susceptibilidade magnética média $(P)$ de cada estação para os granitos da área de estudo. O grau de anisotropia é menor na porção NNW e maior na região SSE.

Figura 7-4: Histograma do grau de anisotropia $(P)$ e forma do elipsóide $(T)$ no granito Patrimônio Santo Antônio

Figura 7-5: Histograma do grau de anisotropia $(P)$ e forma do elipsóide $(T)$ no granito São Domingos

Figura 7-6: Histograma de frequência do grau de anisotropia $(P)$ e forma do elipsóide $(T)$ no granito Ouro Verde.

Figura 7-7: Histrograma de frequência do grau de anisotropia $(P)$ e forma do elipsóide $(T)$ do granito Santa Rita

Figura 7-8: Variação angular da elipse de confiança das direções principais de ASM para cada estação. A trama é considerada definida se $\alpha k_{1,3}<28^{\circ}$ e dispersa se $\alpha k_{1,3}>42^{\circ}$

Figura 7-9: Orientação da trama magnética ( $k_{1}$, lineação magnética e $k_{3}$, foliação magnética)gerada pela média de cada estação nos plútons da área de estudo. Projeção estereográfica no hemisfério inferior. $N$, número de estações de ASM.

Figura 7-10: Mapas da foliação magnética (k3) e da lineação magnética (k1) e sua distribuição para cada plúton. Estereograma com contorno de densidade. Hemisfério inferior. Projeção em áreas iguais. $N$, número de espécimes ....

Figura 7-11: Trajetória da trama magnética. Detalhe para o padrão concêntrico do granito Patrimônio Santo Antônio.

Figura 8-1: Modelo de alojamento de granito em sítios transtensivos (modificado de D'Lemos et al. 1992)

Figura 8-2: A) Modelo dos esforços na transcorrência destral. B) Sítio transtensiva gerado pela deformação que combina um componente de transcorrência destral e extensão (Te) (Román-Berdiel et al. 1997). C) Distribuição da lineação magnética nos plútons da área de estudo. D) Distribuição das lineações de estiramento e mineral no Domínio Estrutural Oeste.

Figura 8-3: A) Modelo dos esforços na transcorrência sinistral. B) Modelo do estiramento na transcorrência sinistral (Román-Berdiel et al. 1997). C) Distribuição da lineação magnética nos plútons da área de estudo. D) Distribuição das lineações mineral e estiramento no Domínio Estrutural Oeste 


\section{Introdução}

Em geral, os granitos são frequentemente descritos como rochas maciças (isótropas) e sem orientação aparente de seus minerais constituintes. A caracterização das tramas (fabrics) de rochas graníticas a partir do estudo da anisotropia de suscetibilidade magnética (ASM) veio demonstrar que os granitos apresentam estruturas passíveis de serem analisadas e que dificilmente podem ser considerados totalmente isótropos (Bouchez, 1997). A ASM é reconhecida como uma ferramenta importante na caracterização de tramas minerais em rochas a partir dos anos 50 (Graham, 1954), sendo que atualmente é utilizada para determinação da petrotrama em diferentes tipos de rochas. Sínteses de suas aplicações são apresentadas por Rochette et al., 1992 (ígneas máficas); Borradaile e Henry, 1997 (ígneas plutônicas félsicas) e Canon-Tapia, 2004 (vulcânicas).

Atualmente a ASM é largamente utilizada para caracterizar a estrutura interna de corpos ígneos e seus mecanismos de alojamento (Bouchez, 2000), sendo que, numerosos estudos estruturais utilizando essa e outras técnicas confirmam a forte conexão entre a trama magmática e a deformação regional, especialmente em zonas de cisalhamento (e.g., Hutton, 1988; Vigneresse, 1995; Brown e Solar, 1998; Cruden, 2006 etc.). O estudo da relação entre o magmatismo e a deformação constitui uma das ferramentas essenciais para entender os mecanismos de transferência de massa e diferenciação da crosta e, assim, a própria evolução estrutural de um orógeno.

Nesta dissertação é apresentada a ASM dos granitos Patrimônio Santo Antônio, Ouro Verde, São Domingos e de uma pequena porção do Granito Santa Rita. Estes corpos graníticos são associados à Suíte Intrusiva Cunhaporanga, que compõe um amplo e extenso batólito de idade ediacarana (ca. 650-590 Ma) intrusivo nas rochas metassedimentares de baixo grau associadas ao Grupo Itaiacoca, unidades constituintes do Terreno (ou Domínio tectônico) Apiaí (segmento do Cinturão Ribeira Meridional da Província Mantiqueira). A ASM forneceu a trama destes corpos, permitindo estabelecer relações entre o magmatismo e as estruturas adjacentes. Também foi realizado estudo detalhado da mineralogia magnética dos plútons estudados, a partir de análises petrográficas (Microscopia óptica e MEV-EDS) e termomagnéticas. 


\subsection{Localização da área e acessos}

A área de estudo (fig. 1-1) está localizada próxima à divisa interestadual entre Paraná e São Paulo, mais precisamente no município de Sengés (PR). Geograficamente a região investigada está situada entre os paralelos $24^{\circ} 18^{\prime} 00^{\prime \prime} \mathrm{S}$ e $24^{\circ} 28^{\prime} 00^{\prime \prime} \mathrm{S}$ e meridianos $49^{\circ} 29^{\prime} 00^{\prime} \mathrm{W}$ e $49^{\circ} 22^{\prime} 00^{\prime \prime} \mathrm{W}$.

A partir da cidade de São Paulo, o acesso à área de estudo é feito pela rodovia Castelo Branco (SP-280) até o município de Tatuí (SP). Posteriormente percorre-se a estrada Antônio Romano Schincariol (SP-127) por $102 \mathrm{~km}$ até região de Capão Bonito (SP), para enfim utilizar a via Francisco Alves Negrão (SP-258) por $140 \mathrm{~km}$ e um pequeno trecho da rodovia PR-239 até Sengés (PR).

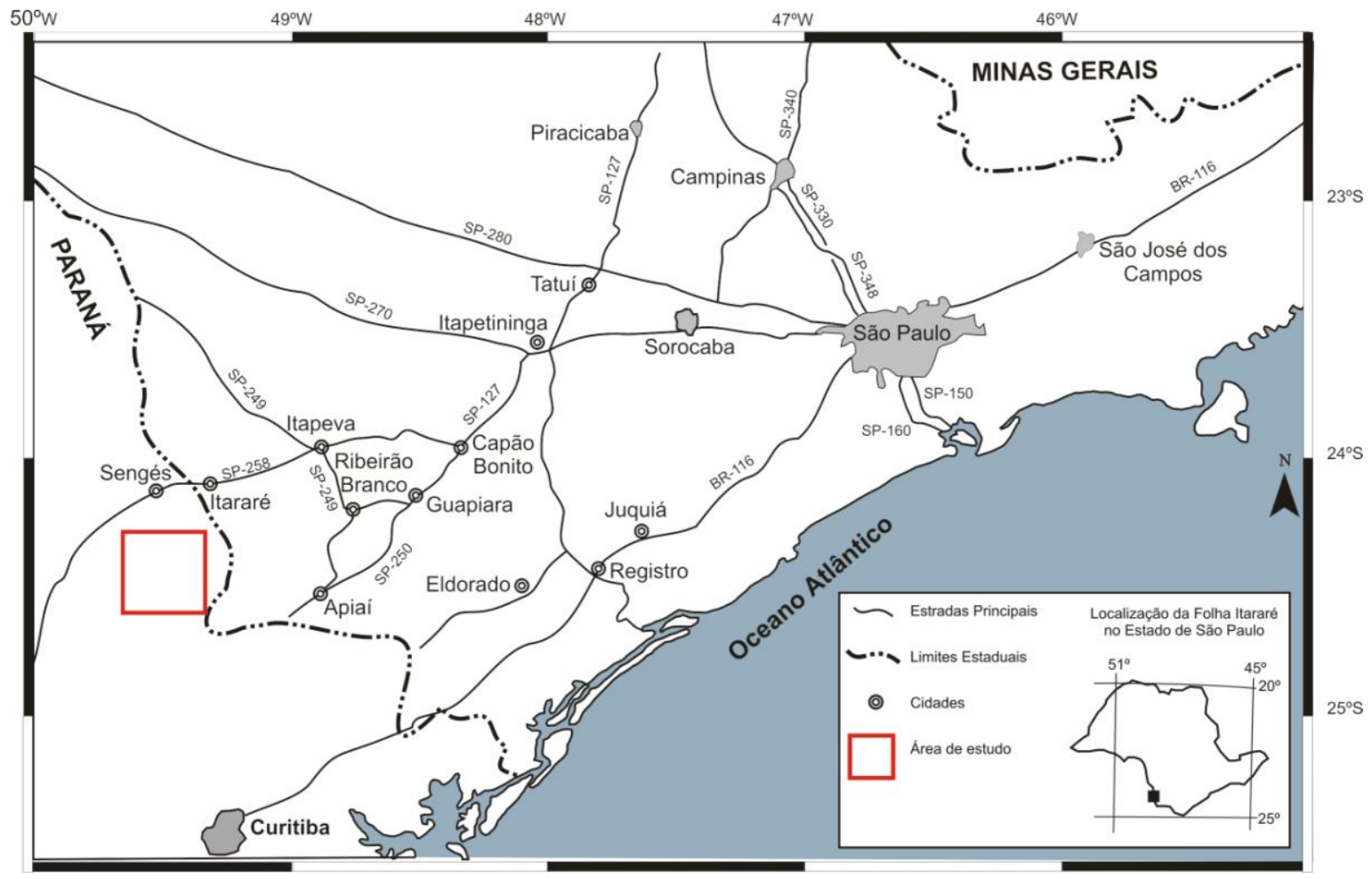

Figura 1-1: Localização da área de estudo e principais acessos

\subsection{Objetivos}

Este presente trabalho tem os seguintes objetivos:

(i) Mapear os contatos dos corpos graníticos estudados estabelecendo as relações estruturais com as rochas encaixantes; 
(ii) Determinar a trama magmática dos granitos Patrimônio Santo Antônio, Ouro Verde, São Domingos e Santa Rita através da ASM;

(iii) Caracterizar a mineralogia magnética

(iv) Elaborar um modelo para alojamento e deformação dos plútons graníticos da Suíte Intrusiva Cunhaporanga encontrados na área de estudo.

\subsection{Materiais e Métodos}

Para caracterizar a mineralogia e a trama magnética, as amostras estudadas foram submetidas aos seguintes procedimentos:

- Susceptibilidade Magnética: A metodologia de amostragem e de obtenção de dados de anisotropia de suscetibilidade magnética são descritos por Bouchez (1997). A susceptibilidade magnética volumétrica e a respectiva anisotropia foram determinadas em espécimes orientados de 2,5 cm de diâmetro e 2,2 cm de altura (totalizando um volume de $10,8 \mathrm{~cm}^{3}$ ) com um suscetibilímetro do tipo Kappabridge KLY-4S (AGICO) do Laboratório de Paleomagnetismo do Instituto de Astronomia, Geofísica e Ciências Atmosféricas (IAG) da Universidade de São Paulo (USP). Também neste equipamento foram realizadas as análises termomagnéticas que serão descritas no próximo item. Este equipamento possui uma sensibilidade da ordem de $2 \times 10^{-8} \mathrm{SI}\left(300 \mathrm{Am}^{-1}\right)$ e precisão $<0,3 \%$. Ele fornece as principais direções de anisotropia $(\mathrm{k} 1>\mathrm{k} 2>\mathrm{k} 3)$, de modo que a susceptibilidade do espécime é dada por $\mathrm{k}=1 / 3$ $(\mathrm{k} 1+\mathrm{k} 2+\mathrm{k} 3)$. Foram amostradas no total 70 estações de ASM e distribuídas da seguinte maneira: 40 estações (300 espécimes) no Granito Patrimônio Santo Antônio, 7 estações (48 espécimes) no Granito São Domingos, 9 estações (67 espécimes) no Granito Ouro Verde e 14 estações (92 espécimes) no Granito Santa Rita.

- Análise termomagnética: Trata-se de uma análise da variação de susceptibilidade em função da temperatura $(\mathrm{k}-\mathrm{T})$. As análises termomagnéticas forneceram as Temperaturas de Curie/Néel $\left(\mathrm{T}_{\mathrm{C}} / \mathrm{T}_{\mathrm{N}}\right)$ para cada fase magnética presente na amostra, medindo-se a susceptibilidade magnética no intervalo de $200^{\circ} \mathrm{C}$ a $700^{\circ} \mathrm{C}$. A variação k-T foi investigada introduzindo a amostra em um forno (CS-3/CS-L) acoplado ao Kappabridge. A amostra consistiu de um 
fragmento de rocha moído (fração areia fina a silte) e homogeneizado, separando-se um pequeno volume para análise $\left(0,2 \mathrm{~cm}^{3}\right)$. Inicialmente o material foi resfriado em nitrogênio líquido até atingir a temperatura de $200^{\circ} \mathrm{C}$. Em seguida a amostra foi aquecida progressivamente até temperatura ambiente, com a susceptibilidade magnética sendo medida em intervalos de aproximadamente $3^{\circ} \mathrm{C}$. Posteriormente a mesma amostra foi reaquecida da temperatura ambiente até $700^{\circ} \mathrm{C}$ e novamente resfriada à temperatura ambiente. Neste ciclo de aquecimento - resfriamento também foi medida a susceptibilidade em intervalos de $3^{\circ} \mathrm{C}$, entretanto a amostra encontra-se envolvida em uma atmosfera de argônio que limita as reações de oxidação durante o experimento. As curvas termomagnéticas que representam a variação k-T foram analisadas utilizando o software Cureval v.8 da AGICO Ltda.

- Magnetização remanente isotérmica (IRM): Este método consiste na indução de um campo magnético crescente através de um dispositivo do tipo Pulse. As amostras utilizadas são distintas das amostras da análise termomagnética, porém oriundas da mesma estação. Inicialmente foi medida a Magnetização Remanente Natural (MRN) no espécime e, em seguida, aplicou-se o campo magnético de forma gradual até 2,2 T. Este campo foi induzido ao longo do eixo do espécime (direção $z$ ) e a magnetização remanente medida no magnetômetro da MOLSPIN Ltda do Laboratório de Paleomagnetismo do Instituto de Astronomia, Geofísica e Ciências Atmosféricas (IAG) da Universidade de São Paulo (USP). A curva resultante da IRM representa a capacidade de aquisição da magnetização remanente dos minerais ferromagnéticos em temperatura ambiente, também conhecida como coercividade.

- Microscópio Eletrônico de Varredura com Espectrômetro de Energia Dispersiva (MEV-EDS): Os minerais opacos contribuem significativamente para a susceptibilidade e anisotropia das rochas graníticas. Foram escolhidas duas amostras que apresentavam a maior susceptibilidade magnética para serem analisadas no Microscópio Eletrônico de Varredura (MEV) acoplado a um Espectrômetro de Energia Dispersiva (EDS). O sistema MEV permitiu a obtenção de imagens de elétrons retroespalhados (BSE), realçando minerais compostos por elementos de elevado número atômico. O EDS forneceu uma 
análise química pontual semiquantitativa dessas fases auxiliando na identificação dos minerais portadores de magnetismo. As análises foram efetuadas no Laboratório de Microscopia Eletrônica de Varredura do Instituto de Geociências (IGc) da Universidade de São Paulo. 


\section{Contexto Geológico Regional}

Os granitos caracterizados neste estudo são inseridos na porção meridional do Cinturão Ribeira (Almeida et al., 1973), integrante da Província Mantiqueira (Almeida et al., 1977, 1981). O Cinturão Ribeira compreende um largo segmento crustal paralelo à linha costeira do sudeste brasileiro, tendo sido amalgamado, deformado e metamorfizado durante a Orogenia Brasiliano-Pan Africana (Neoproterozoico ao início do Paleozoico). Consiste de um complexo orógeno colisional relacionado às colisões oblíquas entre os crátons Paranapanema, São Francisco e Congo e à consolidação do continente Gondwana Ocidental (Brito Neves et al., 1999; Campanha \& Brito Neves, 2004; Fuck et al., 2008). Atualmente, conforme Faleiros (2008) reconhece-se no Cinturão Ribeira a presença de diversos blocos retrabalhados de origens distintas, incluindo rochas antigas de embasamento alóctones, suítes de rochas vulcano-sedimentares mesoproterozoicas e neoproterozoicas e suítes granitóides intrusivas de afinidade diversas.

Apesar das diferentes denominações e interpretações, podem-se distinguir quatro domínios tectônicos (fig.2-1) ou terrenos na Faixa Ribeira Meridional, conforme Faleiros (2008): o Terreno (ou Domínio) Apiaí, Luís Alves, Curitiba e Paranaguá (ou Costeiro). Esses domínios consistem de segmentos crustais do Sistema Orogênico Mantiqueira, resultantes da colisão neoproterozoica entre os crátons São Francisco, Congo e Paranapanema. A amalgamação dos crátons aos domínios adjacentes culminou no supercontinente Gondwana Ocidental (Brito Neves et al. 1999).

A área de estudo situa-se no Domínio Apiaí a norte da Zona de Cisalhamento de Itapirapuã (ZCI) (fig. 2-1). Esta região apresenta na literatura diversas denominações, tais como Faixa Itaiacoca (Reis Neto, 1994), Compartimento Campina dos Veados (Siga Jr et al., 2003) e Compartimento Abapã (Prazeres Filho, 2005). O termo "Faixa Itaiacoca" é o mais amplamente utilizado e reconhecido.

A Faixa Itaiacoca é limitada a SSE pela Zona de Cisalhamento Itapirapuã e a NNW pelas rochas do Grupo Castro (fig. 2-1). Ela é constituída predominantemente pelo grupo homônimo (Almeida 1956, Bistrichi et al., 1985; Fairchild, 1977; Souza 1990; Reis Neto 1994; Prazeres Filho et al., 1998 etc), que é intrudido pela Suíte Intrusiva Cunhaporanga. O Grupo Itaiacoca é distribuído em uma faixa alongada com largura média de $10 \mathrm{~km}$ e direção NE-SW, desde a região de Itaiacoca (PR) até Itapeva (SP). Corresponde a uma sequência de 
rochas metavulcanossedimentares de baixo grau metamórfico fortemente afetadas por zonas de cisalhamento rúpteis/dúcteis e por intrusões graníticas ediacaranas, principalmente associadas à Suíte Intrusiva Cunhaporanga.

A Suíte Intrusiva Cunhaporanga (SIC) é representada principalmente por monzo- e sienogranitos de coloração rósea a cinza médio e, secundariamente, por granodioritos e quartzo-monzonitos (Guimarães, 2000). Predominam granitoides porfiríticos com cristais de feldspato potássico centimétricos e subordinadamente granitoides equigranulares a inequigranulares. Os contatos do SIC com as litologias do Grupo Itaiacoca no geral são descritos como intrusivos, sendo comum o desenvolvimento de metamorfismo de contato (Prazeres Filho et al., 1998 e Szabó et al., 2006). Na área de estudo (fig. 2-2) ocorrem os seguintes granitos associados à unidade, que serão discutidos no capítulo a seguir: Ouro Verde, Patrimônio Santo Antônio, Santa Rita e São Domingos. 


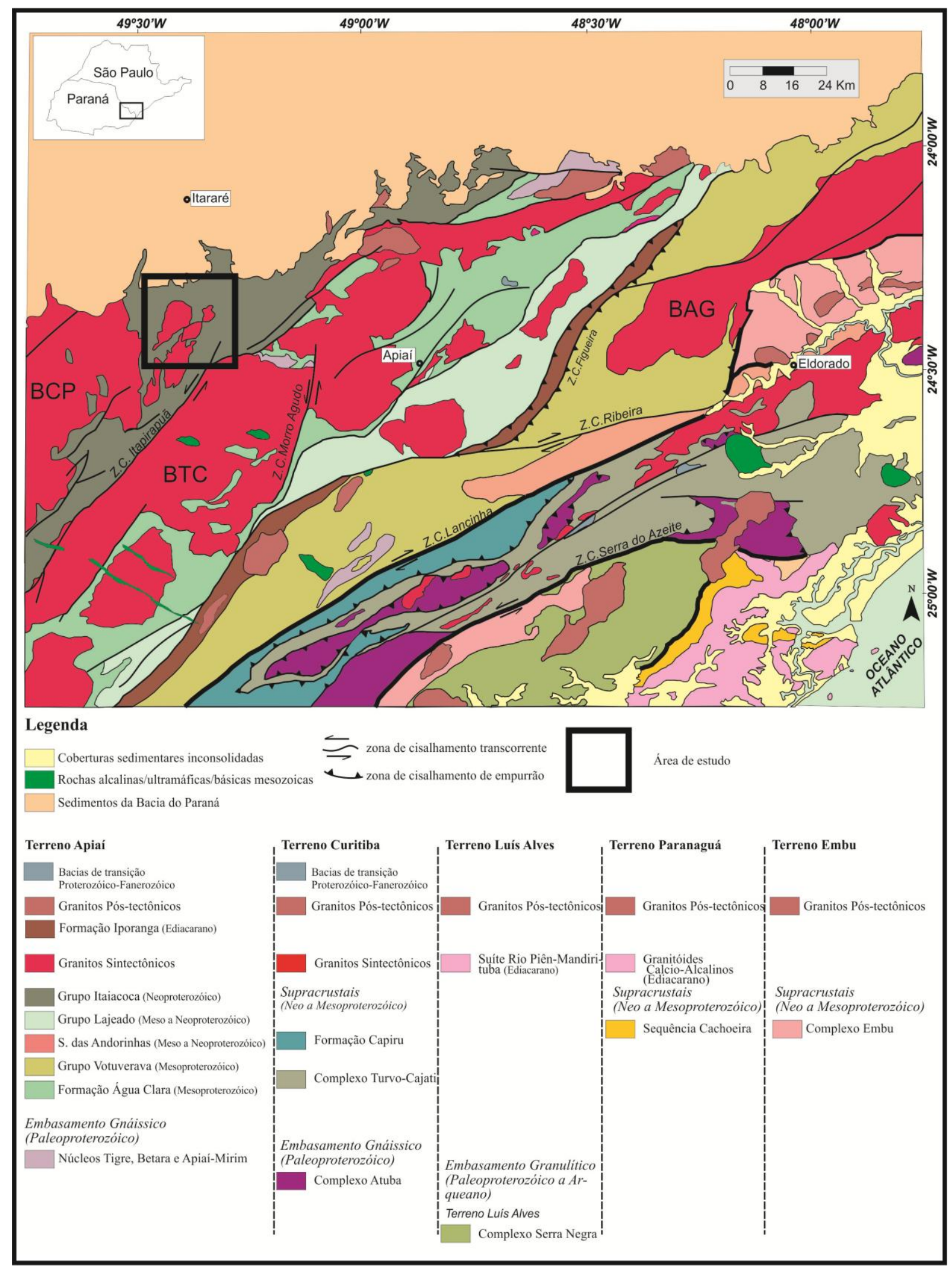

Figura 2-1: Mapa geológico do contexto regional (adaptado de Faleiros, 2008) 


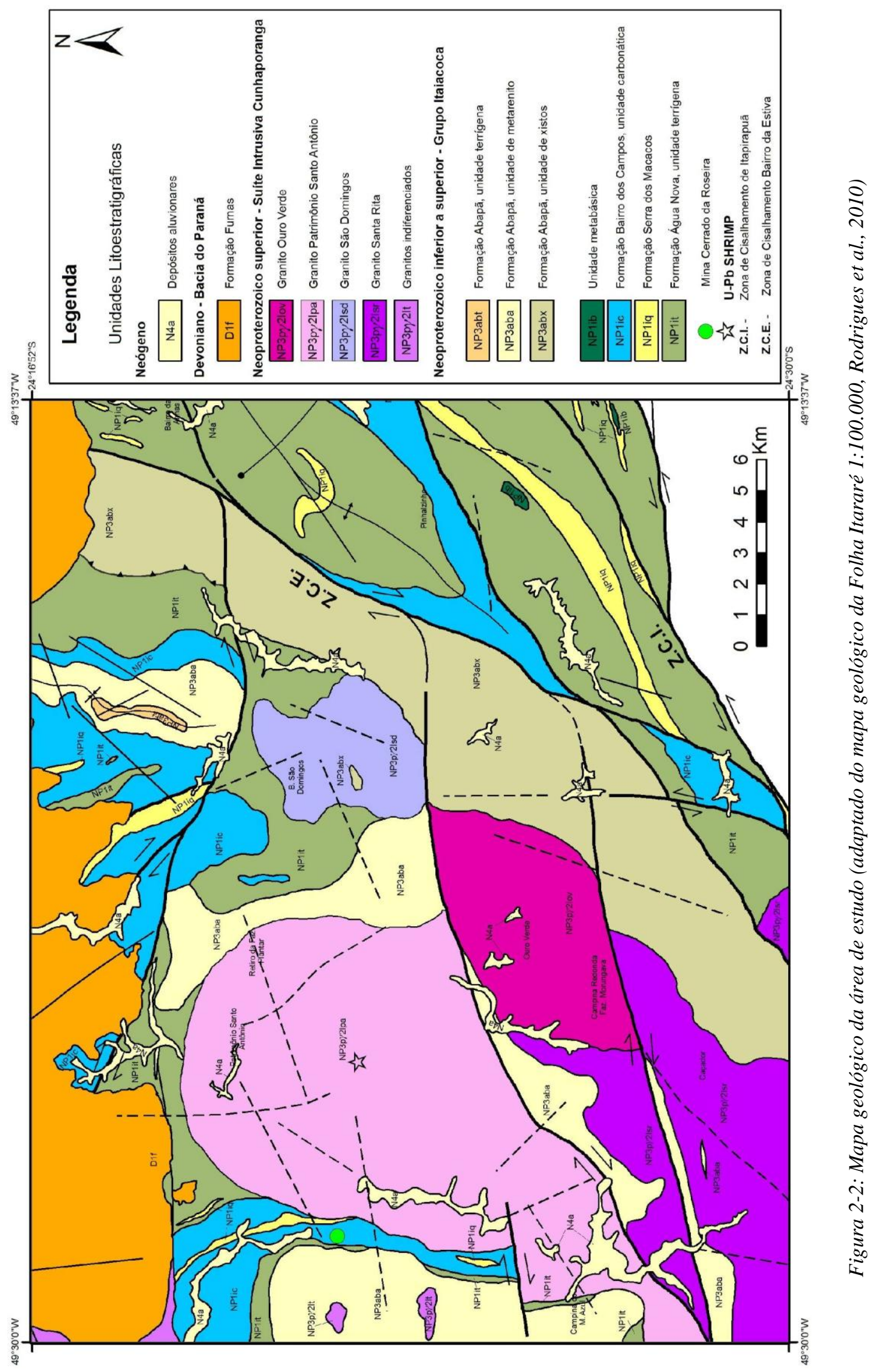




\section{Descrição das unidades mapeadas}

A partir da década de 70, a área estudada foi coberta por diversos projetos de mapeamentos sistemáticos em escalas regionais (Algarte et al., 1972; Algarte et al. 1974 e Silva et al., 1981) e de semi-detalhe (Muratori et al. 1970; Soares et al., 1987). Alguns trabalhos acadêmicos ligados à universidade também têm contribuído para a cartografia geológica, destacando-se: Souza (1990), Gimenez Filho (1993), Guimarães, (2000), Prazeres Filho (2000 e 2005). Atualmente a área estudada foi coberta por levantamento geológico efetuado por Rodrigues et al. (2009) e Caltabeloti et al (2010) na Folha Itararé (SG.22-X-B-I, escala 1:100.000) junto à Companhia de Pesquisa de Recursos Minerais (CPRM).

No levantamento geológico efetuado foram utilizados a metodologia e os procedimentos padrões elaborados pelo Programa Geologia do Brasil (PGB), em execução pela CPRM. Além disso, o projeto foi totalmente desenvolvido em ambiente SIG (Sistema de Informações Geográficas) e vinculado ao Banco de Dados Geológicos da CPRM (GEOBANK).

A escala adotada de trabalho na área estudada foi 1: 50.000 para detalhar as estruturas observadas, assim como complementar os dados geológicos já existentes. Este procedimento permitiu refinar a cartografia geológica principalmente das unidades graníticas.

Neste capitulo serão apresentadas as descrições das unidades litoestratigráficas mapeadas, da base para o topo. No anexo I consta o mapa geológico com a localização das estações de ASM e os afloramentos utilizados como referência para as fotos do Grupo Itaiacoca e a Formação Abapã.

\subsection{Grupo Itaiacoca}

O Grupo Itaiacoca representa a unidade mais antiga na área estudada, correspondendo a uma sequência de rochas metavulcanossedimentares de baixo grau metamórfico que ocorre numa faixa de direção NE-SW entre os estados de São Paulo e Paraná (fig. 2-1). Estas rochas são afetadas por zonas de cisalhamento e falhas dúcteis e rúpteis, além de intrusões graníticas associadas aos plútons da Suíte Intrusiva Cunhaporanga.

O Grupo Itaiacoca apresenta diversas propostas de arranjo estratigráfico, sendo destacados os trabalhos de Trein et al. (1985), Bistrichi et al. (1985), Theodorovicz et al. 
(1986), Souza (1990), Reis Neto (1994) e Prazeres Filho et al. (1998). Nos últimos anos, a partir de dados geocronológicos U-Pb, na região paranaense de Abapã e Socavão, Siga Jr et al. (2009 e 2003) definiram o empilhamento estratigráfico deste grupo em duas grandes unidades litoestratigráficas: uma sequência basal de rochas metacarbonáticas e metapelitos, de idades associadas ao final do Mesoproterozoico e início do Neoproterozoico (1030-908 Ma: U-Pb em zircões de rochas metabásicas, Siga Jr et al., 2009); e uma sequência superior de rochas metavulcanoclásticas, metarenitos arcoseanos e metapelitos do final do Neoproterozoico (645-628 Ma: U-Pb, em zircões de rochas metavulcânicas, Siga Jr et al., 2003).

Neste trabalho são adotadas cinco unidades/formações litoestratigráficas (fig. 3-1), sendo utilizada a nomenclatura apresentada nos trabalhos de Souza (1990) e Reis Neto (1994) e também considerado o empilhamento estratigráfico proposto por Siga Júnior et al. (2003 e 2009). São elas da base para o topo: Formação Água Nova (NPlit), Formação Serra dos Macacos (NPliq), Formação Bairro dos Campos (NPlic), Unidade Metabásica (NPlib) e Formação Abapã (Unidade de metarenito/metarcóseos - NP3aba; Unidade Terrígena NP3abt; e Unidade de xistos $-N P 3 a b x)$.

As unidades mais antigas, de idades do final do Mesoproterozoico e do início do Neoproterozoico, são as formações Água Nova, Serra dos Macacos, Bairro dos Campos e Unidade Metabásica, sendo correspondentes à sequência basal de rochas metacarbonáticas e metapelitos de Siga Jr et al. (2009). A sequência de topo corresponde à Formação Abapã e é constituída por rochas metavulcanoclásticas, metarenitos arcoseanos e metapelitos do final do Neoproterozoico (Siga Jr et al. 2003).

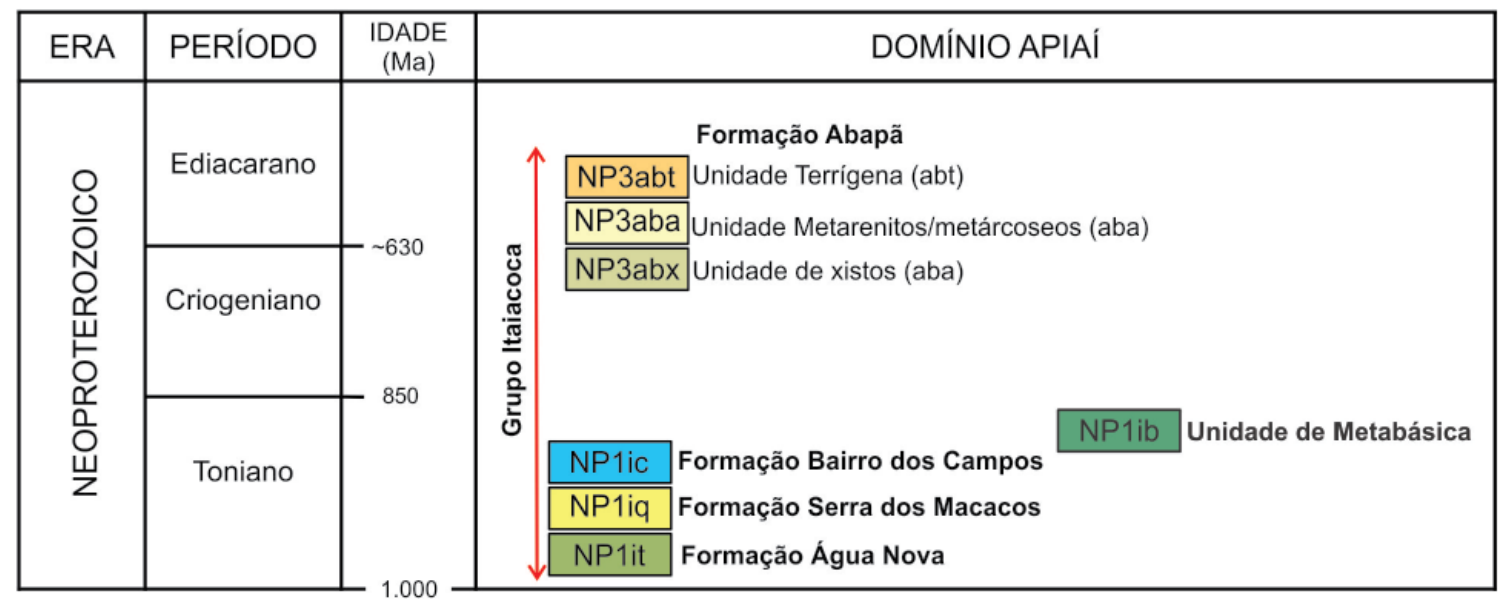

Figura 3-1: Coluna litoestratigráfica do Grupo Itaiacoca 


\subsubsection{Formação Água Nova (NP1it)}

A Formação Água Nova foi definida originalmente por Souza (1990), como uma sequência de rochas metapelíticas e metacarbonáticas, associadas a ambiente oceânico de plataforma continental. Em trabalhos anteriores de maior detalhe (escala 1:50.000), como de Bistrichi et al. (1985) e Theodorovicz et al. (1986), esta fomação é subdividida em diversas unidades, com critérios estratigráficos distintos e de difícil correlação regional.

É composta por uma sequência de rochas metassedimentares de origem terrígena com pequenas intercalações de metamargas e pacotes métricos de quartzitos finos. É representada principalmente por metarritmitos finos (ardósias e filitos) alternados com camadas milimétricas de metassiltito e camadas centimétricas de metarenito muito fino (fig. 3-2). Localmente são observados pacotes métricos de metarenitos, ocorrendo ainda corpos subordinados centimétricos de metaconglomerados oligomíticos (fig. 3-3). Neste litotipo é comum encontrar diversas estruturas preservadas, como laminação plano-paralela e dobras convolutas associadas a escorregamentos (slumps).

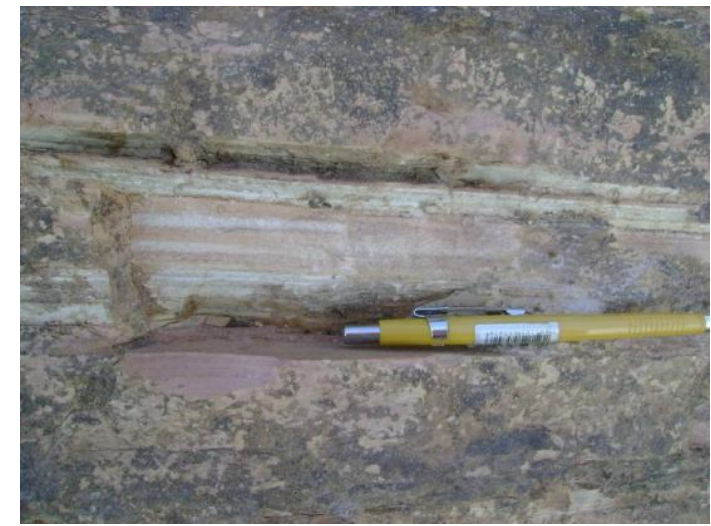

Figura 3-2: Foto de metarritmitos finos com intercalações centimétricas de níveis siltosos $e$ níveis de areia fina, caracterizando bandamento composicional contínuo (laminação planoparalela) da Formação Água Nova (NPlit). (Afloramento $S W$ - 16, SP-258 - 2,5 km a norte de Bom Sucesso de Itararé-SP)

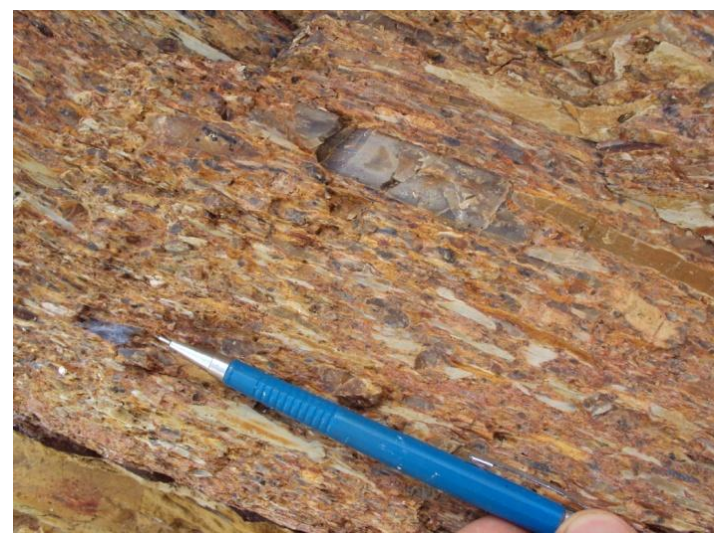

Figura 3-3: Foto da camada de metaconglomerado polimítico (seixos de calcário, siltitos e quartzitos) da Formação Água Nova Unidade Terrígena (NPlit). (Afloramento $S W-16$, SP-258 - 2,5 km a norte de Bom Sucesso de Itararé-SP)

\subsubsection{Formação Serra dos Macacos (NP1iq)}

A Formação Serra dos Macacos foi definida originalmente por Souza (1990), como uma sequência quartzítica, associada a ambiente praial (linha de costa).São corpos estreitos e 
alongados, amplamente distribuídos, que se destacam na paisagem, sustentando diversas serras. Comumente são encontrados intercalados nas Formações Água Nova (NP1it) e Bairro dos Campos (NPlic). Esta unidade é caracterizada por quartzitos e metarenitos de granulação fina a muito fina com textura granoblástica. Em geral apresentam um aspecto maciço (fig 3-4) e assemelham-se a veios de quartzo, porém levemente orientados quando em contato com outras litologias ou zonas de cisalhamento rúpteis e dúcteis, onde ocorrem termos cataclasados e miloníticos (fig. 3-5).

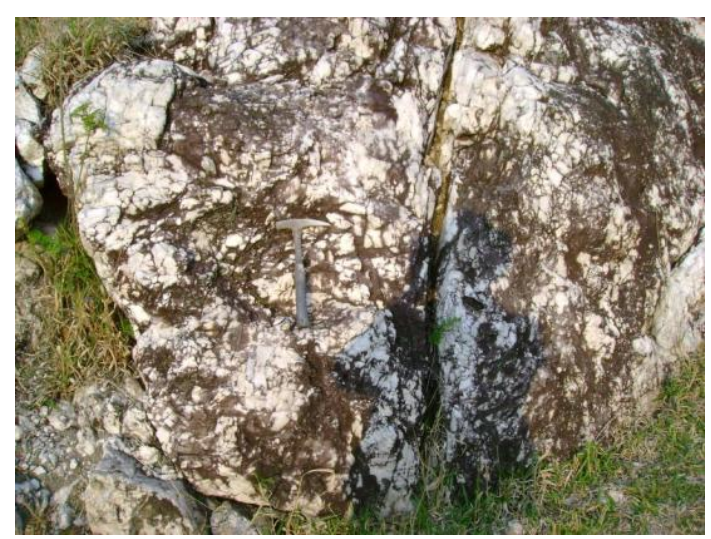

Figura 3-4: Foto de quartzitos/metarenitos de granulação fina a muito fina, cor branca, maciço $e$ intensamente fraturado da Formação Serra dos Macacos (NPliq). (Afloramento SW-136, Bairro das Almas, Bom Sucesso de Itararé-SP)

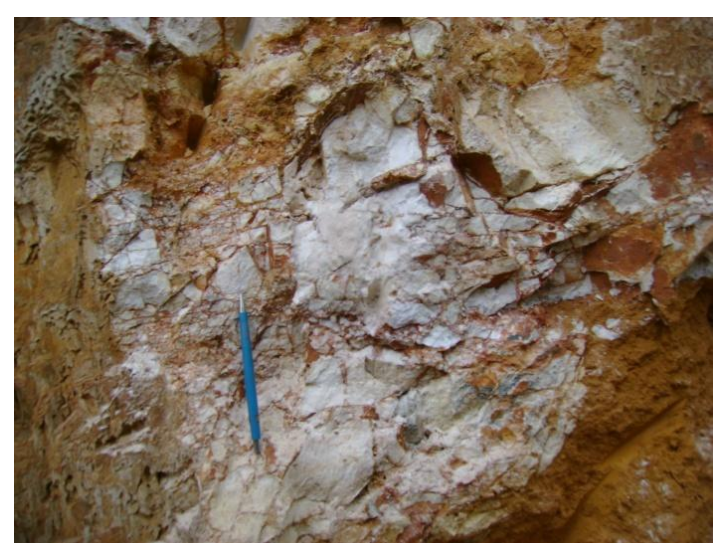

Figura 3-5: Foto de quartzitos/metarenitos de granulação fina a muito fina, cor branca, cataclasado/brechado da Formação Serra dos Macacos (NP1iq). (Afloramento SW- 711, Serra de Itapirapuã, Doutor Ulysses-PR)

\subsubsection{Formação Bairro dos Campos (NP1ic)}

A Formação Bairro dos Campos é definida por Souza (1990) como uma sequência de metacalcários e metadolomitos associados ao desenvolvimento de uma ampla plataforma carbonática. Esta unidade ficou conhecida pelos trabalhos pioneiros de Almeida (1944 e 1956), em que foram descritos o primeiro registro de estromatólitos no Brasil.

É constituída predominantemente por mármores dolomíticos com intercalações de metamargas, como filitos carbonáticos e calcifilitos. Nos mármores sua estrutura é geralmente maciça e homogênea, porém em alguns afloramentos é possível observar um bandamento com níveis de cor variada (branco, cinza, etc - fig 3-6) que sugerem uma provável estratificação sedimentar. Outras estruturas primárias também são observadas, tais como estromatólitos colunares (fig 3-7), marcas de ondulações, oólitos, pisólitos e estratificações cruzadas (fig 3$8)$. 
Na borda oeste da área de estudo o contato desta unidade com o granito Patrimônio Santo Antônio é caracterizado por um metamorfismo de contato, evidenciado em amostras provenientes da mina Cerrado da Roseira. Em lâmina os metadolomitos desta região apresentam uma matriz carbonática com textura granoblástica poligonizada (recristalização), assim como lentes e bolsões descontínuos com forsterita, tremolita, talco, diopsídio, quartzo, calcita metamórfica e serpentina. O mineral índice principal é a tremolita, encontrado frequentemente ao longo de fraturas ou em forma de porfiroblastos milimétricos isolados (fig. 3-9). Já os cristais de forsterita ocorrem disseminados e bastante alterados (serpentinizados) ou, em alguns casos, substituídos totalmente por serpentina (pseudomorfos de olivina). $\mathrm{O}$ talco é tido como mineral acessório e quase sempre substituindo a tremolita nas zonas de fratura.

Szabó et. al. (2006) estudaram as formas de ocorrência das jazidas de talco na região de Abapã e Socavão (PR) em relação aos eventos metamórficos dos metadolomitos do Grupo Itaiacoca. No caso do metamorfismo de contato e hidrotermal com a Suíte Intrusiva Cunhaporanga, os autores concluíram que o talco proveniente desta relação é de origem retrometamórfica e apresenta uma quantidade insuficiente para uma jazida. Além disso, destacam a dificuldade para traçar as isógradas em campo próximo do contato, tanto pela descontinuidade de exposições como pela blastese dos minerais índices estarem relacionadas a canais preferenciais seguidos pelos fluídos aquosos, principalmente em sistemas de fraturas e planos de acamamento.

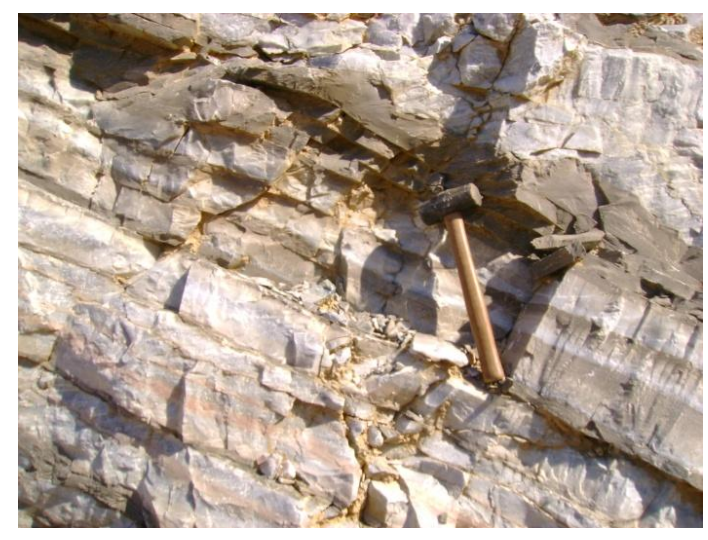

Figura 3-6: Foto de mármores bandados caracterizado por níveis de cor branca, cinza claro $e$ cinza escuro, da Formação Bairro dos Campos (NP1ic). (Afloramento SW- 303, Pedreira St. Antônio, Mineração S. Judas, Sengés-PR)

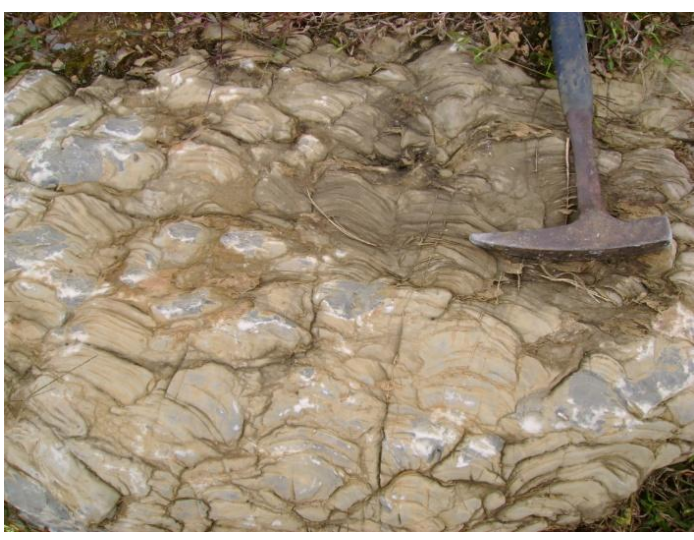

Figura 3-7: Foto das estruturas estromatóliticas (laminação cônica) em metacalcilutito da Formação Bairro dos Campos (NPlic). (Afloramento SW- 463, Bairro Palmeira de Cima, Sengés-PR) 


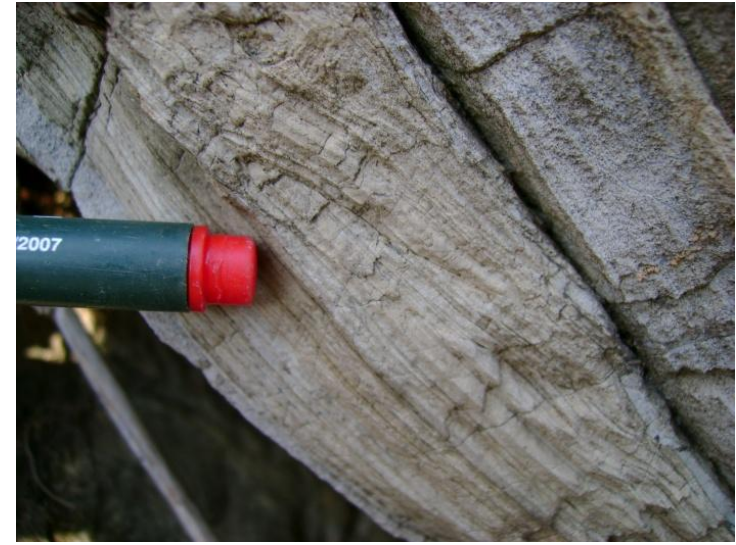

Figura 3-8: Foto de laminação cruzada em metacalcarenito da Formação Bairro dos Campos (NPlic). (Afloramento SW- 145, Bairro os Campos, Bom Sucesso de Itararé-SP)

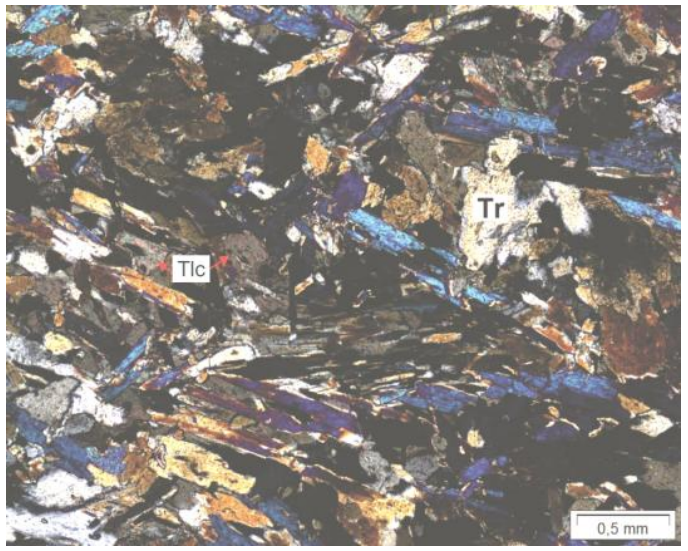

Figura 3-9: Fotomicrografia com nícois cruzados. Porfiroblastos de tremolita aciculares e orientados. Detalhe para o talco substituindo a tremolita (Afloramento localizado na mina Cerrado da Roseira)

\subsubsection{Unidade de Metabásica (NP1ib)}

Na área estudada, a Unidade metabásica é constituída por pequenos corpos mapeáveis de rochas metabásicas intercalados na Formação Água Nova. Os trabalhos de Theodorovicz et al. (1986) e Reis Neto (1994) descrevem rochas metabásicas muito similares às caracterizadas nesta unidade, porém intercaladas à Formação Bairro dos Campos. As principais ocorrências localizam-se no Bairro das Almas (Bom Sucesso de Itararé-SP) e no Bairro do Azedo (Itapirapuã Paulista-SP), sendo que apresentam orientação NE-SW.

As metabásicas caracterizam-se pela textura nematogranoblástica e inequigranular, granulação média, cor preta e composição gabroica a diorítica. A mineralogia principal é constituída por plagioclásio, hornblenda e biotita, apresentando como minerais acessórios mais comuns titanita, apatita, quartzo e minerais opacos.

Reis Neto (1994), na região de Abapã e Socavão (PR), descreveu rochas metabásicas com composição de basaltos subalcalinos e toleíticos, similares às descritas nesta unidade. $\mathrm{O}$ referido autor, a partir de diferentes métodos geocronológicos ( $\mathrm{Pb}-\mathrm{Pb}, \mathrm{Sm}-\mathrm{Nd}$ e $\mathrm{Rb}-\mathrm{Sr}$ ), indica idades do final do Mesoproterozoico ( 1000 Ma) para o magmatismo associado a estas rochas. Análises geocronológicas U-Pb (SHRIMP e TIMS) realizadas por Siga Jr et al. (2009) em zircões das rochas metabásicas, na região de Abapã e Socavão (PR) forneceram idades de cristalização entre 1030-908 Ma. 


\subsubsection{Formação Abapã (NP3ab)}

A Formação Abapã corresponde a sequência superior do Grupo Itaiacoca e é representada por uma associação de rochas metassedimentares com intercalações metavulcânicas e metavulcanoclásticas. Nesta dissertação a Formação Abapã é divida em três unidades: Unidade de xistos (NP3abx), Unidade de metarenitos e metarcóseos (NP3aba) e Unidade Terrígena (NP3abt).

A Unidade de xistos (NP3abx) é constituída por xistos e filitos feldspáticos (metawackes) bandados (figs. 3-10 e 3-11), com granulometria fina a muito fina, textura lepidoblástica e cor cinza escuro. O bandamento é composto pela alternância de metarenitos finos com metassiltitos.

A Unidade de metarenitos e metarcóseos (NP3aba) é caracterizada por metarenitos puros (quartzitos) e impuros (metarcóseos e metarenitos feldspáticos). São rochas com coloração esbranquiçada, granulometria média a grossa e textura granoblástica. Ocasionalmente ocorrem pacotes de metarenito rítmico com estruturas primárias preservadas (figs. 3-12 e 3-13), como estratificações cruzadas e laminação plano-paralela. Ainda nesta unidade, Soares et al. (1987) descrevem a ocorrência de metavulcânicas básicas junto aos metarenitos arcoseanos. Siga Jr. et al. (2003) apresentou datações de U-Pb em zircões destas rochas metavulcânicas na região de Abapã e Socavão (PR) e obteve idades entre 645 a 628 Ma.

A Unidade terrígena (NP3abt) é composta por filitos e ardósias com textura granolepidoblástica, granulometria muito fina e bandamento composicional milimétrico. 


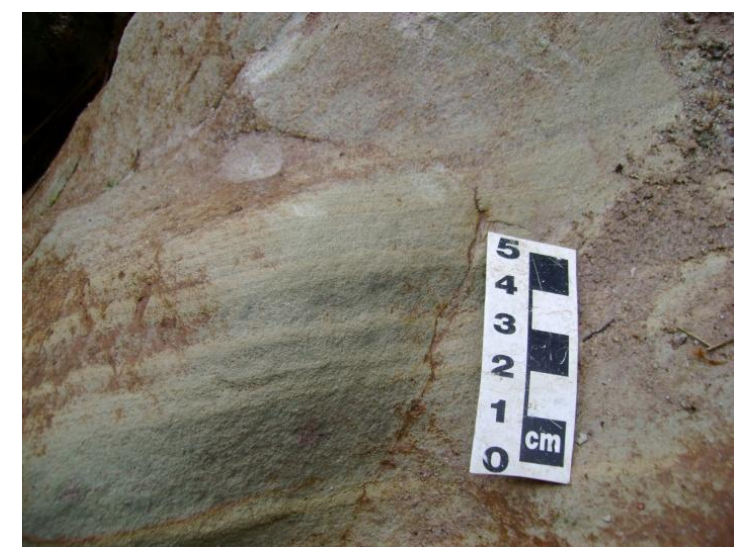

Figura 3-10: Foto de filito/xisto feldspáticos bandados (metawackes) da Unidade de xisto da Formação Abapã (NP3abx). (Afloramento SW-677, Bairro da Estiva, Sengés-PR)

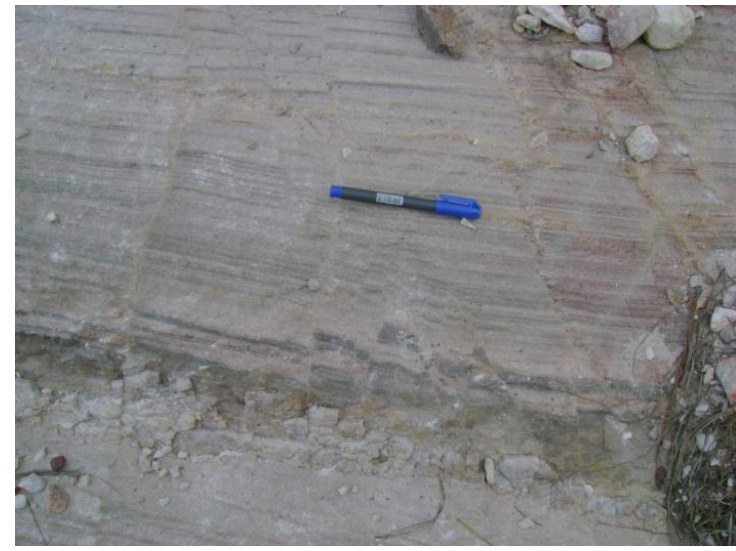

Figura 3-12: Foto do metarenito rítmico (bandado) com intercalações milimétricas a sub-centimétricas de níveis micáceos afetados por pequenas falhas rúpteis. Unidade de metarenitos/metarcóseos da Formação Abapã (NP3aba). (Afloramento SW-336, Serra das Antas, Sengés-PR)

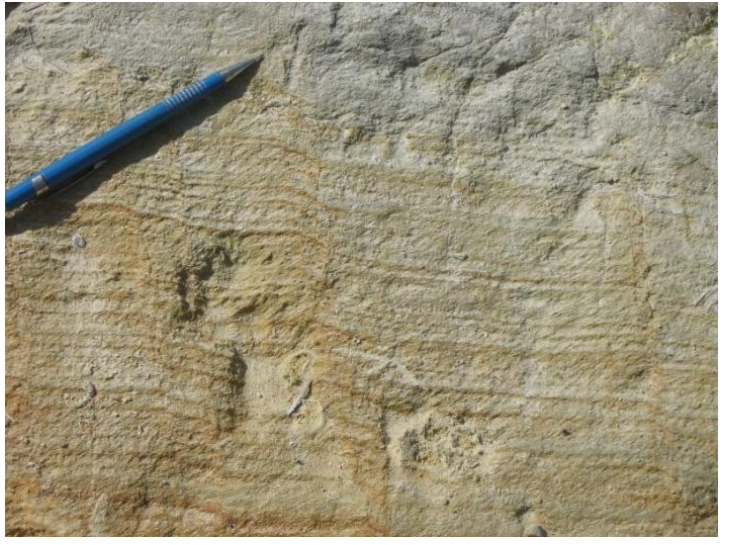

Figura 3-11: Foto de filito/xisto feldspáticos bandados (metawackes) da Unidade de xisto da Formação Abapã (NP3abx). (Afloramento SW- 676, Bairro da Estiva, Sengés-PR)

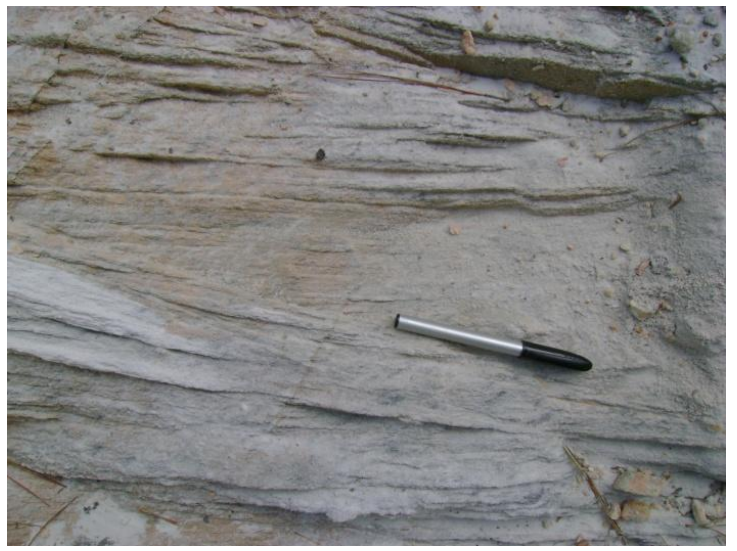

Figura 3-13: Foto de metarenito feldspático estratificação da Unidade de metarenitos/metarcóseos da Formação Abapã (NP3aba). (Afloramento SW-347, Serra das Antas, Sengés-PR) 


\subsection{Suíte Intrusiva Cunhaporanga}

A Suíte Intrusiva Cunhaporanga aflora em uma faixa de cerca de $30 \mathrm{~km}$ de largura e direção NE-SW, ocupando uma área de aproximadamente $3700 \mathrm{Km}^{2}$ desde a região de Ponta Grossa (PR) até a região de Doutor Ulysses (PR).

Estudos pioneiros foram realizados por Oliveira (1916, 1927), Bigarella (1947) e Almeida (1956). A partir do final da década de 60 e início da década de 70 começam mapeamentos sistemáticos realizados pela Comissão da Carta Geológica do Paraná (CCGP) e pela Companhia de Pesquisa de Recursos Minerais (CPRM), sendo destacados os seguintes trabalhos: Fuck et al. (1967), Algarte et al. (1972) e Batolla Júnior et al. (1977). A partir da década de 80, destacam-se os estudos conduzidos pela Minerais do Paraná S.A. (MINEROPAR): Ribas (1981), Biondi et al. (1989), entre outros.

Conforme Prazeres Filho (2005), a unidade é no geral constituída por monzo a sienogranitos de coloração rósea a cinza e subordinadamente por granodioritos e quartzomonzonitos. Ocorrem ainda corpos subvulcânicos, de composição álcali-feldspato granítica e intrusivos, a exemplo dos Granitos Carambé e Joaquim Murtinho. Descrições petrográficas são apresentadas nos trabalhos de Fuck et al. (1967), Algarte et al. (1972), Santos e Felipe (1980), Wernik et al. (1990), Guimarães (1995 e 2000) e Prazeres Filho (2000 e 2005).

Guimarães (2000), a partir de dados geoquímicos e petrográficos, sugere duas associações principais de rochas graníticas. A predominante é constituída por granitos de caratér cálcio-alcalinos de alto $\mathrm{K}$, com afinidades shoshoníticas e associadas à tipologia I a Granitos “tipo I", (White e Chappell ,1983 e Barbarin, 1990). A outra série é caracterizada por álcali-felspato granitos (alasquítico) muito semelhantes a granitos do "tipo A" (Granitos anorogênicos,; White e Chappell,1983 e Barbarin, 1990).

A Suíte Intrusiva Cunhaporanga apresenta um grande conjunto de dados geocronológicos de idades U-Pb (TIMS e SHRIMP) em zircões que variam no intervalo de 650 a 590 Ma (Prazeres Filho, 2000 e 2005). Este conjunto de idades também foi observado obtido a partir de outros métodos geocronológicos, como K-Ar (biotita e rocha total) e Rb-Sr (rocha total), apresentadas nos trabalhos de Reis Neto (1994) e Prazeres Filho (2000).

$\mathrm{Na}$ área de estudo, a Suíte Intrusiva Cunhaporanga foi dividida em quatro unidades que são individualizadas por apresentarem diferentes aspectos composicionais, texturais e

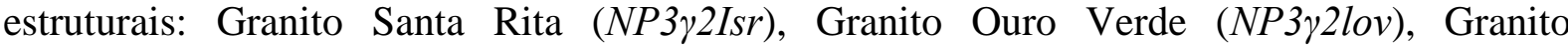




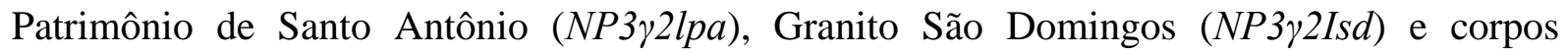
graníticos indiferenciados $(N P 3 \gamma 2 l t)$.

\subsubsection{Granito Santa Rita (NP3p $\gamma 2$ Isr)}

O termo Granito Santa Rita equivale aos termos: Domínio Santa Rita (NPcsr), de Guimarães (2000), e à Unidade Santa Rita-Vila Branca, de Prazeres Filho (2005).

O Granito Santa Rita (fig.3.14) está localizado na porção sudoeste da área de estudo e abrange uma área aproximada de $60 \mathrm{~km}^{2}$. O plúton é delimitado ao norte por contato tectônico por zona de cisalhamento com o Granito Patrimônio Santo Antônio (NP3py2Isa), e por rochas metassedimentares milonitizadas da Formação Abapã. Já na borda leste é separado por um contato intrusivo com as rochas metassedimentares da Unidade de Xisto da Formação Abapã.

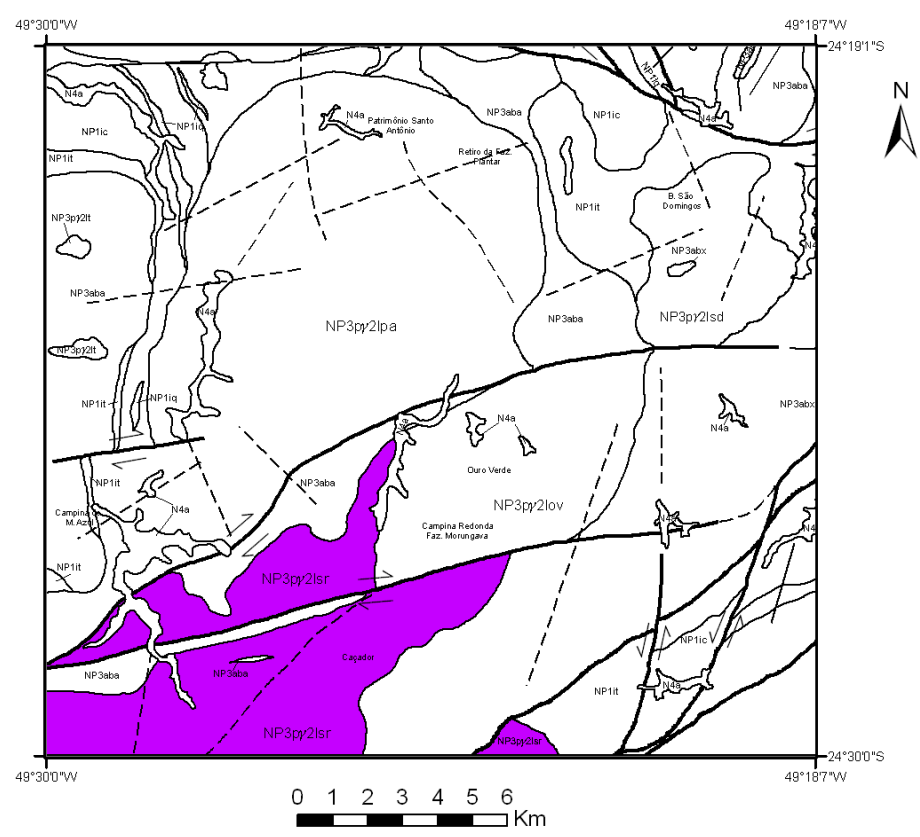

Figura 3-14: Granito Santa Rita (NP3p $\gamma 2$ Isr)

Nesta unidade o litotipo principal é um biotita monzogranito (fig. 3-15), cor cinza claro a róseo, leucocrático (índice de cor varia entre 7 a 15\%), foliado e com textura fanerítica média a porfirítica. Em geral os cristais de biotita estão quase sempre orientados, sendo que em alguns afloramentos é possível identificar esta trama também nos fenocristais de feldspato potássico e quartzo. Outra característica é a abundância de vênulas e veios aplíticos quartzofeldspáticos distribuídos em toda sua extensão, assim como enclaves microgranulares orientados com a trama principal. 
Próximo à zona de cisalhamento aflora uma fácies muito semelhante à observada no Granito São Domingos (NP3py2Isd). Trata-se de um sienogranito (fig. 3-16), cor rósea, textura fanerítica grossa e com muitas fraturas, estas apresentando um padrão ortogonal entre si e preenchidas por fluorita e quartzo. Estas mesmas características também são encontradas em outro afloramento, ao norte do Granito Patrimônio Santo Antônio.

$\mathrm{Na}$ descrição microscópica este granito róseo possui textura cataclástica e hipidiomórfica inequigranular. As microfraturas encontram-se preenchidas em grande parte por fluorita (fig. 3-17) e em menores proporções por leitos com quartzo recristalizado, desenvolvidos tanto pelo processo de migração de borda como pelo tipo "bulging" (fig. 3-18). Os cristais de plagioclásio (oligoclásio) também estão fraturados e saussuritizados e a biotita quase totalmente substituída pela clorita. Já os outros minerais acessórios, como titanita euédrica, allanita, apatita e zircão ocorrem frequentemente associados à clorita.

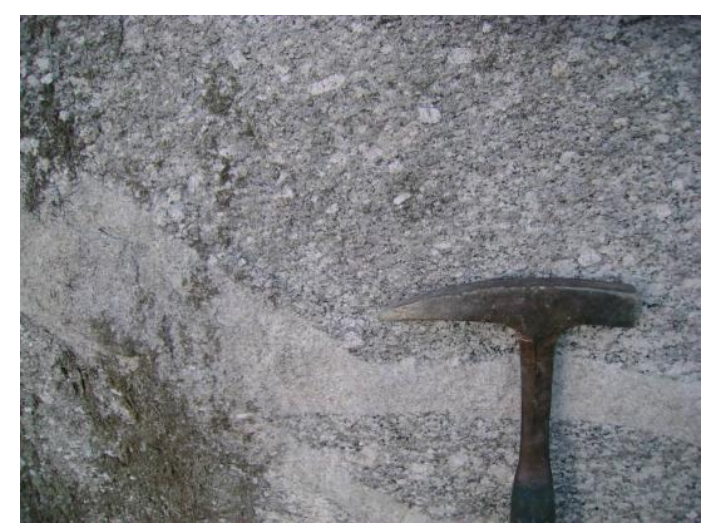

Figura 3-15: Biotita granito porfirítico de cor cinza, do Granito Santa Rita (NP3 2 2lsr) intercalado com fácies aplítica (Afloramento localizado na estação de ASM 56, Caçador, Doutor Ulysses-PR)

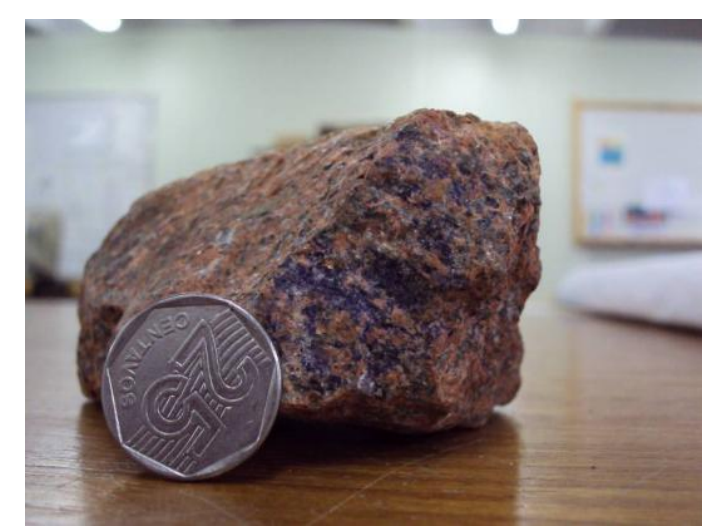

Figura 3-16: Biotita sienogranito fanerítico de cor vermelha com veios de fluorita (cor roxa) do Granito Santa Rita (NP3r2lsr). (Afloramento localizado na estação de ASM 55, Caçador, Doutor Ulysses-PR)

Prazeres Filho (2000 e 2005), analisando biotita monzogranitos, próximo a região de Abapã, obteve as seguintes idades: $480 \pm 11 \mathrm{Ma}$ (K-Ar, biotita), $588 \pm 70 \mathrm{Ma}$ (U-Pb, IDTIMS, zircão) e $626 \pm 8 \mathrm{Ma}$ (U-Pb, SHRIMP, zircão), sendo esta última utilizada pelo referido autor para caracterizar o período de cristalização desta unidade. 


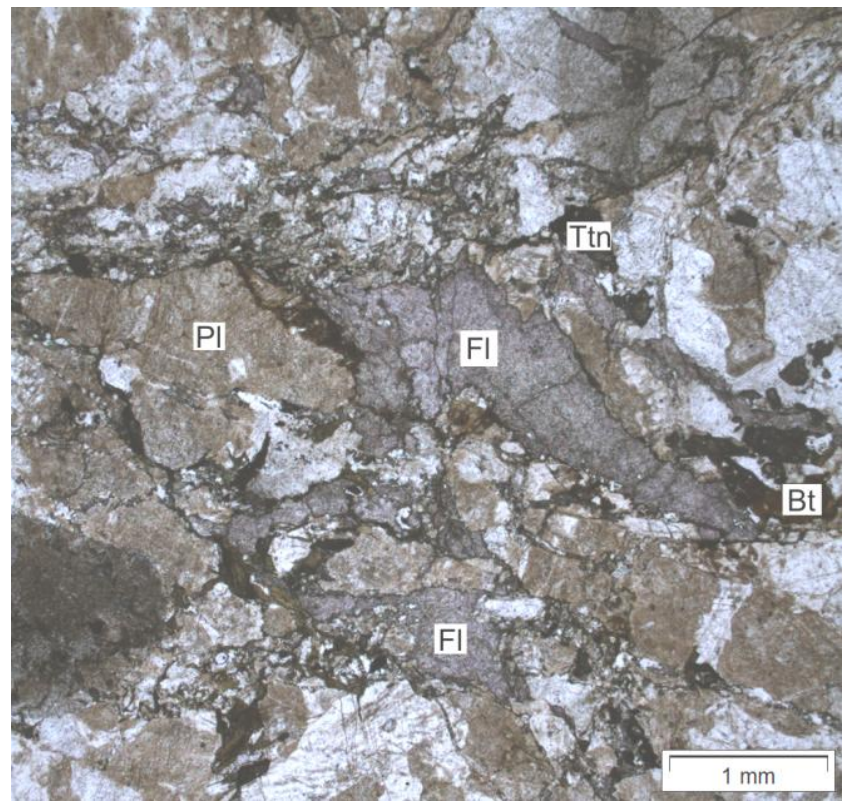

Figura 3-17: Fotomicrografia do sienogranito. Detalhe da fluorita preenchendo as microfraturas (Afloramento localizado na estação de ASM 54)

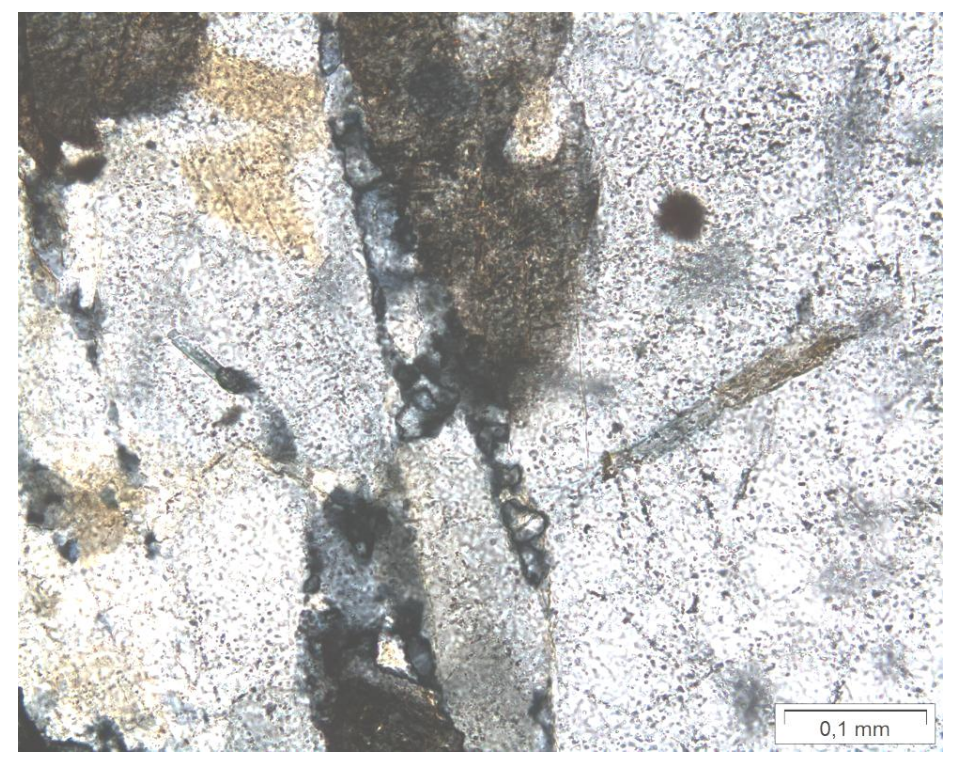

Figura 3-18: Fotomicrografia do sienogranito. Detalhe da recristalização dinâmica do quartzo pelo mecanismo de "bulging” na borda do plagiclásio (Afloramento localizado na estação de ASM 54) 


\subsubsection{Granito Ouro Verde (NP3py2Iov)}

A designação "Ouro Verde-Patrimônio" como fácies da Suíte Intrusiva Cunhaporanga é utilizado por Guimarães (2000) e Prazeres Filho (2005) para designar a série de rochas graníticas que afloram nas localidades de Patrimônio de Santo Antônio e Ouro Verde (município de Sengés-PR). Guimarães (2000) destaca a assinatura geofísica em mapas aerogamaespectrométricos (principalmente na composição Ternária). Neste trabalho, o termo "Ouro Verde-Patrimônio" foi desmembrado para caracterizar dois corpos diferenciados: Granito Ouro Verde e Granito Patrimônio Santo Antônio.

O Granito Ouro Verde (fig. 3-19) aflora na localidade homônima, sendo delimitado por zonas de cisalhamento ENE-WSW e contatos intrusivos com as rochas metassedimentares do Grupo Itaiacoca. O plúton possui uma forma elíptica e recobre uma área aproximada de 45 $\mathrm{km}^{2}$, localizado entre o distrito de Ouro Verde e a Fazenda Morungava (município de SengésPR). A unidade é representada principalmente por biotita monzogranito a sienogranito com textura fanerítica fina a grossa.

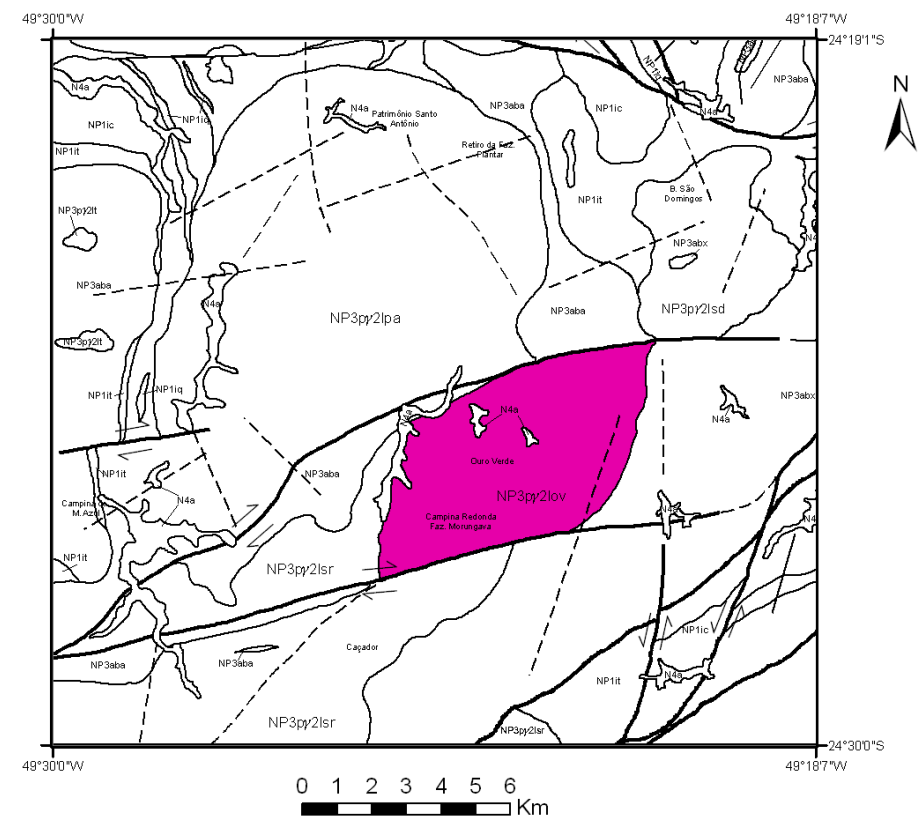

Figura 3-19: Granito Ouro Verde (NP3p 2 Iov)

A rocha é caracterizada por um biotita granito fanerítico de granulação média a fina (fig. 3-20), equigranular, leucocrático (índice de cor varia entre 5 a 10\%) com estrutura maciça e alteração bem acentuada, especialmente no plagioclásio e o feldspato potássico. $\mathrm{O}$ 
mineral máfico principal é a biotita e secundariamente o anfibólio. Localmente encontram-se enclaves microgranulares com composição distinta nas bordas do granito.

Em lâmina o enclave microgranular possui uma textura hipidiomórfica e uma grande proporção de biotita e muscovita, que formam leitos milimétricos (fig. 3-21) alternados com bandas de quartzo, plagioclásio e feldspato potássico (microclínio). Os cristais de quartzo encontram-se na forma de sub-grãos alongados e com contatos lobados, desenvolvidos pela recristalização por migração de borda (fig. 3-22).

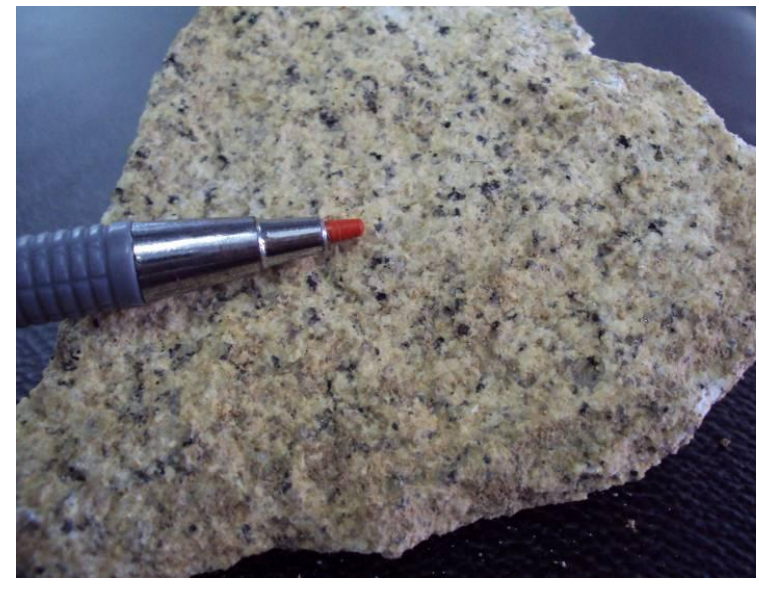

Figura 3-20: Foto do biotita granito fanerítico leucocrático de cor branca, do Granito Ouro Verde (NP3y2lov). (Afloramento localizado na estação de ASM 23, Ouro Verde, Sengés-PR)

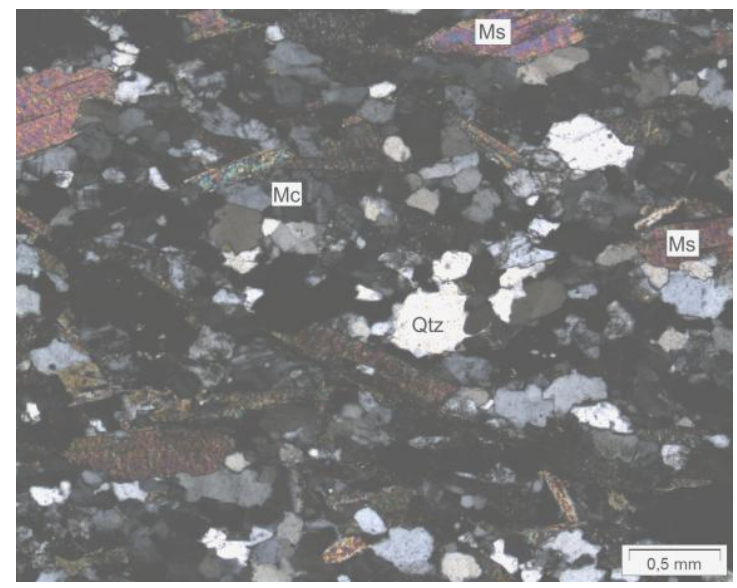

Figura 3-22: Fotomicrografia com nicóis cruzados do enclave microgranular. Cristais de quartzo recristalizados pelo processo de migração de borda (Afloramento localizado na estação de ASM 23, Ouro Verde, Sengés-PR)

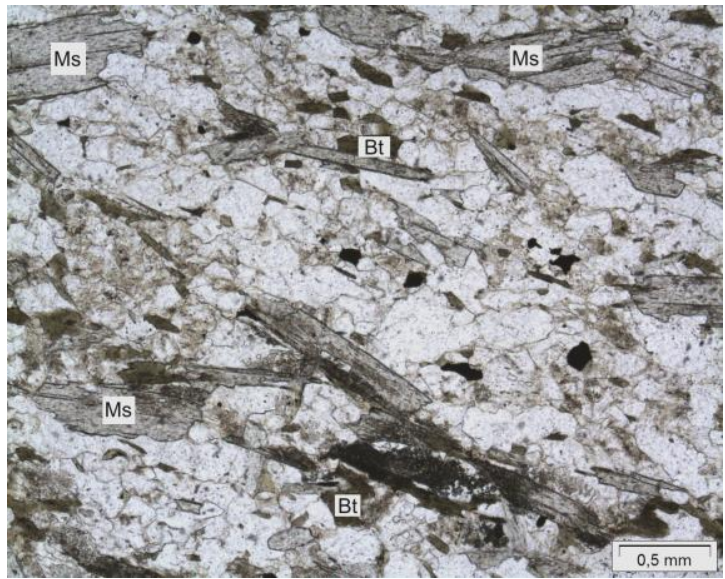

Figura 3-21: Fotomicrografia do enclave microgranular. Leitos de biotita e muscovita alternados com bandas de quartzo e feldspato (Afloramento localizado na estação de ASM 23, Ouro Verde, Sengés-PR) 


\subsubsection{Granito Patrimônio Santo Antônio (NP3py2Ipa)}

Com dimensão de cerca de $100 \mathrm{~km}^{2}$, o Granito Patrimônio Santo Antônio representa o principal granito estudado nesta dissertação. Apresenta uma forma em gota e contatos intrusivos com rochas metassedimentares do Grupo Itaiacoca a norte e tectônicos com zonas de cisalhamento ENE-WSW a sul. Ele ocupa a porção oeste da área e está situado entre os bairros Patrimônio Santo Antônio, Campina do Morro Azul, Roseira e a Fazenda Morungava (fig.3-23).

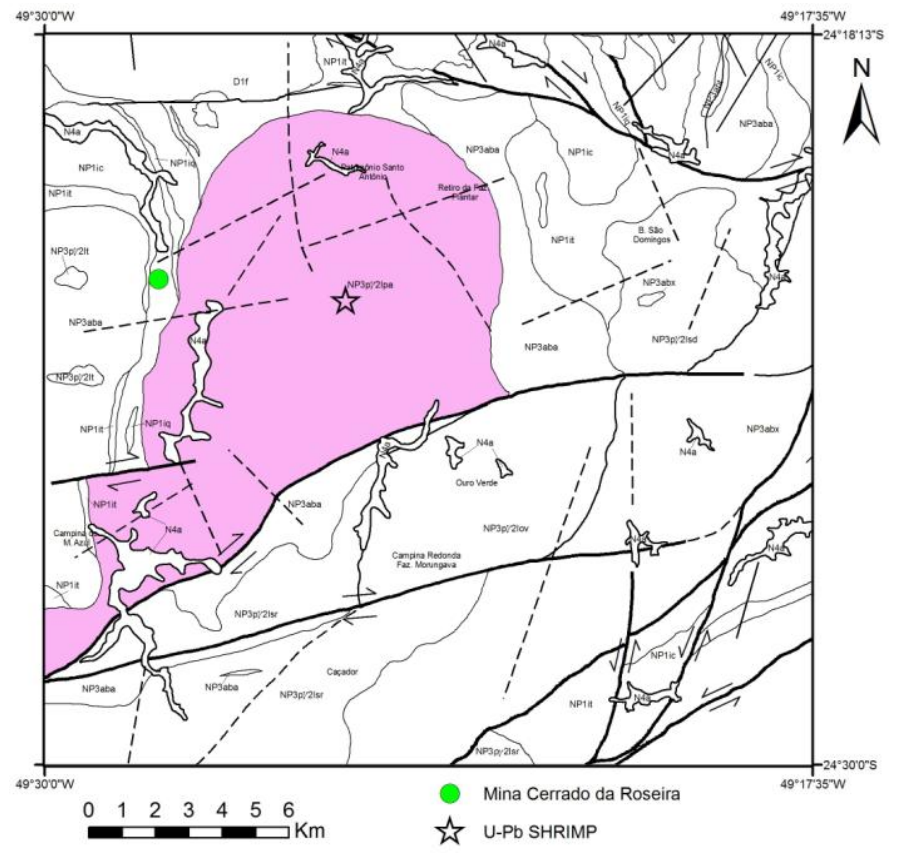

Figura 3-23: Granito Patrimônio Santo Antônio (NP3p 2 Ipa)

O maciço está exposto na forma de matacões de tamanho decamétrico a métrico espalhados em áreas intensamente reflorestadas com pinus e eucalipto (fig. 3-24). O granito possui uma composição que varia de biotita monzogranito a sienogranito porfirítico. Localmente, e notadamente na periferia do maciço, ocorrem fácies de sienogranitos equigranulares finos a médios.

O Granito Patrimônio Santo Antônio possui cor rosa claro e sua textura varia de isótropa (maciça) a seriada, com a granulação da matriz podendo variar de grossa (fig. 3-25) a média (fig. 3-26). Os fenocristais de feldspato potássico róseo $(1-4 \mathrm{~cm})$ e plagioclásio $(0,5-$ $1,5 \mathrm{~cm}$ ) são idiomórficos, e muitas vezes podem apresentar textura rapakivi e anti-rapakivi, bem como inclusões de biotita. Localmente o quartzo possui forma globular, principalmente 
na matriz de granulação grossa. O índice de cor é leucocrático, geralmente entre 10 e 15\%, e seus minerais máficos são biotita e titanita com hábitos euédricos.

Outra fácies deste granito é caracterizada por um sienogranito fanerítico de cor vermelha a rosa clara (fig. 3-27), granulação grossa a média, inequigranular e hololeucocrático a leucocrático (M 10\%). Em seção delgada são observados como minerais principais feldspato potássico, plagioclásio, quartzo e biotita, sendo que titanita, sericita e zircão ocorrem como minerais acessórios.

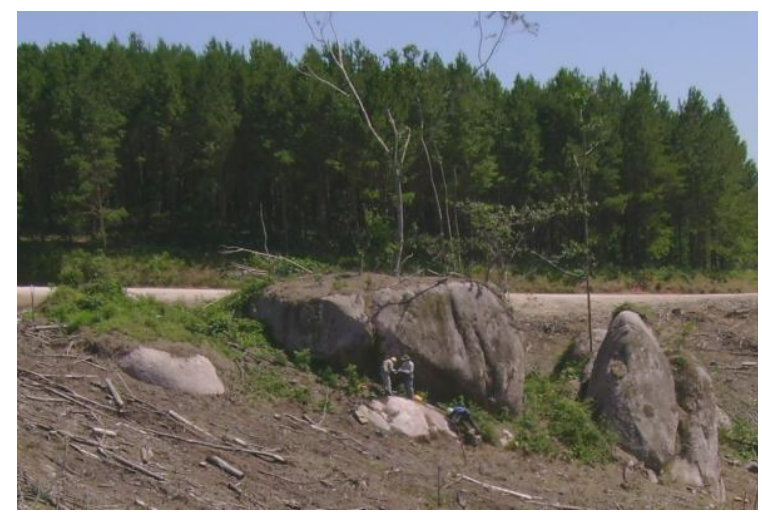

Figura 3-24: Foto do afloramento típico observado no Granito Patrimônio de Santo Antônio (NP3r2lpa), com grandes matacões e pequenas lajes (Afloramento localizado na estação de ASM 3, Patrimônio de Santo Antônio, Sengés-PR)

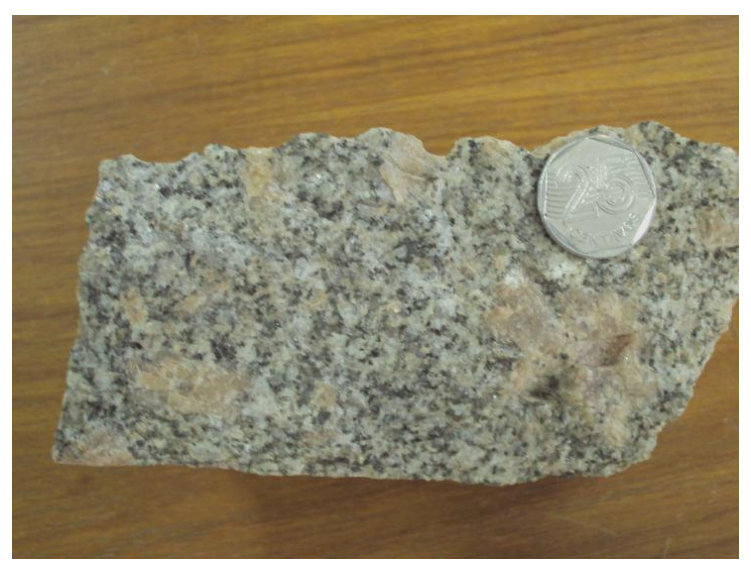

Figura 3-26: Foto do biotita granito porfirítico, com matriz de granulação média, leucocrático e cor branca a rosa clara do Granito Patrimônio Santo Antônio (NP3r2lpa). (Afloramento localizado na estação de ASM 48, Caçador, Doutor Ulysses-PR)

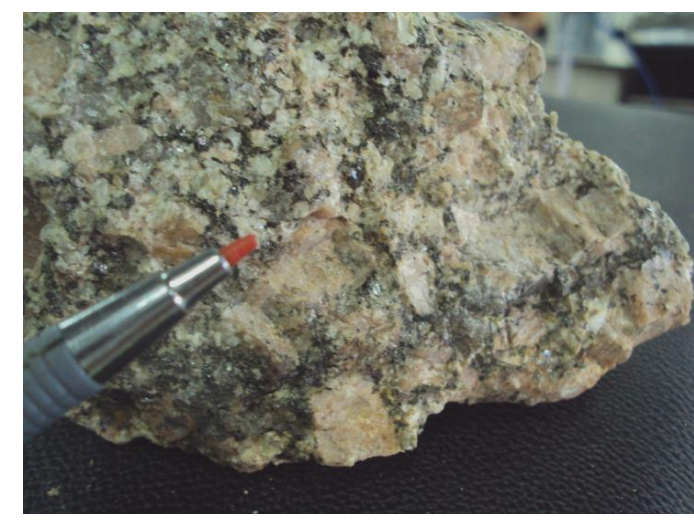

Figura 3-25: Foto do biotita granito porfirítico com matriz de granulação grossa com fenocristais idiomórficos de K-feldspato. (Afloramento localizado na estação de ASM 26, Caçador, Doutor Ulysses-PR)

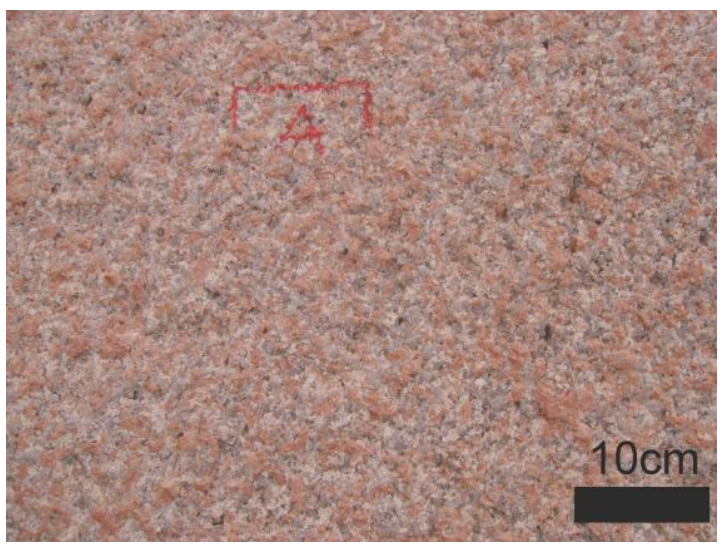

Figura 3-27: Foto do biotita granito fanerítico, hololeucocrático, cor vermelha a rosa clara $e$ granulação grossa do Granito Patrimônio Santo Antônio (NP3r2lpa). (Afloramento localizado na estação de ASM 10, $2 \mathrm{~km}$ a leste de Patrimônio de Santo Antônio, Sengés-PR) 
Em lâmina tanto os monzogranitos como sienogranitos exibem uma textura hipidiomórfica granular contendo fenocristais de plagioclásio e feldspato potássico. $\mathrm{O}$ plagioclásio é idiomórfico a subidiomórfico, e localmente apresenta-se zonado (fig. 3-28). O feldspato potássico pode conter lamelas de exsolução de albita (pertita) e, nas bordas, intercrescimento com quartzo (mirmequita) (fig. 3-29). A biotita comumente encontra-se intercrescida com a clorita e, assim como na titanita, está associada com minerais opacos. Os minerais acessórios principais são allanita, apatita e zircão.

Minerais secundários são comumente encontrados no plagioclásio e, de forma mais restrita, no feldspato potássico. O plagioclásio está sericitizado e saussuritizado, sendo comum encontrar em lâmina pseudomorfos de plagioclásio totalmente substituído por sericita.

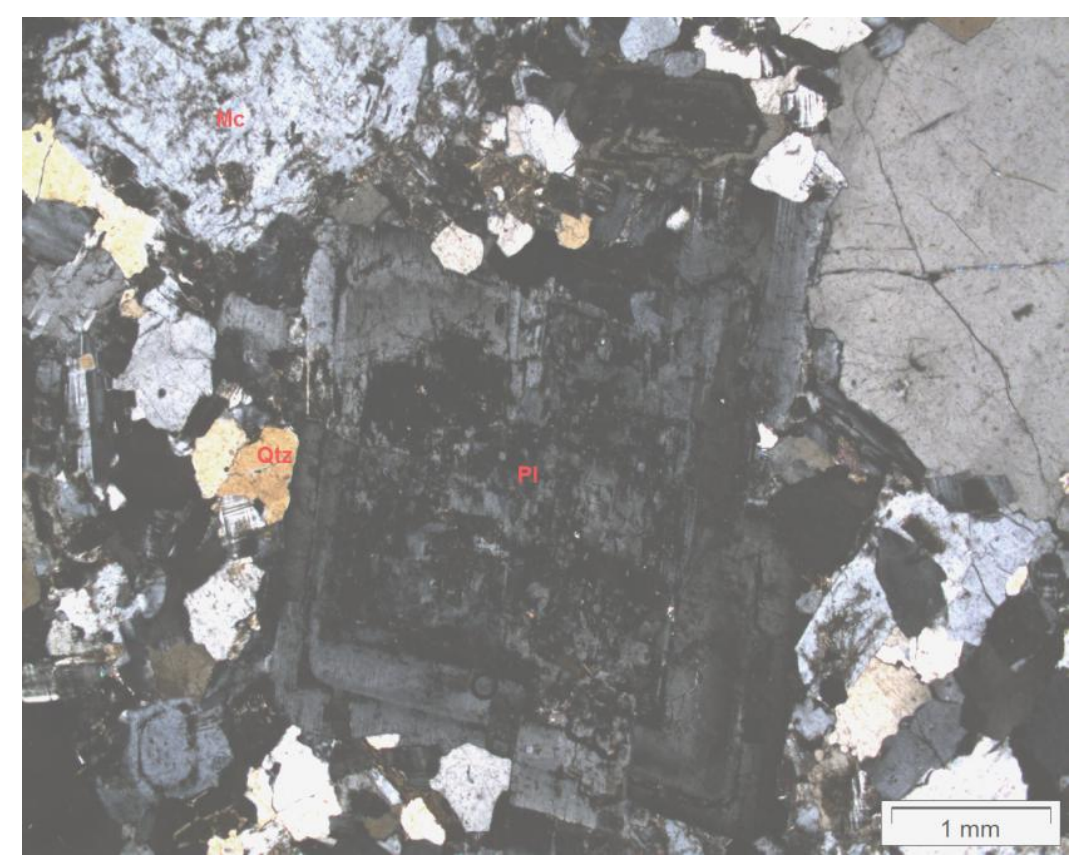

Figura 3-28: Fotomicrografia do biotita monzogranito porfirítico. Cristal de plagioclásio zonado, com extinção do núcleo para a borda (Afloramento localizado na estação de ASM 17) 


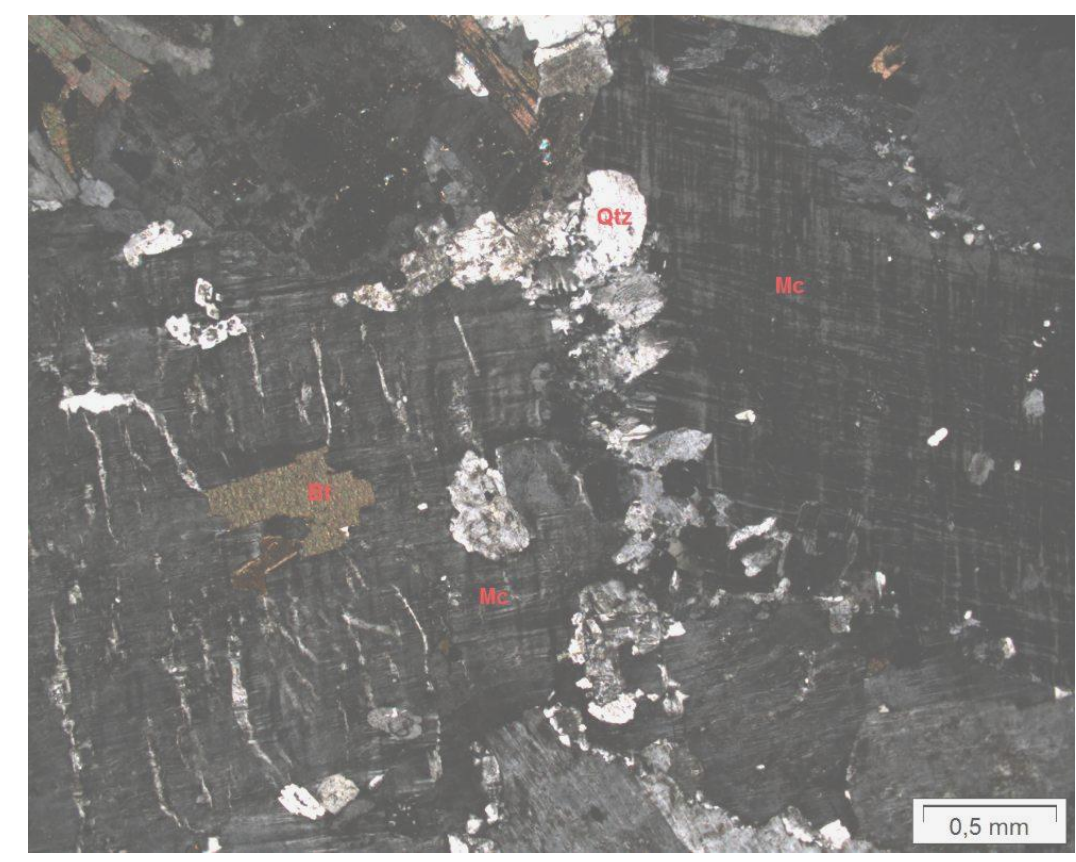

Figura 3-29: Fotomicrografia do biotita monzogranito porfirítico. Cristal de microclínio com textura de micropertita (Afloramento localizado na estação de ASM 48)

As relações de contato do granito com as rochas metassedimentares encaixantes foram observadas na mina Cerrado da Roseira, situada na porção oeste da intrusão, conforme já descrito anteriormente, sendo observados hornfels e minerais indicativos de metamorfismo de contato.

\subsubsection{Geocronologia (U-Pb SHRIMP)}

Como principal corpo granítico estudado neste trabalho foi realizada uma datação geocronológica utilizando uma microssonda iônica de alta resolução (SHRIMP). Os zircões foram extraídos de uma amostra localizada na porção central do corpo, distante de falhas e fraturas (fig. 3-23). Trata-se de um biotita monzogranito porfirítico (amostra SW-304), representante da principal fácies mapeada.

Após a coleta de campo, a amostra foi encaminhada para o laboratório de preparação no Centro de Pesquisas Geocronológicas da USP (CPGeo-USP). Primeiramente a amostra foi triturada com o auxilio do britador de mandíbula e o quarteador de amostras para a separação em fragmentos menores. Em seguida estes fragmentos passaram por um conjunto de peneiras até se obter uma fração fina $(0,125-0,250 \mathrm{~mm})$, que foi condicionada ao separador 
magnético Frantz para isolamento da fração não magnética. Por fim, os cristais de zircão foram separados manualmente com o auxilio de uma lupa binocular e um microscópio petrográfico. Os zircões variam de 100 a $300 \mu \mathrm{m}$ de comprimento e ocorrem como prismas alongados com razão comprimento:largura (c:1) comumente entre 3:1 e 5:1. Alguns primas mais alongados podem exibir uma razão c:1 da ordem de 10:1, enquanto alguns poucos grãos mais curtos situam-se em torno de 2:1. A catodoluminescência (CL) mostrou que os zircões apresentam um marcante zoneamento magmático, de onde foram extraídos os dados isotópicos para determinação da idade de cristalização magmática, sem a presença aparente de núcleos herdados (fig. 3-30). Tanto a CL como as datações isotópicas de U-Pb pelo SHRIMP II foram realizadas através de uma conexão remota entre o Centro de Pesquisas Geocronológicas da USP (CPGeo-USP) e o Beijing SHRIMP Center, localizado em Beijing na China. A cada 3 pontos analisados, o equipamento passava por um procedimento de calibração com um zircão de referência TEM (417 Ma). O chumbo comum em todas as amostras foi corrigido utilizando o valor medido do ${ }^{204} \mathrm{~Pb}$. Os dados isotópicos foram tratados pelo software ISOPLOT de Ludwig (2001) seguindo os procedimentos analíticos presentes em Compston et al. (1992).

Os resultados provenientes dos dados isotópicos dos quinze diferentes cristais de zircão estão indicados na Tabela 1. Duas análises fortemente discordantes (2.1 e 7.1), uma análise com baixo teor de U (4.1) e duas análises embora pouco discordantes, com idade ${ }^{206} \mathrm{~Pb} /{ }^{238} \mathrm{U}$ muito antiga (10.1) e muito jovem (11.1) foram excluídas do cálculo. As dez análises restantes foram plotadas em um diagrama de Wetherill (fig. 3.31) para fornecer uma idade concórdia de $588.7 \pm 6.5 \mathrm{Ma}(\mathrm{MSWD}=0,38)$ e também agrupam-se para fornecer uma idade média 206Pb/238U de $589 \pm 6.4 \mathrm{Ma}(\mathrm{MSDW}=0,80)$, semelhante à idade concórdia. 
Tabela 1 - Dados analíticos dos cristais de zircão do Granito Patrimônio Santo Antônio.

Razões radiogenicas (1)

Idade (1)

\begin{tabular}{|c|c|c|c|c|c|c|c|c|c|c|c|c|c|c|}
\hline Analise & $\mathrm{U}(\mathrm{ppm})$ & $\mathrm{Th}(\mathrm{ppm})$ & $\mathrm{Th} / \mathrm{U}$ & ${ }^{206} \mathrm{~Pb} *(\mathrm{ppm})$ & ${ }^{206} \mathrm{~Pb}_{\mathrm{c}}(\%)$ & ${ }^{207} \mathrm{~Pb} * /{ }^{235} \mathrm{U}$ & $\pm \%$ & ${ }^{206} \mathrm{~Pb}^{*} /{ }^{238} \mathrm{U}$ & $\pm \%$ & \multicolumn{2}{|c|}{${ }^{206} \mathrm{~Pb} /{ }^{238} \mathrm{U}$} & \multicolumn{2}{|c|}{${ }^{207} \mathrm{~Pb} /{ }^{206} \mathrm{~Pb}$} & $\begin{array}{c}\% \\
\text { Dis- } \\
\text { cor- } \\
\text { dancia }\end{array}$ \\
\hline 1.1 & 110 & 168 & 1,58 & 9,46 & 1,13 & 0,862 & 5,4 & 0,0993 & 1,9 & 611 & \pm 11 & 705 & \pm 110 & 13 \\
\hline 2.1 & 160 & 139 & 0,90 & 13,40 & 1,69 & 0,734 & 6,4 & 0,0962 & 1,8 & 592 & \pm 10 & 426 & \pm 140 & -39 \\
\hline 3.1 & 236 & 296 & 1,30 & 20,00 & 1,20 & 0,785 & 4,8 & 0,0976 & 1,7 & 600,6 & $\pm 9,7$ & 540 & \pm 99 & -11 \\
\hline $3.1 \mathrm{r}$ & 204 & 232 & 1,17 & 16,70 & 1,60 & 0,741 & 6 & 0,0938 & 1,7 & 578 & $\pm 9,5$ & 501 & \pm 130 & -15 \\
\hline 4.1 & 97 & 61 & 0,65 & 8,64 & 3,48 & 0,810 & 18,0 & 0,1002 & 2,3 & 616 & \pm 14 & 565 & \pm 400 & -9 \\
\hline 5.1 & 310 & 307 & 1,02 & 25,30 & 0,99 & 0,75 & 4,5 & 0,0941 & 1,8 & 579,6 & $\pm 9,8$ & 522 & \pm 91 & -11 \\
\hline 6.1 & 158 & 157 & 1,03 & 13,10 & 1,55 & 0,804 & 6 & 0,095 & 1,9 & 585 & \pm 11 & 653 & \pm 120 & 10 \\
\hline 7.1 & 336 & 408 & 1,25 & 27,40 & 1,81 & 0,704 & 6,6 & 0,0934 & 1,8 & 576 & \pm 10 & 397 & \pm 140 & -45 \\
\hline 8.1 & 86 & 126 & 1,52 & 7,31 & 2,58 & 0,792 & 11,0 & 0,0965 & 2,3 & 594 & \pm 13 & 585 & \pm 230 & -1 \\
\hline 9.1 & 190 & 175 & 0,95 & 15,80 & 0,61 & 0,775 & 4,3 & 0,0962 & 1,9 & 592 & \pm 11 & 545 & \pm 83 & -9 \\
\hline 10.1 & 259 & 297 & 1,19 & 23,00 & 0,70 & 0,867 & 3,7 & 0,1028 & 1,8 & 631 & \pm 11 & 646 & \pm 71 & 2 \\
\hline 11.1 & 135 & 106 & 0,82 & 11,30 & 1,99 & 0,768 & 8,1 & 0,0952 & 2,1 & 586 & \pm 12 & 548 & \pm 170 & -7 \\
\hline 12.1 & 215 & 226 & 1,08 & 18,70 & 0,69 & 0,815 & 3,8 & 0,1007 & 1,7 & 618 & \pm 10 & 556 & \pm 75 & -11 \\
\hline 13.1 & 214 & 237 & 1,14 & 17,50 & 1,18 & 0,794 & 5,7 & 0,0938 & 2 & 578 & \pm 11 & 652 & \pm 110 & 11 \\
\hline 14.1 & 279 & 251 & 0,93 & 23,30 & 1,16 & 0,795 & 4,1 & 0,0963 & 1,7 & 592,5 & $\pm 9,6$ & 601 & \pm 80 & 1 \\
\hline 15.1 & 320 & 297 & 0,96 & 27,10 & 0,49 & 0,801 & 2,4 & 0,098 & 1,7 & 602,5 & $\pm 9,5$ & 579 & \pm 39 & -4 \\
\hline
\end{tabular}

Erros são 1 sigma; $\mathrm{Pb}_{c}$ indica chumbo comum e $\mathrm{Pb}^{*}$ indica chumbo radiogênico. O erro na calibração do padrão foi de 0,57\% (não incluído nos erros calculados acima porém necessário quando comparar com dados de diferentes amostras). (1) Em todas as razões e idades, a correção para o chumbo comum foi realizada utilizando o valor do ${ }^{204} \mathrm{~Pb}$ medido. 


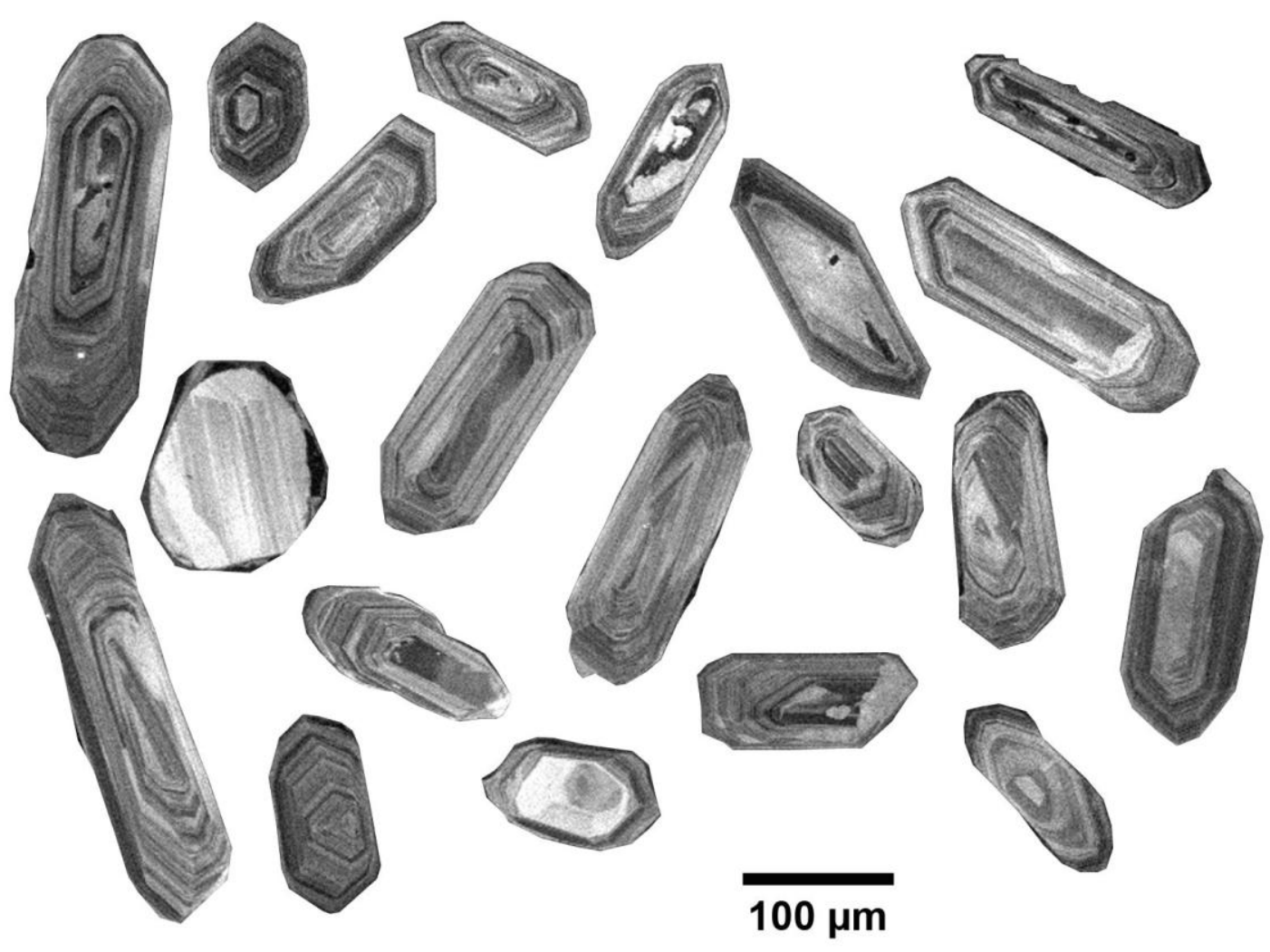

Figura 3-30: Imagem de catodoluminescência. Mount dos cristais de zircão com marcante zoneamento magmático
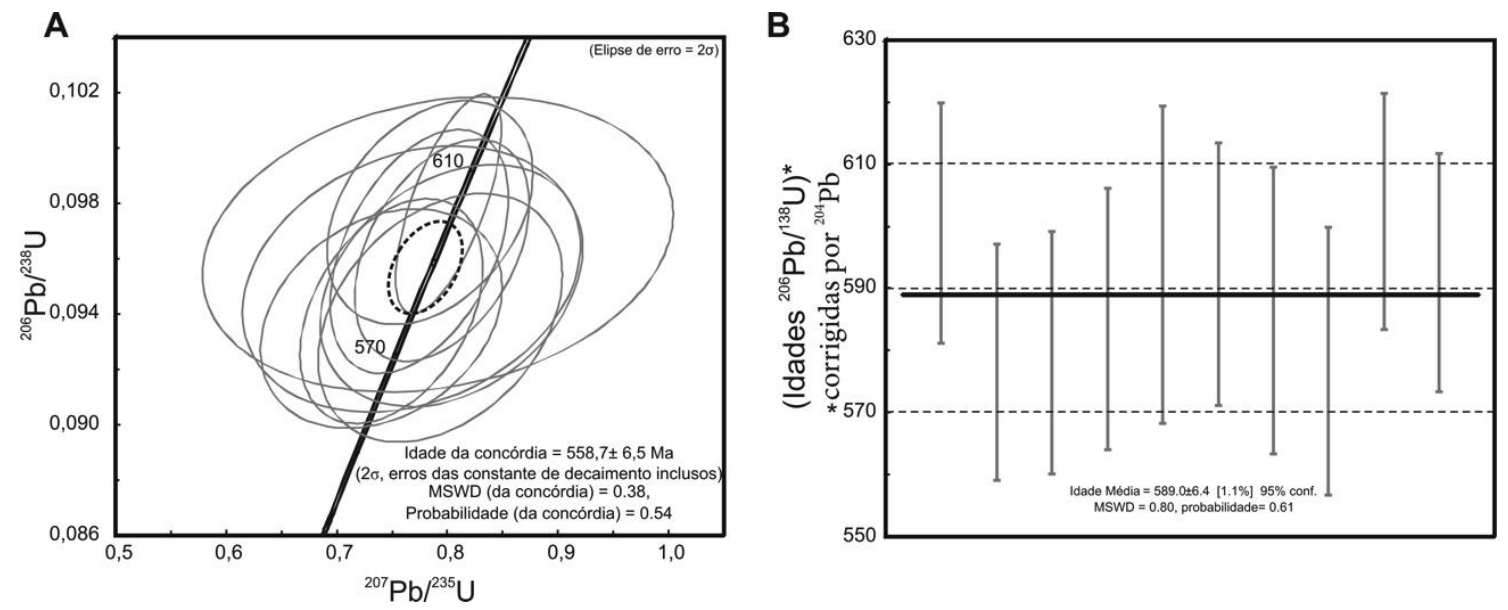

Figura 3-31: A) Idade concórdia do Granito Patrimônio Santo Antônio obtida em zircões de um monzogranito porfirítico (Amostra SW-304), e (B) respectiva idade aparente (ver o texto) 


\subsubsection{Granito São Domingos (Np3p $\gamma 2$ Isd)}

O termo Granito São Domingos foi originalmente proposto por Soares et al. (1987) para definir o corpo granítico aflorante próximo à localidade homônima. O autor também descreve a forte alteração hidrotermal que o afeta, com a ocorrência de fluorita e sulfetos disseminados.

O stock granítico São Domingos possui uma forma irregular com dimensões aproximadas de $4 \mathrm{~km}$ de largura e $6 \mathrm{~km}$ de comprimento. O corpo está localizado entre o bairro de São Domingos e o distrito de Ouro Verde, em Sengés - PR (fig. 3-32).

Em geral trata-se de um granito róseo, isótropo, leucocrático, bastante fraturado e com variação textural entre fanerítica grossa (figs. 3-33 e 3-34) e afanítica. A rocha possui composição mineralógica dada por quartzo, biotita, plagioclásio e feldspato alcalino, comumente ocorrendo fluorita como mineral acessório principal, especialmente de forma disseminada nas pequenas fraturas.

Na descrição microscópica a rocha possui uma textura hipidiomórfica e um padrão de alteração acentuado, frequentemente com a biotita cloritizada e o plagioclásio saussuritizado (fig. 3-35). Os cristais de opacos são idiomórficos (provavelmente magnetita) e quase sempre associados na borda ou inclusos nos cristais de biotita e clorita. Os minerais acessórios principais são titanita e apatita.

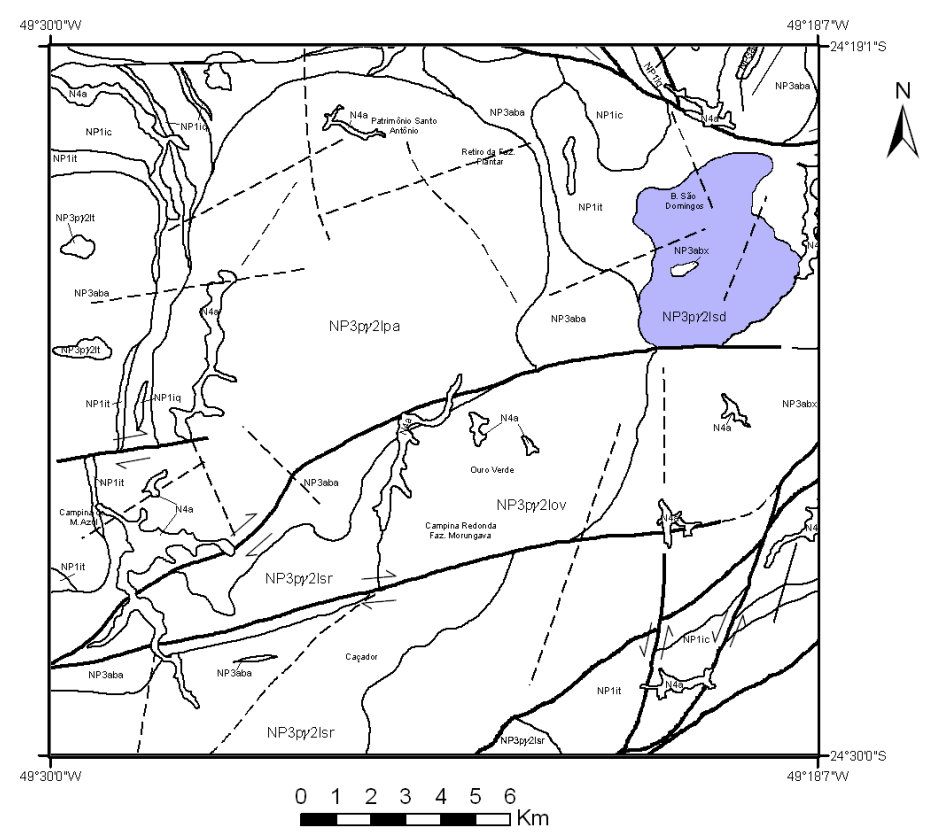

Figura 3-32: Granito São Domingos (NP3pr2Isd) 


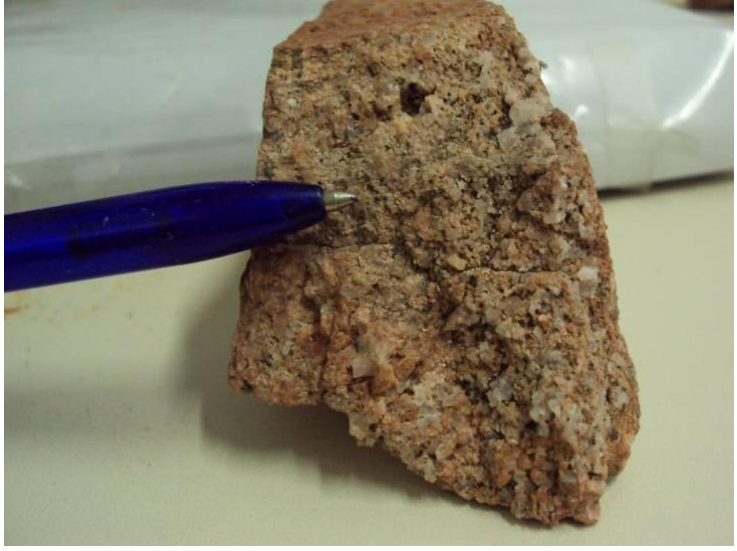

Figura 3-33: Foto do biotita granito fanerítico, hololeucocrático, cor vermelha a rosa clara, granulação fina a média, do Granito São Domingos (NP3r2lsd). (Afloramento localizado na estação de ASM 35, $4 \mathrm{~km}$ a sudeste do Bairro São Domingos, Sengés-(PR)

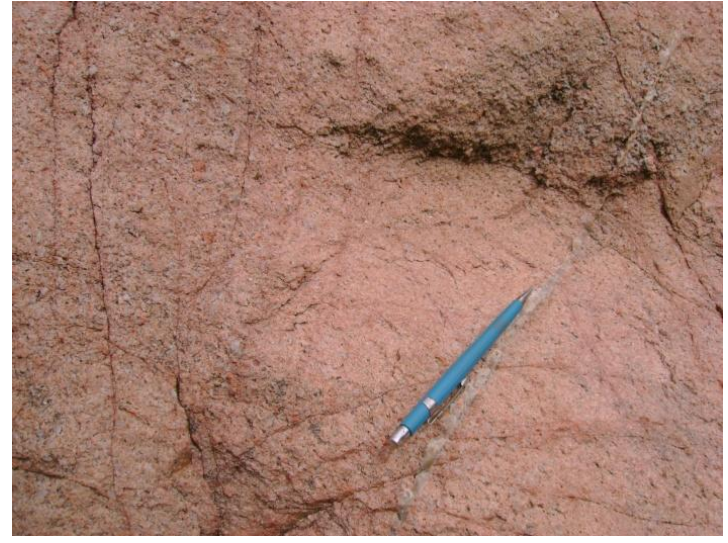

Figura 3-34: Foto do biotita granito fanerítico, hololeucocrático, cor vermelha a rosa clara, granulação fina a média, do Granito São Domingos (NP3r2lsd) com vênulas sub-centimétricas. (Afloramento localizado na estação de ASM 35, $4 \mathrm{~km}$ a sudeste do Bairro São Domingos, Sengés-(PR)

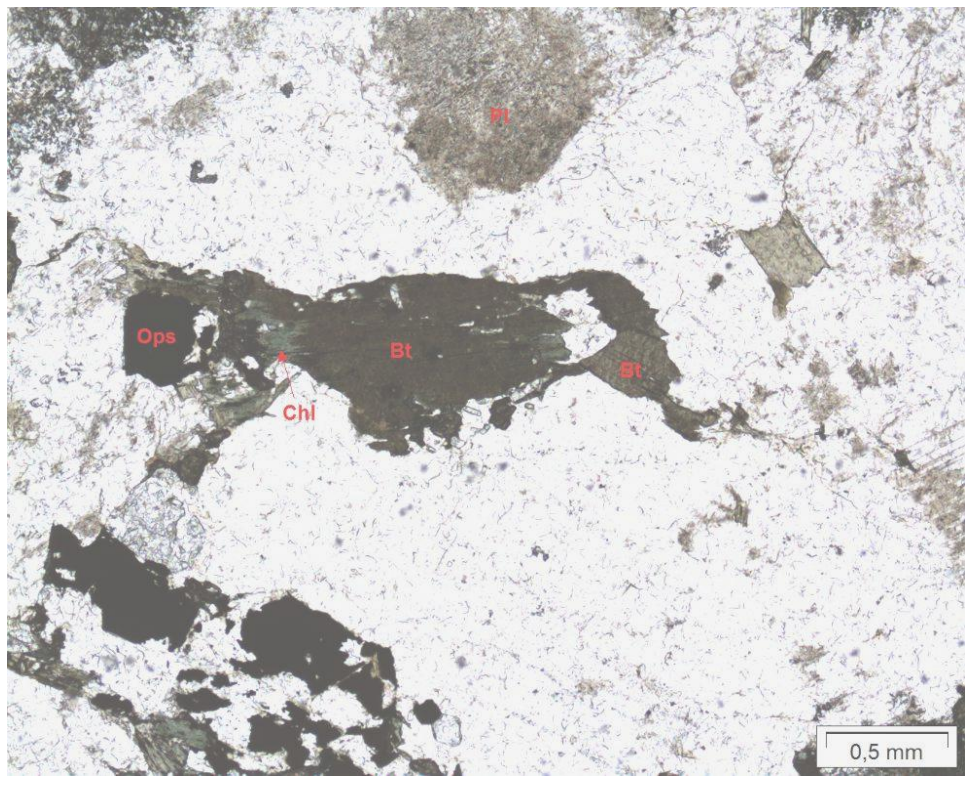

Figura 3-35: Fotomicrografia do biotita monzogranito com nicóis descruzados. Biotita cloritizada com associação de opacos e cristais de plagioclásio saussuritizados (Afloramento localizado na estação de ASM 35, 4 km a sudeste do Bairro São Domingos, Sengés-(PR) 


\subsubsection{Granitos Indiferenciados (NP3p $\gamma 2$ It)}

$\mathrm{Na}$ área de estudo ocorrem uma série de pequenas intrusões graníticas associadas à Suíte Intrusiva Cunhaporanga, principalmente na porção oeste. Estes plútons são denominados de "granitos indiferenciados" e são constituídos por biotita monzogranitos a sienogranitos com textura fanerítica fina a porfirítica. A principal ocorrência está localizada no cânion do rio Jaguaricatu, próximo da escarpa da Formação Furnas.

\subsection{Formação Furnas (Dlf)}

A Formação Furnas (fig.3-36) é encontrada ao norte da área de estudo em contato discordante com as rochas metassedimentares do Grupo Itaiacoca e com os granitos indiferenciados da Suíte Intrusiva Cunhaporanga. Esta relação de contato é bem demarcada por uma extensa zona de escarpas que se destacam na paisagem. Além dessas escarpas, é comum observar falhas rúpteis, camadas basculadas e brechas tectônicas associadas nesta transição.

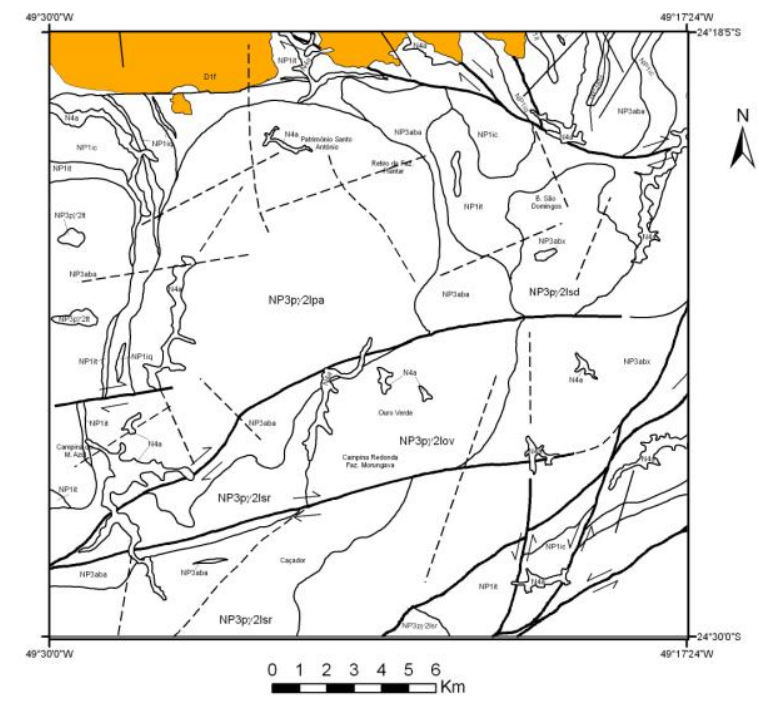

Figura 3-366: Formação Furnas (Dlf)

Em suma, trata-se de uma unidade essencialmente siliciclástica, constituída principalmente por um arenito de cor branca, mal selecionado, granulometria fina a grossa e com cristais de quartzo subangulosos a subarredondados com baixa a alta esfericidade. Sua composição mineralógica é dada por quartzo, feldspato, muscovita e turmalina e suas principais estruturas sedimentares são: estratificação plano-paralela, estratificação cruzada tabular e acanalada, marcas onduladas e estratificação gradacional granodecrescente. 


\subsection{Sedimentação Cenozoica $(\mathrm{N} 4 a)$}

São depósitos aluvionares nas margens, fundos de canal e planície de inundação que ocorrem como areias, cascalheiras e argilas resultantes do processo de erosão, transporte e deposição oriundos de diversas áreas-fonte. 


\section{Características geofísicas da área de estudo}

A aerogeofísica é o método de aquisição de dados geofísicos através de levantamentos aéreos. Para reconhecimentos geológicos é comum equipar a aeronave com sensores magnéticos e gamaespectrométricos multicanal, além de equipamentos para registros digitais das medidas geofísicas e controle de navegação.

\subsection{Levantamento aerogeofísico utilizado}

Os dados aerogeofísicos disponíveis para a região são originados de dois projetos executados na década de 70 e que são mostrados na figura 4.1: Serra do Mar Sul e São Paulo - Rio de Janeiro.

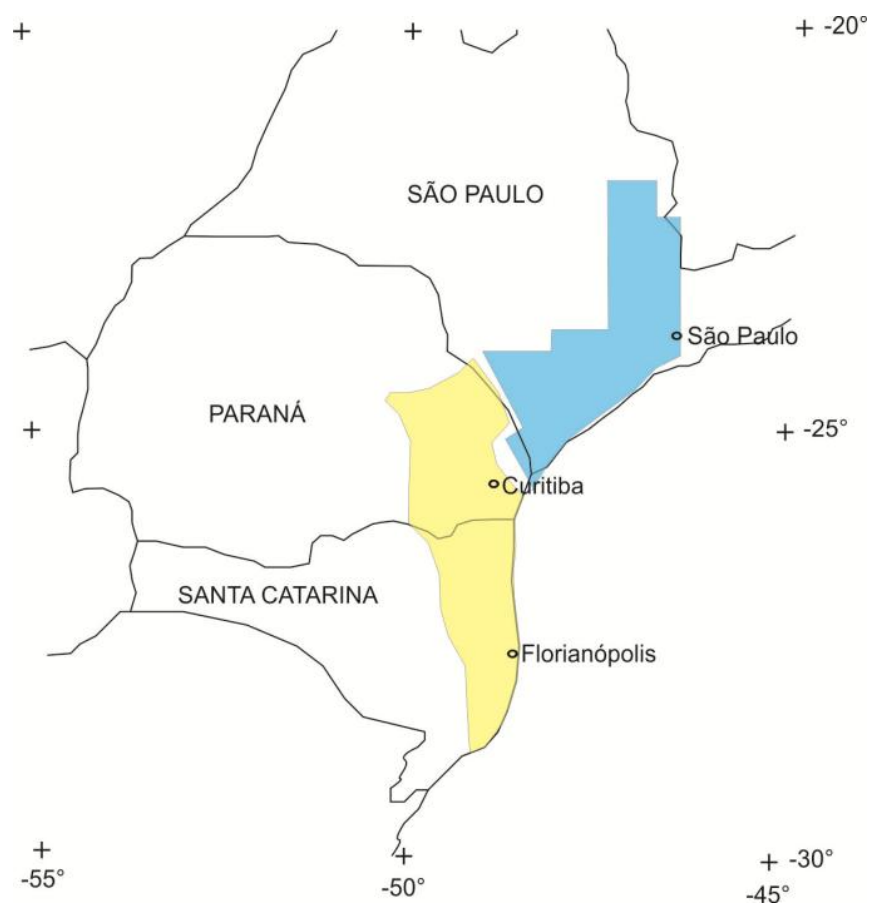

Figura 4-1: Principais levantamentos aerogeofísicos disponíveis na região. A região em azul é referente à área do projeto São Paulo - Rio de Janeiro (Área São Paulo) e a região em amarelo é referente à área do projeto Serra do Mar Sul

Na área de estudo há uma série de trabalhos (Silva e Mantovani, 1994; Guimarães et al. 2001; Ferreira et al., 2009, Ulbrich et al., 2009 etc) que abordam aspectos metodológicos e de emprego dos levantamentos aerogeofísicos utilizados e sua aplicação nas rochas graníticas 50 
associadas à Suíte Intrusiva Cunhaporanga, em especial para os sensores gamaespectométricos.

\subsection{Dados utilizados}

Os dados aerogeofísicos utilizados são os dos Projetos Aerogeofísicos Serra do Mar Sul (1025) do ano de 1975 e São Paulo-Rio de Janeiro (1039) do ano de 1978. No Projeto Serra do Mar Sul, as linhas de voo apresentam direção N30W com espaçamento de $1 \mathrm{~km}$ entre as mesmas e linhas de controle espaçadas de $20 \mathrm{~km}$ com direção N60E. Os registros foram obtidos, aproximadamente, a cada $1 \mathrm{~s}$, sendo a altura de voo de $150 \mathrm{~m}$.

O Projeto São Paulo-Rio de Janeiro foi levantado com linhas de voo de direção N-S, espaçadas a cada $1 \mathrm{~km}$ e linhas de controle espaçadas de $10 \mathrm{~km}$ com direção E-W. Os registros foram obtidos, aproximadamente, a cada $60 \mathrm{~m}$ voados, sendo a altura do voo de 150 m.

O processamento de dados tem por objetivo a geração de diferentes temas sob a forma de grids, que são elaborados de acordo com a necessidade da utilização das informações aerogeofísicas. As dimensões destes grids obedecem às limitações que são estabelecidas através dos parâmetros do levantamento aéreo.

Na geração dos grids utilizou-se o software Oasis Montaj (Versão 7.2) da Geosoft, adotando-se para os diversos temas as dimensões de 250x250 metros.

Os mapas gerados foram os seguintes:

a) Magnetométricos - Campo magnético residual (nT - nanoTesla) e Primeira derivada $\operatorname{vertical}\left(n T /^{\circ}\right)$.

b) Gamaespectométricos - Contagem de Tório (ppm).

Nesta dissertação serão apresentadas apenas as imagens dos grids de maior importância para os trabalhos de interpretação, sendo eles: magnetométricos (Campo magnético total, sinal analítico e primeira derivada) e os gamaespectométricos (Tório). 


\subsection{Mapas magnetométricos}

Os mapas magnetométricos foram os que mais contribuíram com informações relacionadas à geologia estrutural da área, tornando-os útil para a definição do arcabouço tectono-estrutural da região.

A figura 4-2 mostra o mapa de campo magnético total reduzido do IGRF (International Geomagnetic Reference Field) da área estudada. Nota-se uma característica comum a este tipo de mapa denominada bipolaridade, que é a existência de valores positivos (em vermelho) associados a valores negativos (em azul). O mapa apresentado é caracterizado por duas grandes bipolaridades: uma a oeste, destacando o Granito Patrimônio Santo Antônio (NP3y2/pa) com valores de amplitude entre $154 \mathrm{nT}$ e $-98 \mathrm{nT}$; e outra a sudeste, ressaltando a anomalia magnética das rochas associadas a Suíte Intrusiva Três Córregos, sendo possível inferir seu contato tectônico com as rochas metassedimentares do Grupo Itaiacoca pode ser inferido através da Zona de Cisalhamento de Itapirapuã (Z.C.I).

Outro mapa magnetométrico utilizado para as interpretações é o da primeira derivada vertical do campo magnético total (fig.4-3), que é conhecido por realçar as estruturas magnéticas (falhas/fraturas). Observa-se no mapa que o alinhamento magnético principal possui direção NE-SW, ressaltado principalmente pela Z.C.I. e pelas falhas que cortam os granitos associados à Suíte Intrusiva Cunhaporanga. 


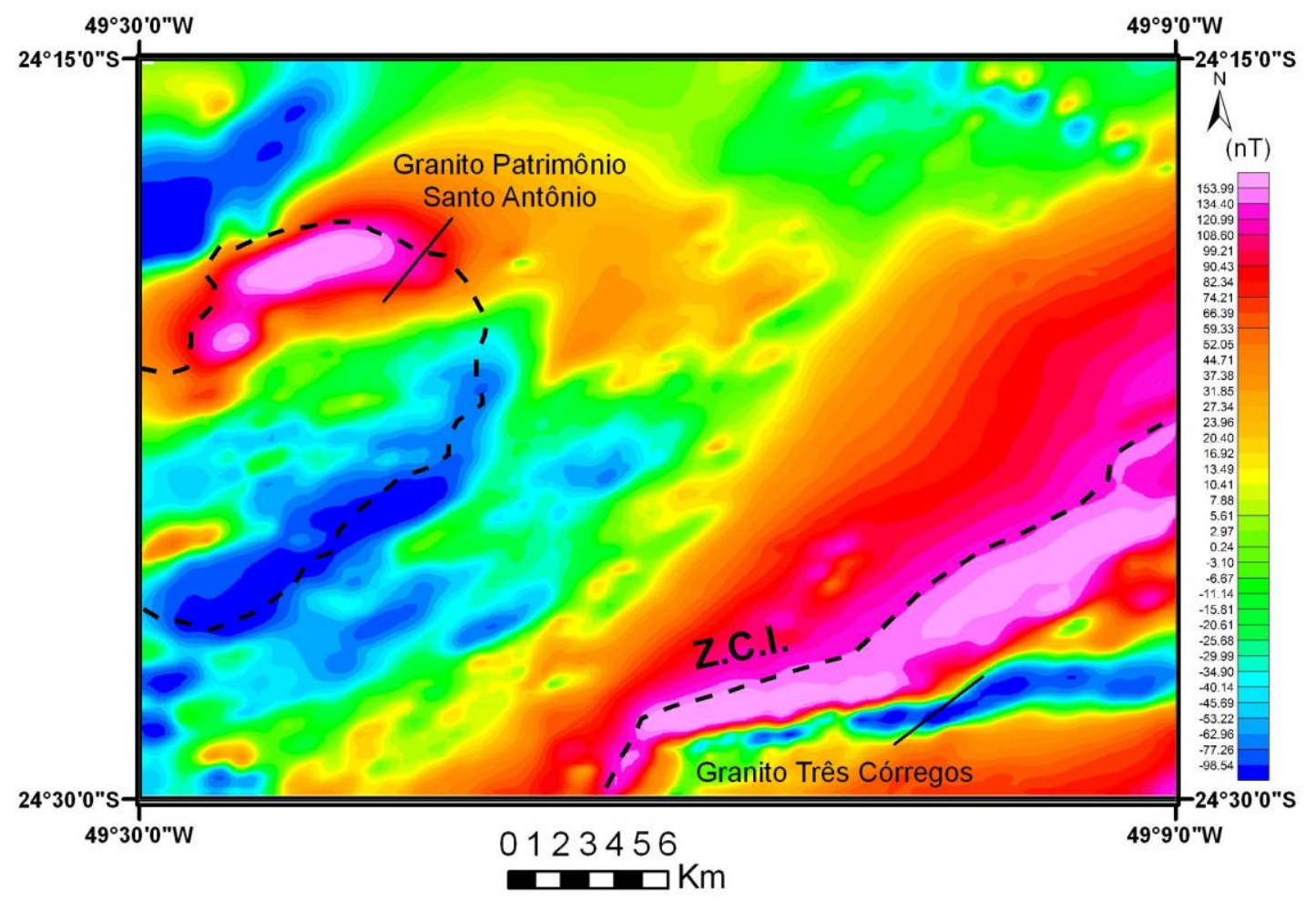

Figura 4-2: Mapa do campo magnético total reduzido do IGRF (International Geomagnetic Reference Field)

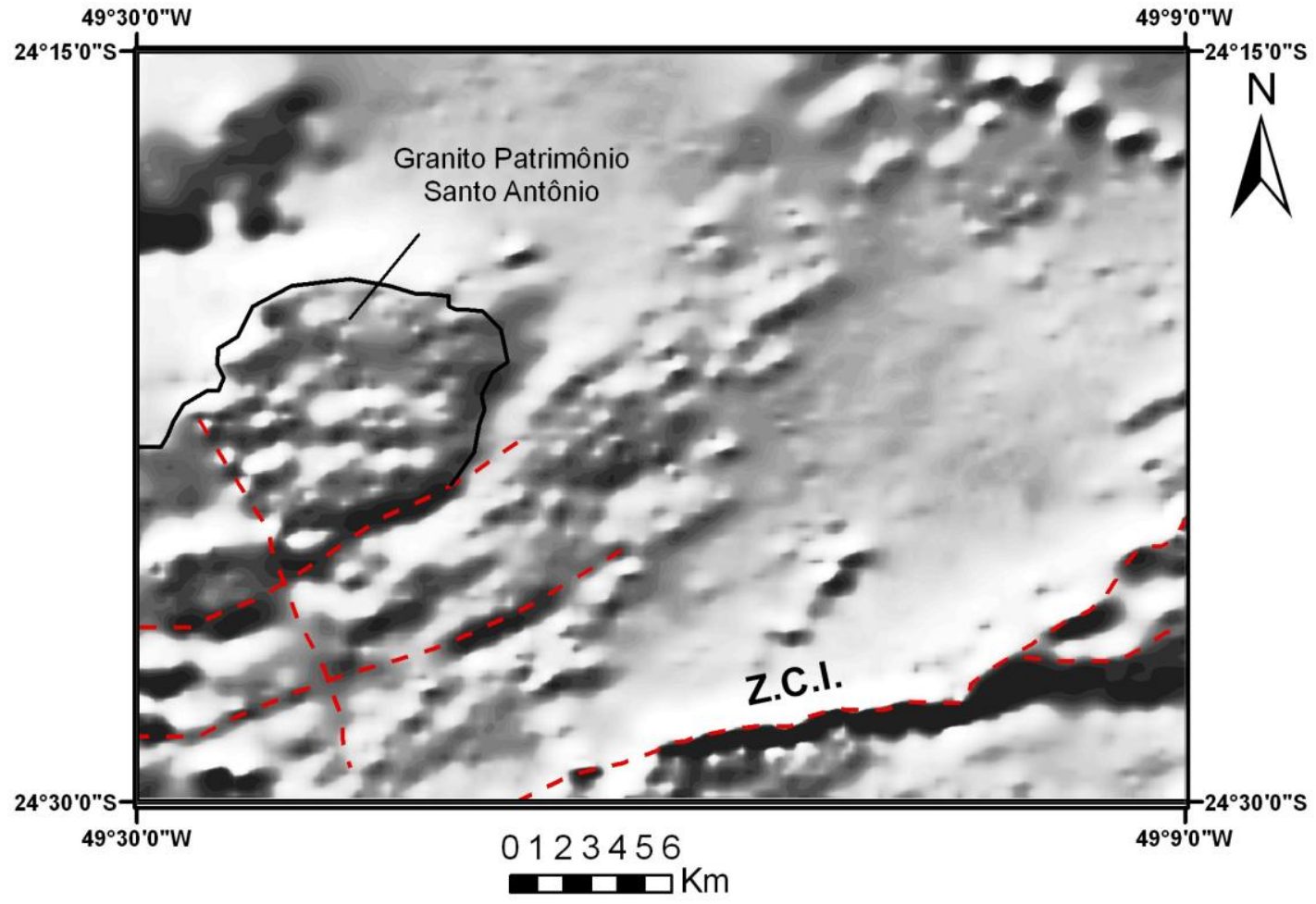

Figura 4-3: Mapa da primeira derivada vertical do campo magnético total 


\subsection{Mapas gamaespectrométricos}

A gamaespectrometria ou radiometria costuma ser vista como um guia para localizar rochas com radioatividades acima do background, como os granitoides e as rochas alcalinas.

Neste trabalho optou-se por utilizar apenas o mapa gamaespectrométrico do canal do Tório (Th), pois por ser um elemento com menor mobilidade apesenta grande contraste para discriminar diferentes associações litológicas. Ele ocorre principalmente em granitos e pegmatitos na composição química do mineral de monazita. Na área de estudo é possível destacar tanto o Granito Patrimônio Santo Antônio (NP3r2lpa) como as rochas associadas à Suíte Intrusiva Três Córregos pela alta concentração de Tório, com valores próximo a 20 ppm.

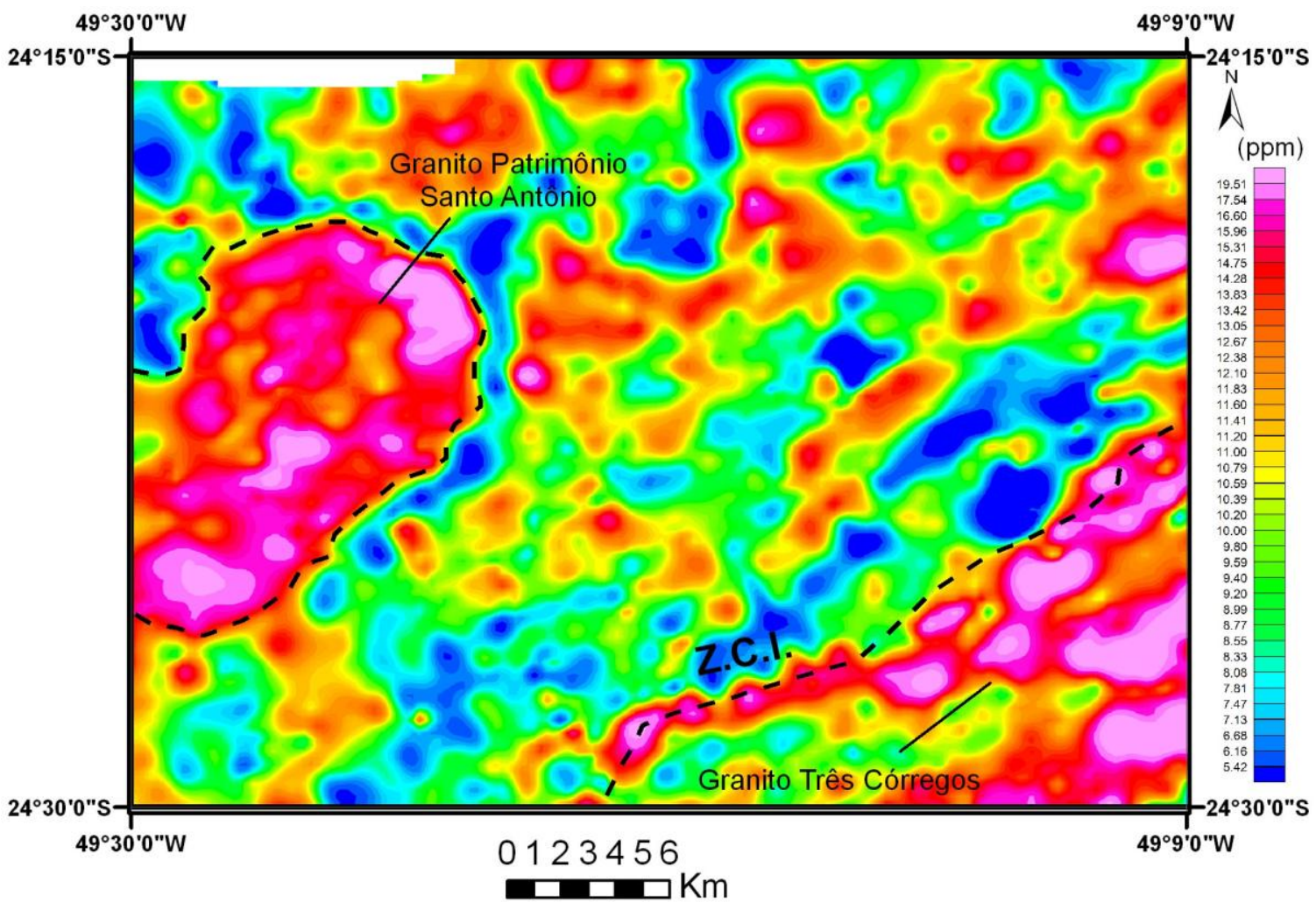

Figura 4-4: Mapa gamespectrométrico no canal do tório 


\section{Geologia Estrutural}

Como citado anteriormente, no Domínio Apiaí a Suíte Intrusiva Cunhaporanga ocorre intrudida no Grupo Itaiacoca. O mapeamento geológico das rochas encaixantes foi de extrema importância, pois além de estabelecer as relações de contato com os plútons graníticos também forneceu dados estruturais que auxiliaram na formulação do modelo de alojamento e deformação destes granitos. Com estes dados foi possível separar as unidades do Grupo Itaiacoca em diferentes domínios estruturais que serão detalhados a seguir.

\subsection{Grupo Itaiacoca}

Apesar das formações do Grupo Itaiacoca apresentar em idades distintas (conforme exposto no capitulo 3), o padrão estrutural observado é bastante similar. Em geral destaca-se o metamorfismo regional de baixo grau (fácies xisto verde), a preservação de estruturas primárias, o desenvolvimento de amplas dobras em grandes escalas e o forte controle estrutural tanto pelas intrusões graníticas como pelas zonas de cisalhamento.

As unidades do Grupo Itaiacoca possuem um padrão estrutural relativamente simples, conforme já descrito em trabalhos anteriores (Hasui et al, 1980; Theodorovicz et al., 1986; Souza, 1990; Siga Jr et al., 2003). A estrutura principal observada é o acamamento sedimentar reliquiar $\left(\mathrm{S}_{0}\right)$ paralelo a uma xistosidade ou clivagem ardosiana penetrativa $\left(\mathrm{S}_{1}\right)$, associadas a uma primeira fase de dobramento $\left(\mathrm{D}_{1}\right)$ com desenvolvimento de dobras isoclinais e fechadas. Esta superfície principal $\left(\mathrm{S}_{1} / / \mathrm{S}_{0}\right)$ é afetada posteriormente por outra fase de dobramento $\left(\mathrm{D}_{2}\right)$, ora desenvolvendo uma clivagem de crenulação (fig. 5-1) em rochas de baixa competência (metapelitos e filitos) e ora desenvolvendo uma clivagem disjuntiva espaçada (fig. 5-2) nas rochas com maior competência (quartzitos e metarenitos). 


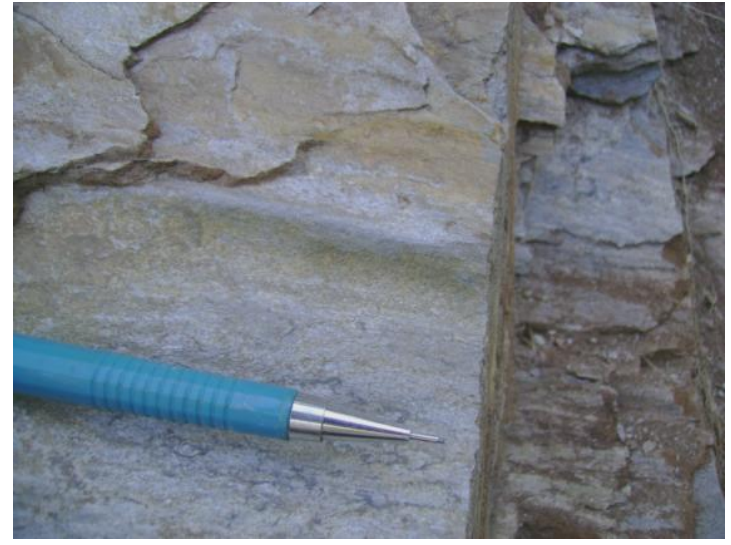

Figura 5-1: Foto exibindo a lineação de crenulação (Lb), associada a uma clivagem de crenulação em filito bandado da Formação Água Nova (NPlit) (Afloramento localizado no ponto SW-316, a noroeste do Bairro São Domingos)

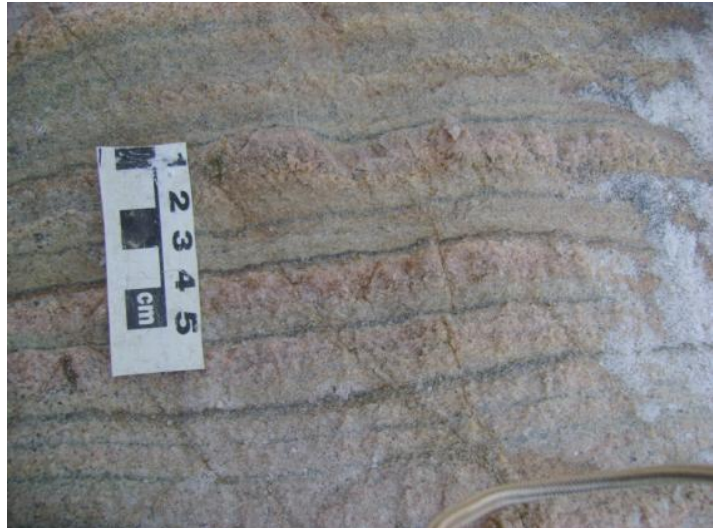

Figura 5-2: Foto da clivagem disjuntiva espaçada (clivagem de fratura) em metarenito/metaritmito feldspático bandado (metawackes) da Formação Abapã (NP3abx) (Afloramento localizado no ponto $S W-114,2 \mathrm{~km}$ a noroeste do distrito de Ouro Verde, Sengés - PR)

$\mathrm{Na}$ área de estudo, o Grupo Itaiacoca pode ser separado em dois grandes domínios estruturais. O primeiro, situado na porção leste, possui direção NE-SW e quase sempre está associado às zonas de cisalhamento (Domínio da Zona de Cisalhamento Itapirapuã). Já o segundo domínio está localizado na porção oeste e apresenta um forte controle estrutural associado aos corpos graníticos da Suíte Granítica Cunhaporanga (Domínio Estrutural Oeste).

\subsubsection{Domínio da Zona de Cisalhamento Itapirapuã}

A Zona de Cisalhamento Itapirapuã (Z.C.I.) é a feição estrutural mais expressiva da área de estudo, não apenas pela resposta no campo magnético total (fig.5-3) ou pela sua grande extensão territorial, mas também pela grande influência exercida nos metassedimentos do Grupo Itaiacoca próximo ao contato com a Suíte Intrusiva Três Córregos (SITC). Tanto que as estruturas das rochas desse grupo na porção leste tendem a paralelizar com Z.C.I., caracterizando o domínio estrutural dessa região. 


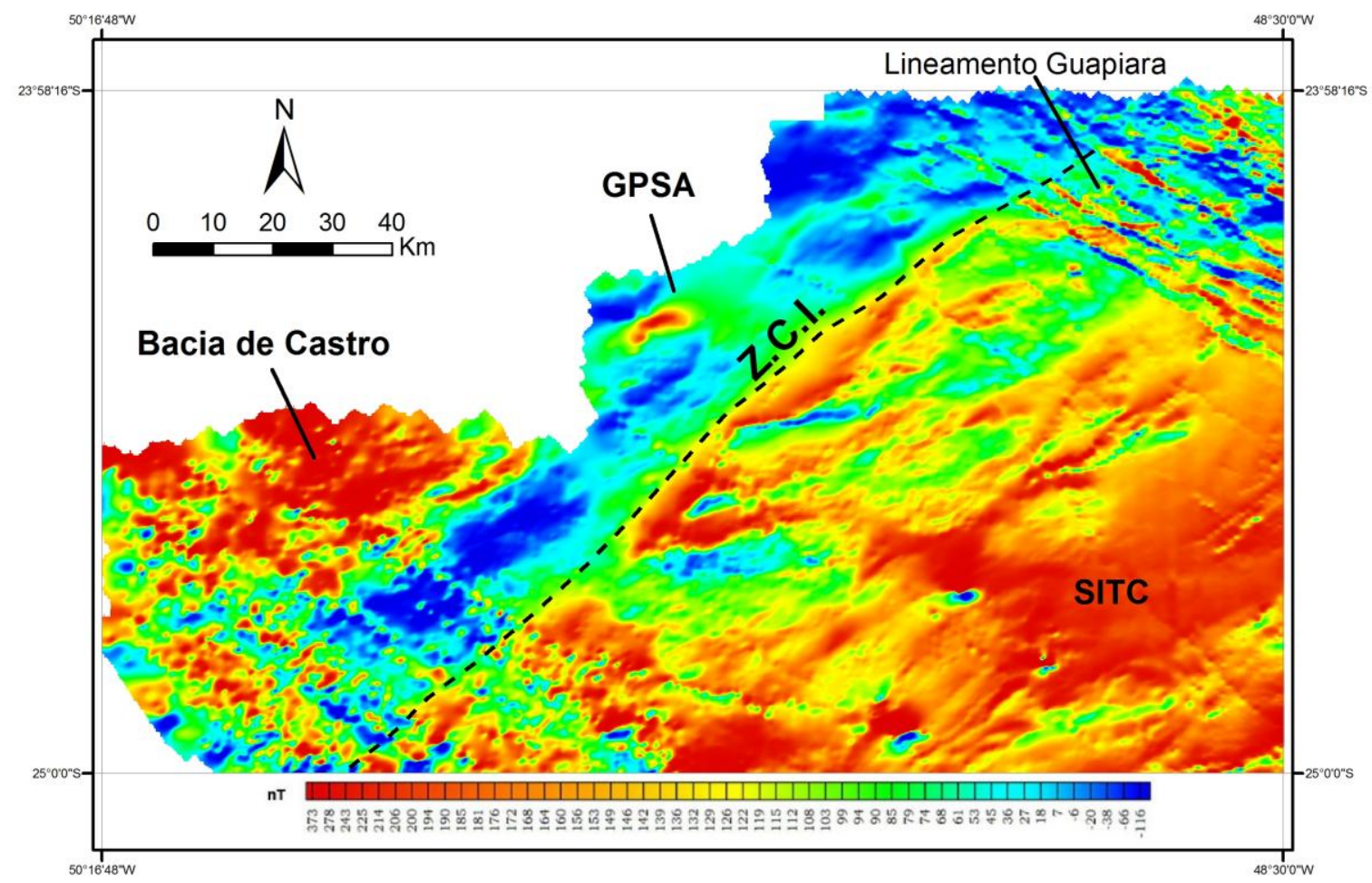

Figura 5-3: Campo Magnético total reduzido do IGRF. GPSA e SITC indicam Granito Patrimônio Santo Antônio e Suíte Intrusiva Três Córregos respectivamente

O Domínio da Zona de Cisalhamento Itapirapuã (fig.5-4) é caracterizado por uma faixa alongada de direção NE-SW localizada entre os sedimentos da Bacia do Paraná e as rochas graníticas SITC. O seu limite é determinado por duas zonas de cisalhamento, conhecidas como a própria Itapirapuã e a Estiva. A primeira separa tectonicamente os metassedimentos do Grupo Itaicoca dos granitos da SITC, enquanto a Zona de Cisalhamento da Estiva (Z.C.E.) limita a influência deste domínio com o Domínio Estrutural Oeste.

Neste domínio é frequente uma série de antiformes e sinformes com traço axial de direção NE-SW, assim como zonas de cisalhamento rúpteis/dúcteis com mesma direção. Estas zonas de cisalhamento possuem um importante papel nas mineralizações de talco no Grupo Itaiacoca, especialmente a Zona de Cisalhamento Itapirapuã. Szabó et al. (2006) destacam que as grandes concentrações de talco foram desenvolvidas ao longo de ramificações desta zona acompanhados de intensa atividade hidrotermal. 


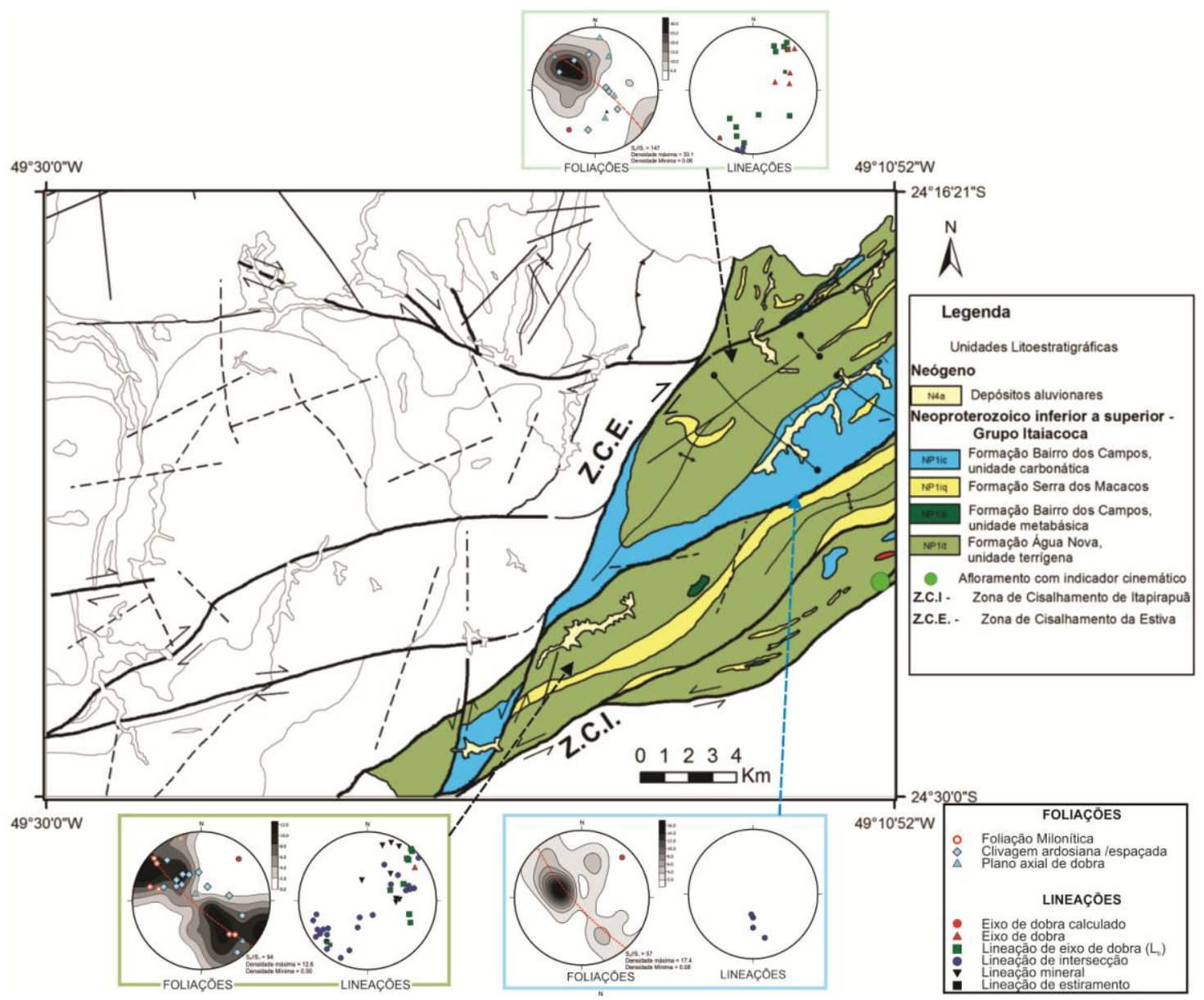

Figura 5-4: Domínio da Zona de Cisalhamento Itapirapuã

Os estereogramas (fig.5-4) tanto da Formação Bairro dos Campos (NPlic) como da Formação Água Nova (NP3it) apresentam características estruturais semelhantes. Os pólos da foliação principal $\left(\mathrm{S}_{0} / / \mathrm{S}_{1}\right)$ ocorrem distribuídos ao longo de guirlandas de círculo máximo (plano AC) com orientação aproximada NW - SE, e mergulhos de alto ângulo para NE ou $\mathrm{SW}$, indicando um dobramento cilíndrico com eixos distribuídos na direção NE - SW. Este dobramento provavelmente está relacionado à série de antiformes e sinformes com traços axiais de direção NE - SW mencionadas anteriormente. Diversos autores (Theodorovicz et al., 1986; Souza, 1990 etc) associam este conjunto de dobras a uma fase $\mathrm{D}_{2}$ de dobramentos associados com estruturas de cavalgamento e geração de uma foliação $S_{2}$ (clivagem de crenulação).

No geral este domínio é marcado por um conjunto de falhas que são caracterizadas por faixas de espessura irregular, da ordem de metros a dezenas de metros, onde ocorrem termos miloníticos e cataclasíticos principalmente no contato com a SITC. Os indicadores cinemáticos em escala de afloramento são escassos, no entanto ao microscópio óptico, nas 
rochas com textura milonítica, ocorrem pares de foliações SC e porfiroclastos assimétricos, que indicam cinemática sinistral (fig.5-5).

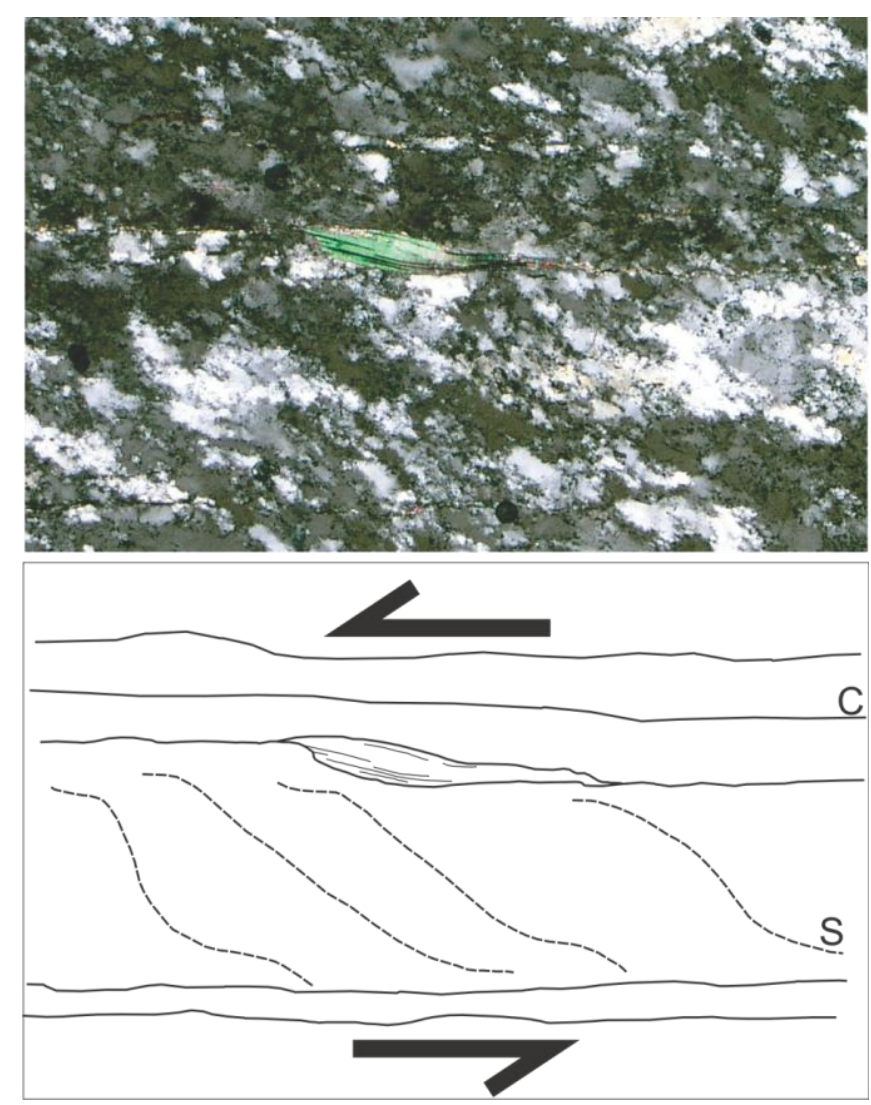

Figura 5-5: Fotomicrografia de muscovita quartzito com polarizadores cruzados. Detalhe da muscovita com estrutura sigmoidal como mica fish, indicando movimento sinistral. Lado maior da foto = 3,5 mm

\subsubsection{Domínio Estrutural Oeste}

O Domínio Estrutural Oeste (fig.5-6) do Grupo Itaiacoca é caracterizado pelas rochas metassedimentares ao redor dos plútons graníticos da Suíte Cunhaporanga. Neste domínio é observada uma série de antiformes e sinformes com traços axiais de direção N-S a NNESSW, além de zonas de cisalhamento rúpteis/dúcteis com direção ENE-WSW e NNE-SSW. É possível destacar o forte controle estrutural pelas intrusões graníticas afetando principalmente as foliações nas rochas metassedimentares do Grupo Itaiacoca. 

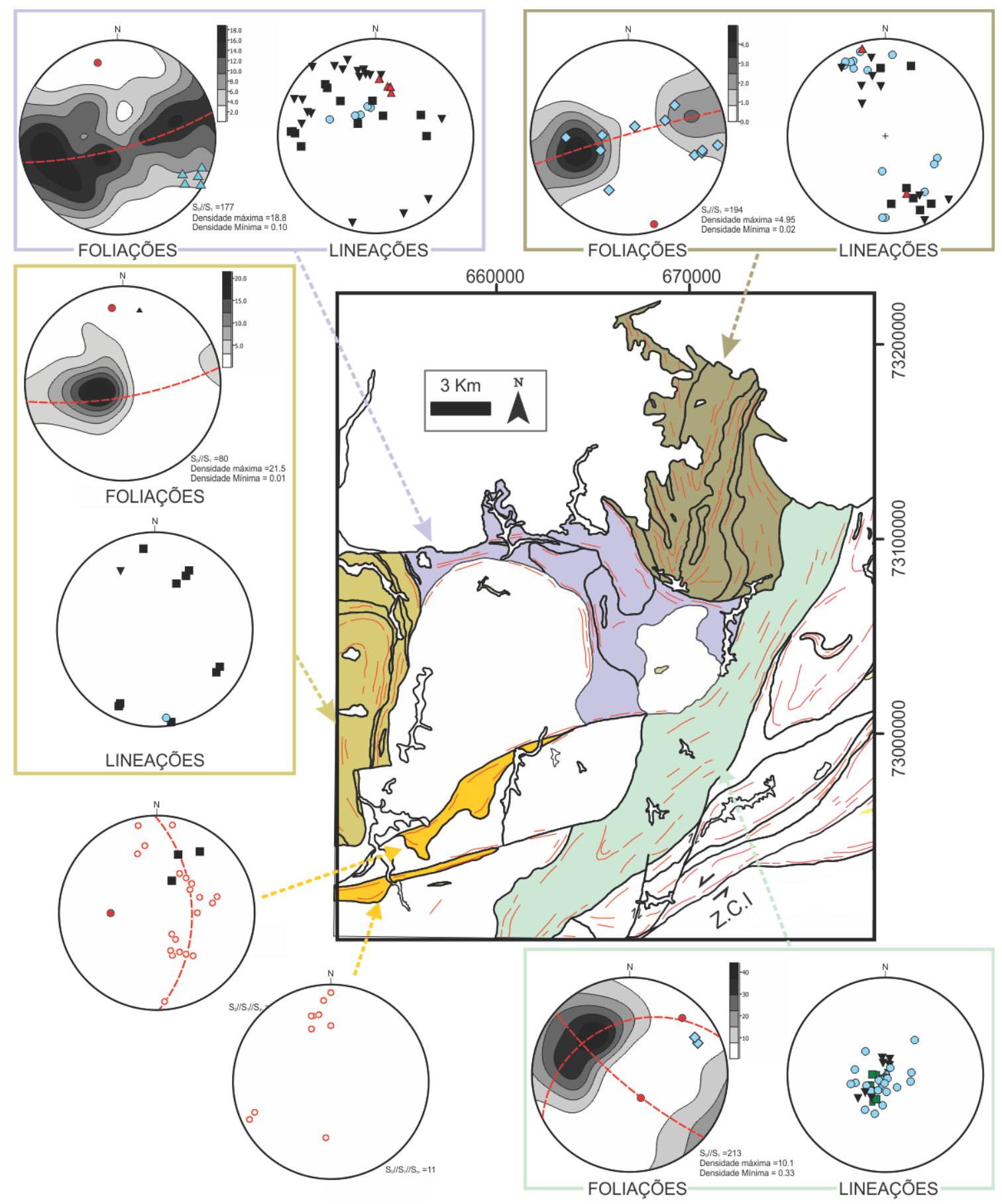

\section{LEGENDA}

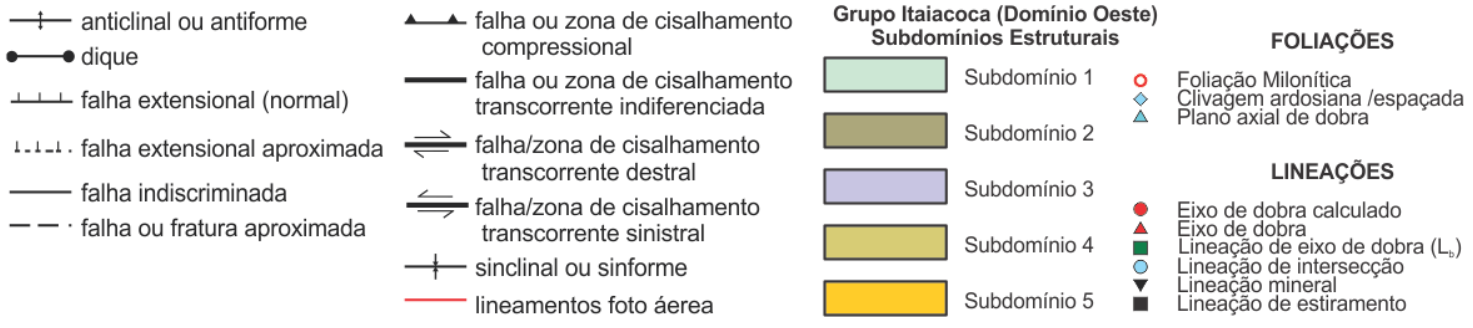

Figura 5-6: Domínio Estrutural Oeste 
Para uma melhor compreensão da relação entre as encaixantes e os plútons graníticos da Suíte Intrusiva Cunhaporanga optou-se por dividir o Domínio Estrutural Oeste em 5 subdomínios, considerando seus aspectos litoestratigráficos e estruturais. Os subdomínios delimitados apresentam forte constraste nos estereogramas em relação à distribuição dos pólos da foliação principal $\left(\mathrm{S}_{0} / / \mathrm{S}_{1}\right)$ e das lineações.

O subdomínio 1 apresenta características similares ao Dominio da Zona de Cisalhamento Itapirapuã em relação à distribuição dos pólos da foliação principal $\left(\mathrm{S}_{1} / / \mathrm{S}_{0}\right)$, entretanto as lineações apresentam uma distribuição mais uniforme com direção predominantemente NE-SW de alto a médio caimento. No estereograma das foliações ocorre a dispersão dos pólos ao longo de duas guirlandas de círculo máximo (plano AC), com os respectivos valores: $\mathrm{N} 49^{\circ} \mathrm{W} / 77^{\circ} \mathrm{SW}$ (guirlanda inferida, com eixo $\mathrm{N} 40^{\circ} \mathrm{E} / 12^{\circ}$ ) e $\mathrm{N} 64^{\circ} \mathrm{E} / 30^{\circ} \mathrm{NW}$ (guirlanda calculada, com eixo: $\mathrm{S} 64^{\circ} \mathrm{E} / 59^{\circ}$ ). A primeira guirlanda é correlata às dobras $\mathrm{D}_{2}$ do domínio anterior, enquanto a guirlanda calculada representa uma possível fase posterior de dobramentos $\left(\mathrm{D}_{3}\right)$.

Os subdomínios 2, 3 e 4 apresentam um comportamento semelhante entre si. No estereograma das foliações a concentração dos pólos ocorre na direção ENE-WSW e a distribuição do círculo máximo ao longo das guirlandas com orientação aproximada E-W, com mergulhos de alto ângulo tanto para sul como norte.

O subdomínio 3 apresenta a maior dispersão dos pólos de foliação principal e das lineações. Este fato pode ser explicado pela própria localização deste subdomínio e consequente interação com os plútons graníticos Patrimônio Santo Antônio e São Domingos.

O subdomínio 5 é constituído por lentes de rochas metassedimentares da Formação Abapã (com predomínio de quartzito feldspático) localizadas em zonas de cisalhamento de direção ENE-WSW a E-W. Em um dos estereogramas das foliações deste domínio ocorre a dispersão dos pólos ao longo de uma guirlanda de círculo máximo (plano AC) com orientação $\mathrm{N} 02^{\circ} \mathrm{W} / 50^{\circ} \mathrm{NE}$ associado a um dobramento cilíndrico com eixo $\mathrm{S} 88^{\circ} \mathrm{W} / 38^{\circ}$.

A colocação dos plútons graníticos desta suíte, conforme já exposto, afeta a distribuição das foliações nas rochas metassedimentares, sugerindo a colocação forçada dos corpos graníticos a partir de mecanismos como o ballooning (Best \& Christiansen, 2001), no qual as paredes da encaixante são forçadas e empurradas para os lados pelo magma. Uma possível interpretação para a dispersão dos padrões estruturais observados em estereogramas e no mapa é de que a colocação dos magmas gerou um padrão de interferência por redobramento e acomodação das camadas pré-existentes. 
Quanto às zonas de cisalhamentos observadas neste domínio predominam termos cataclásticos e brechas tectônicas. As zonas de cisalhamentos de orientação ENE-WSW observadas neste domínio são bem expressivas, pórem com escassos e dúbeis indicadores cinemáticos. Em campo constituem importantes zonas de alteração hidrotermal caracterizadas por forte epidotização das rochas graníticas a elas associadas, e em alguns casos há a presença de mineralizações de sulfetos e fluorita. Aparentam ser uma fase mais tardia de deformação do que a observada nas zonas de cisalhamento NE-SW, associadas à Zona de Cisalhamento Itapirapuã. 


\section{Mineralogia Magnética}

As propriedades magnéticas dos plútons da Suíte Intrusiva Cunhaporanga (SIC) foram estudadas a partir de análises de susceptibilidade magnética, curvas termomagnéticas, curvas de aquisição de magnetização remanente isotermal (IRM) e complementadas com observações em microscópio eletrônico de varredura (MEV), obtidas em seções delgadas e fragmentos de rocha.

As amostras analisadas pela IRM e pelas curvas termomagnéticas são oriundas da mesma estação, porém são espécimes diferentes. Foram escolhidas seis amostras com susceptibilidade representativa, ou seja, mais próximo da média de cada granito: duas amostras do patrimônio Santo Antônio, uma do Ouro Verde, uma do Santa Rita e duas do São Domingos.

\subsection{Susceptibilidade Magnética}

Quando um material (e.g. uma rocha) é submetido a um campo indutor (H), o mesmo pode adquirir uma magnetização induzida (M). Em geral a susceptibilidade magnética (k) é diretamente proporcional à magnetização, conforme a equação (1):

$$
\mathrm{M}=\mathrm{kH}(1)
$$

No Sistema Internacional, os parâmetros $\mathrm{M}$ e $\mathrm{H}$ são medidos em $\mathrm{A} / \mathrm{m}$ e k é considerado adimensional.

A susceptibilidade magnética é o principal parâmetro magnético usado na interpretação geofísica e sua variação depende diretamente do tamanho do grão, da mineralogia magnética e da temperatura. Em temperatura ambiente e sob campo indutor de baixa intensidade $(<1 \mathrm{mT})$, a susceptibilidade volumétrica nos materiais rochosos varia entre $10^{-5}$ e $10^{-2}$ SI. A constituição mineralógica é um fator preponderante para a susceptibilidade: minerais como quartzo e feldspato apresentam susceptibilidade negativa, enquanto alguns óxidos de Fe, caso da magnetita, podem apresentar uma susceptibilidade de até 6 SI. Caso a rocha seja isótropa, $M$ tem a mesma intensidade independente da orientação do campo $\mathrm{H}$. Entretanto a maioria das rochas, assim como seus minerais constitutivos, geralmente são anisotrópicos e portanto $\mathrm{M}$ pode variar em intensidade com a orientação de H. Para uma 
determinada direção de indução, as componentes da magnetização induzida podem ser expressas pela seguinte equação (2):

$$
\mathrm{Mi}=\mathrm{Kij} \mathrm{Hj}
$$

Em que i,j = 1,2,3. Mi é a magnetização na direção i, Hj é o campo indutor na direção j.e Kij é uma matriz cartesiana simétrica de segunda ordem, também denominada por tensor de susceptibilidade (Nye 1957). Nesta matriz Kij é possível encontrar um sistema de coordenadas (autovetores) no qual os componentes de fora da diagonal se cancelam, sendo representada da seguinte maneira:

$$
\mathrm{Kij}=\left[\begin{array}{lll}
K_{1} & & \\
& K_{2} & \\
& & K_{3}
\end{array}\right] \text { (3) }
$$

A diagonal desta matriz resulta nos autovalores: máximo $\left(\mathrm{k}_{1}\right)$, intermediário $\left(\mathrm{k}_{2}\right)$ e mínimo $\left(\mathrm{k}_{3}\right)$ do tensor, cuja representação espacial gráfica mais intuitiva é um elipsóide triaxial. Desta forma cada eixo do elipsóide corresponderia a uma das susceptibilidades principais. $\mathrm{O}$ grau de anisotropia $(\mathrm{P})$ do elipsóide é dado pela relação $\mathrm{k}_{1} / \mathrm{k}_{3}$, enquanto o parâmetro da forma $(\mathrm{T})$ varia de oblato $\left(\mathrm{k}_{1}=\mathrm{k}_{2}>\mathrm{k}_{3}\right)$, prolato $\left(\mathrm{k}_{1}>\mathrm{k}_{2}=\mathrm{k}_{3}\right)$ e triaxial ou neutro $\left(\mathrm{k}_{1}>\mathrm{k}_{2}>\mathrm{k}_{3}\right)$.

\subsubsection{Susceptibilidade e anisotropia dos plútons da SIC}

A susceptibilidade magnética apresenta teores muito elevados nos granitos Patrimônio Santo Antônio e Santa Rita, quase sempre com valores acima de $10^{-2} \mathrm{SI}$ (>10mSI). No plúton Patrimônio Santo Antônio, a susceptibilidade (k) varia entre 3,6 mSI e 59,0 mSI, com média de 23,2 mSI e desvio padrão (dp.) de 9,1; valores de k acima de $10 \mathrm{mSI}$ são encontrados em $71 \%$ das espécimes (fig. 6.1). No Granito Santa Rita a susceptibilidade média é de 11,2 mSI e com um desvio padrão de 7,2, porém a variação é mais ampla com valores entre 0,06 mSI e 30,1 mSI. Os outros dois plútons, São Domingos e Ouro Verde, apresentam uma susceptibilidade média de 7,45 mSI e com desvio padrão de 4,5 e 5,4 respectivamente. A variação de $\mathrm{k}$ possui menor intensidade que os granitos anteriores, contudo a susceptibilidade nestes plútons também é considerada elevada, com valores situados entre $0,1 \mathrm{mSI}$ e $18 \mathrm{mSI}$. No geral, entre $80 \%$ e $85 \%$ dos espécimes analisados possuem $\mathrm{k}>1 \mathrm{mSI}$, indicando que as rochas da SIC pertencem aos granitos da série à magnetita de Ishihara (1977). 


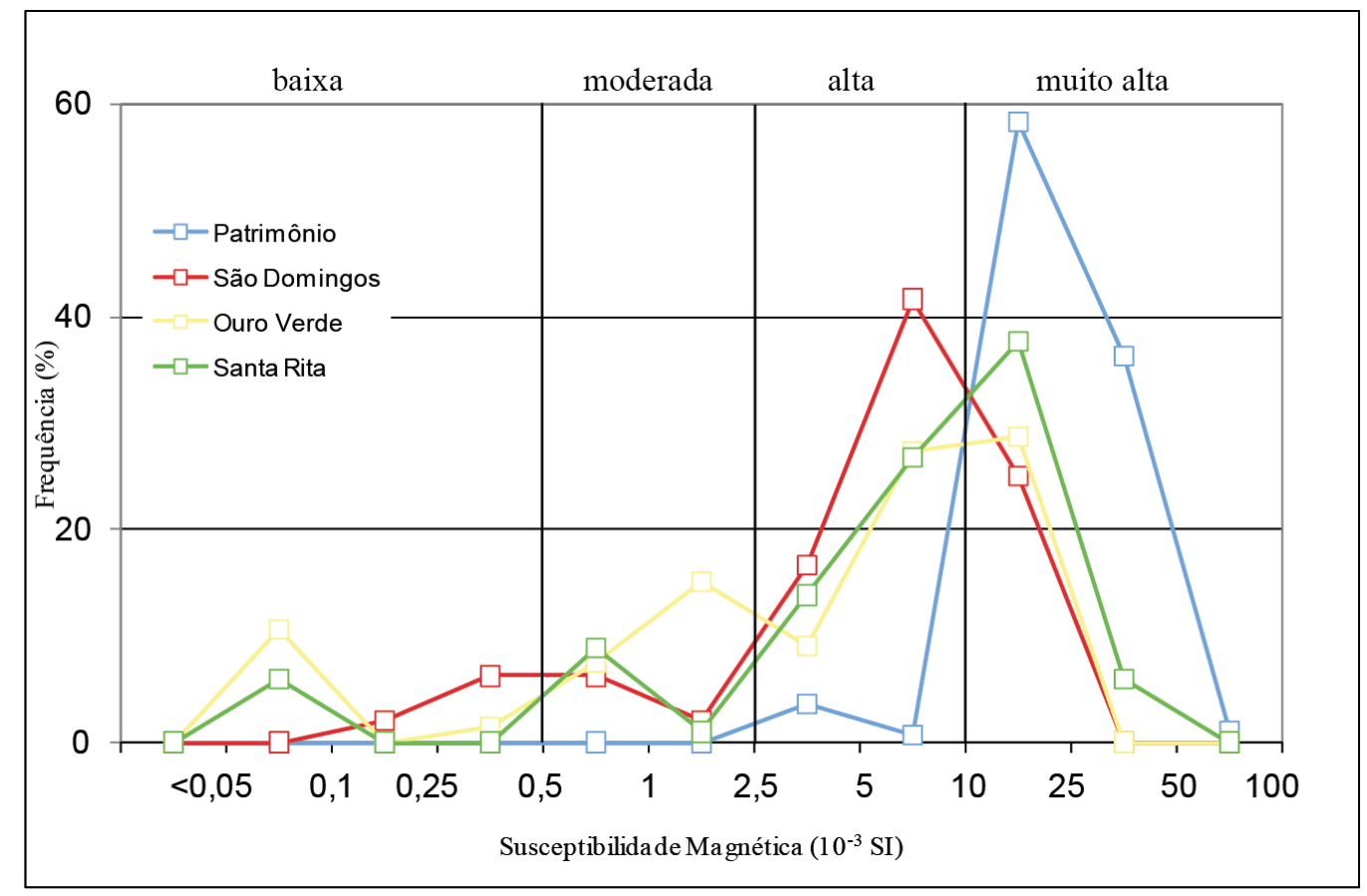

Figura 6-1: Histograma de freqüência utilizando os dados de susceptibilidade magnética (k) dos plútons da SIC

Já na relação entre susceptibilidade magnética (k) e anisotropia magnética (P) (fig .62), a última é menor no Granito Patrimônio Santo Antônio ( $\mathrm{P}=1,09$, dp. 0,04) do que nos granitos Santa Rita $(\mathrm{P}=1,23$, dp. 0,11), São Domingos $(1,21$, dp. 0,09$)$ e Ouro Verde $(\mathrm{P}=$ 1,19, dp. 0,07), apesar da sua maior susceptibilidade. Esta diferença da anisotropia do plúton Patrimônio Santo Antônio com os demais granitos pode estar relacionada à mineralogia magnética, entretanto como veremos a seguir, os minerais portadores magnéticos são essencialmente os mesmos. Ao todo não se observa uma clara relação entre estes parâmetros $(\mathrm{k}-\mathrm{P})$ no conjunto destes maciços graníticos. A única ressalva seria o Granito São Domingos, em que é possível calcular um coeficiente de correlação $\left(\mathrm{R}^{2}\right)$ de 0,51 , isto é, aproximadamente $50 \%$ dos dados podem ser explicados pela relação entre $\mathrm{k}$ e $\mathrm{P}$, em que um pequeno aumento do teor de magnetita (mudança de composição) levaria a um aumento significativo de P. O padrão mais usual para os demais é a forte variação de $\mathrm{P}$ quando $\mathrm{k}$ cresce acima de $1 \mathrm{mSI}$, que pode ser explicada por dois motivos: efeitos de interações magnéticas dos grãos ou aumento no volume modal de magnetita. No primeiro, caso a variação de $\mathrm{P}$ depende exclusivamente da textura da rocha, ou seja, do arranjo dos grãos portadores e de seu grau de proximidade, enquanto no segundo, o teor de magnetita depende da orientação preferencial dos grãos 
magnéticos. Estes dois efeitos podem combinar para produzir a extrema variação de $\mathrm{P}$ observada nos granitos Patrimônio Santo Antônio e São Domingos.
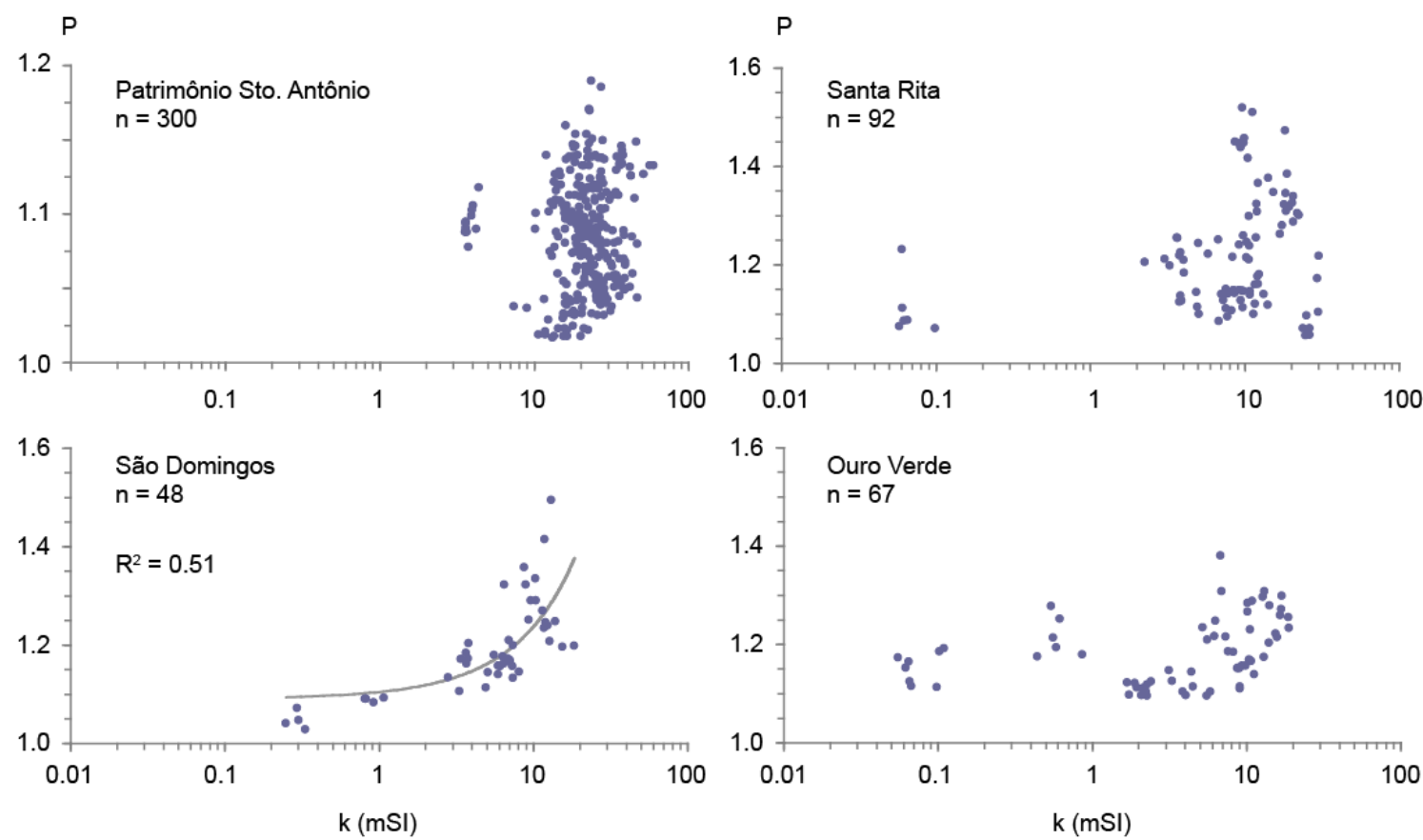

Figura 6-2: Relação entre anisotropia magnética $(P)$ e susceptibilidade magnética $(k)$ dos plútons da SIC. $n=$ número de espécimes

\subsubsection{Magnetização remanente isotérmica (IRM) e curvas termomagnéticas}

\subsubsection{Granito Patrimônio Santo Antônio}

Neste granito foram escolhidas duas amostras com susceptibilidade magnética da ordem de 18 e 25 mSI e o resultado de ambas foram semelhantes. Nos gráficos de IRM, a curva cresce rapidamente em campos indutores próximos de $0,1 \mathrm{~T}$, para em seguida permanecer constante entre $0,4<\mathrm{H} \leq 2,0 \mathrm{~T}$ (fig. 6-3). A saturação da magnetização em campo $\mathrm{H}>200$ mT indica a presença de minerais portadores com baixa coercividade. Este resultado, combinado com as curvas de variação $\mathrm{k}-\mathrm{T}$, demonstra que provavelmente este mineral é a magnetita multidomínio.

Em temperaturas baixas $\left(-200^{\circ} \mathrm{C}\right.$ a $\left.0^{\circ} \mathrm{C}\right)$ há um marcante aumento de $\mathrm{k}$ próximo a $-160^{\circ} \mathrm{C}$ relacionado à transição de Verwey. No ciclo de aquecimento e resfriamento $\left(25^{\circ} \mathrm{C}\right.$ a $\left.700^{\circ} \mathrm{C}\right)$, a anisotropia cresce progressivamente antes de cair abruptamente em $580^{\circ} \mathrm{C}$. Este crescimento regular é atribuído ao efeito Hopkinson, enquanto a forte queda em $580^{\circ} \mathrm{C}$ refere-se à 
temperatura de Curie $\left(\mathrm{T}_{\mathrm{C}}\right)$ da magnetita. A marcante transição de Verwey e a $\mathrm{T}_{\mathrm{C}}$ em $580^{\circ} \mathrm{C}$ indicam a presença de uma magnetita não alterada, relativamente "grossa" e com uma estrutura de multidomínio. A curva é praticamente reversível no ciclo de resfriamento, mostrando que o experimento ocorreu sem modificações na amostra OV44A. Já na amostra OV18A pode ter ocorrido uma pequena neoformação de minerais magnéticos.

\section{PATRIMÔNIO SANTO ANTÔNIO}
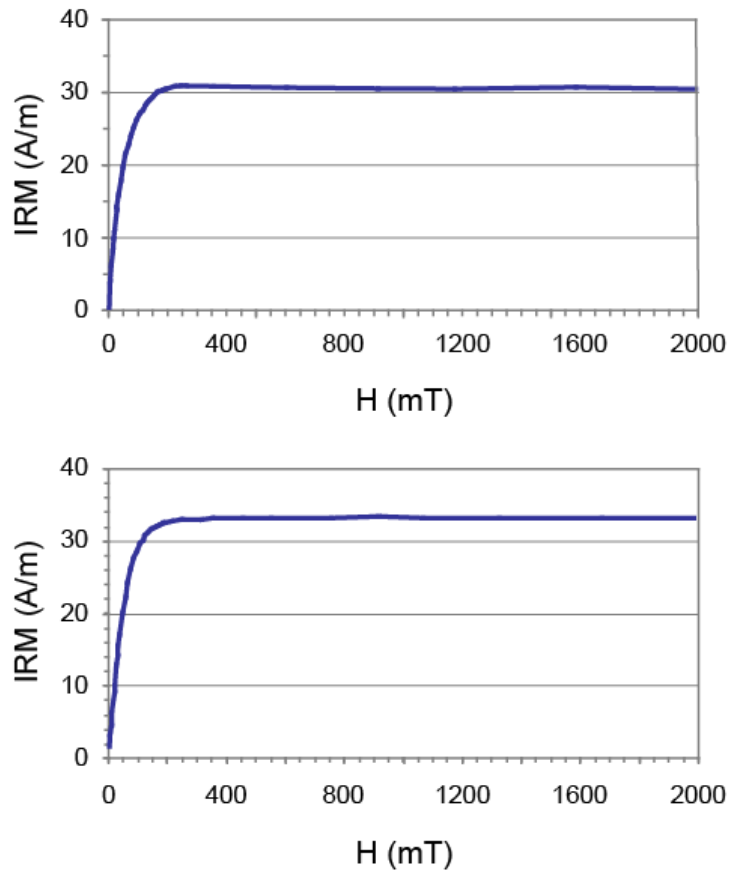
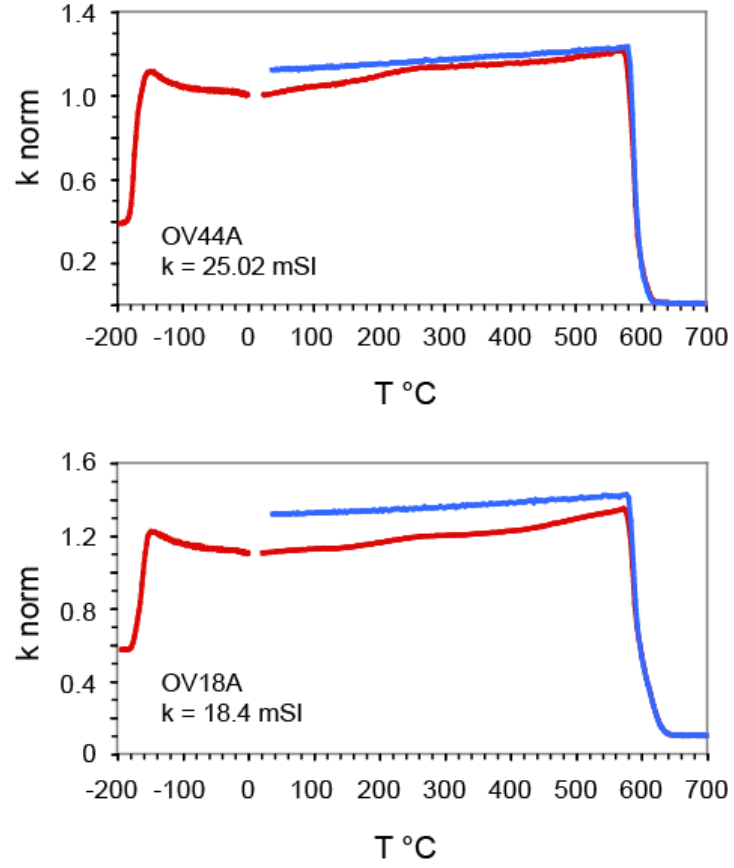

Figura 6-3: Curvas de IRM e termomagnéticas do granito Patrimônio Santo Antônio

\subsubsection{Granito Santa Rita e Ouro Verde}

Os dois granitos também apresentam valores de susceptibilidade magnética elevados, sendo que aproximadamente $44 \%$ dos espécimes do Santa Rita e $29 \%$ do Ouro Verde possuem valores de $\mathrm{k}>10 \mathrm{mSI}$. Nestes plútons o mineral ferromagnético predominante é a magnetita multidomínio.

Já os espécimes do Santa Rita e Ouro Verde com valores 2,5 < k $(\mathrm{mSI})>3,5$ diferem daqueles de alta susceptibilidade pela ocorrência de minerais ferromagnéticos de elevada coercividade, como mostrado pela insaturação da IRM em campos entre 0,5 e 2,5 T (fig. 6-4). Nas curvas termomagnéticas destaca-se o progressivo decrescimento da susceptibilidade em temperaturas acima de $600^{\circ} \mathrm{C}$ na amostra OV52C (Santa Rita), mostrando que a elevada coercividade pode estar relacionada à Ti-hematita. Já na amostra OV22B (Ouro Verde) a 
susceptibilidade sofre uma queda abrupta próximo de $580^{\circ} \mathrm{C}\left(\mathrm{T}_{\mathrm{C}}\right.$ da magnetita), indicando, juntamente com a transição de Verwey em $-160^{\circ} \mathrm{C}$ e a forte inclinação da IRM em campos induzidos entre 0 e $100 \mathrm{mT}$, a presença da magnetita. No ciclo de resfriamento de ambas as amostras a susceptibilidade final é bem maior que a susceptibilidade inicial obtida durante o aquecimento, indicando que transformações mineralógicas ocorreram no experimento. Estas modificações são facilmente identificadas pelas inflexões nas curvas de aquecimento entre $450^{\circ} \mathrm{C}$ e $560^{\circ} \mathrm{C}$ e podem ser atribuídas à transformação parcial (OV22B) ou total (OV52C) de Ti-hematita para magnetita.

\section{SANTA RITA}

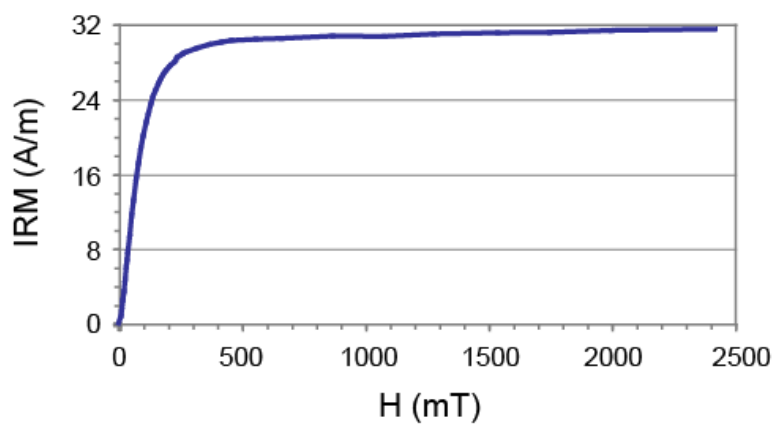

OURO VERDE

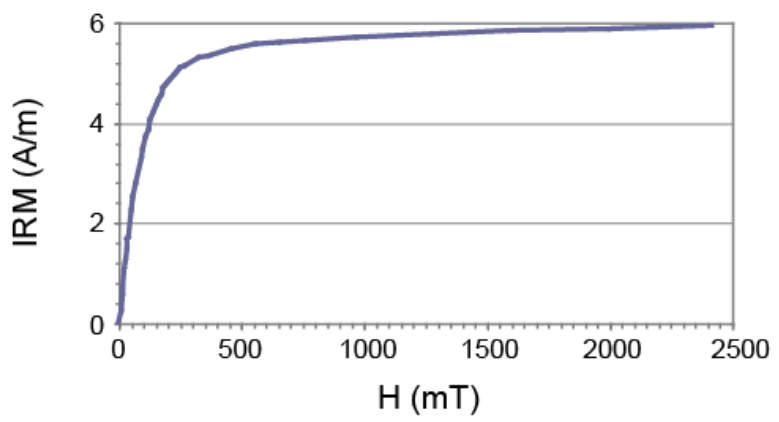

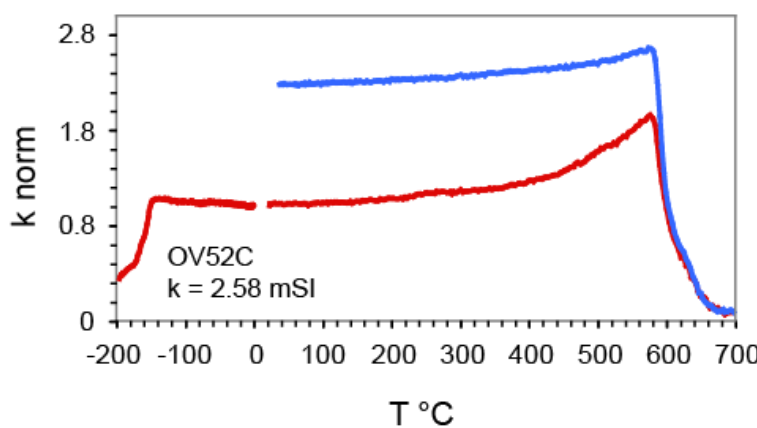

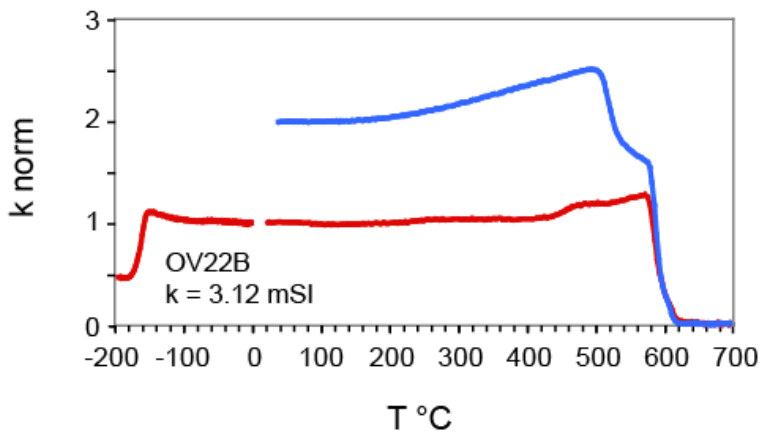

Figura 6-4: Curvas de IRM e termomagnéticas dos granitos Santa Rita e Ouro Verde 


\subsubsection{Granito São Domingos}

Neste granito foram escolhidas duas amostras com susceptibilidade entre 6,3 e 10,3 mSI e os resultados das curvas IRM e da variação k - T foram similares ao Granito Patrimônio Santo Antônio. A rocha adquire praticamente toda sua magnetização em um campo de 100 mT que, associado à transição de Verwey em $-180^{\circ} \mathrm{C}$ e à queda abrupta de $\mathrm{k}$ em $580^{\circ} \mathrm{C}$, caracteriza a presença da magnética multidomínio como principal mineral portador de magnetismo (fig. 6-5). Ainda é possível notar nas duas amostras que a susceptibilidade continua a crescer suavemente em campos acima de 0,5 $\mathrm{T}$ até próximo de 2,0 $\mathrm{T}$. Este crescimento, embora muito sutil, indica a provável ocorrência de uma fase ferromagnética de elevada coercividade não detectada na variação $\mathrm{k}$ - T e que ocorre em conjunto com a magnetita. Essa fase mineral de alta coercividade é atribuída à Ti-hematita, que também deve ser o mineral responsável pela pigmentação rosa-avermelhada observada nas amostras deste plúton. 

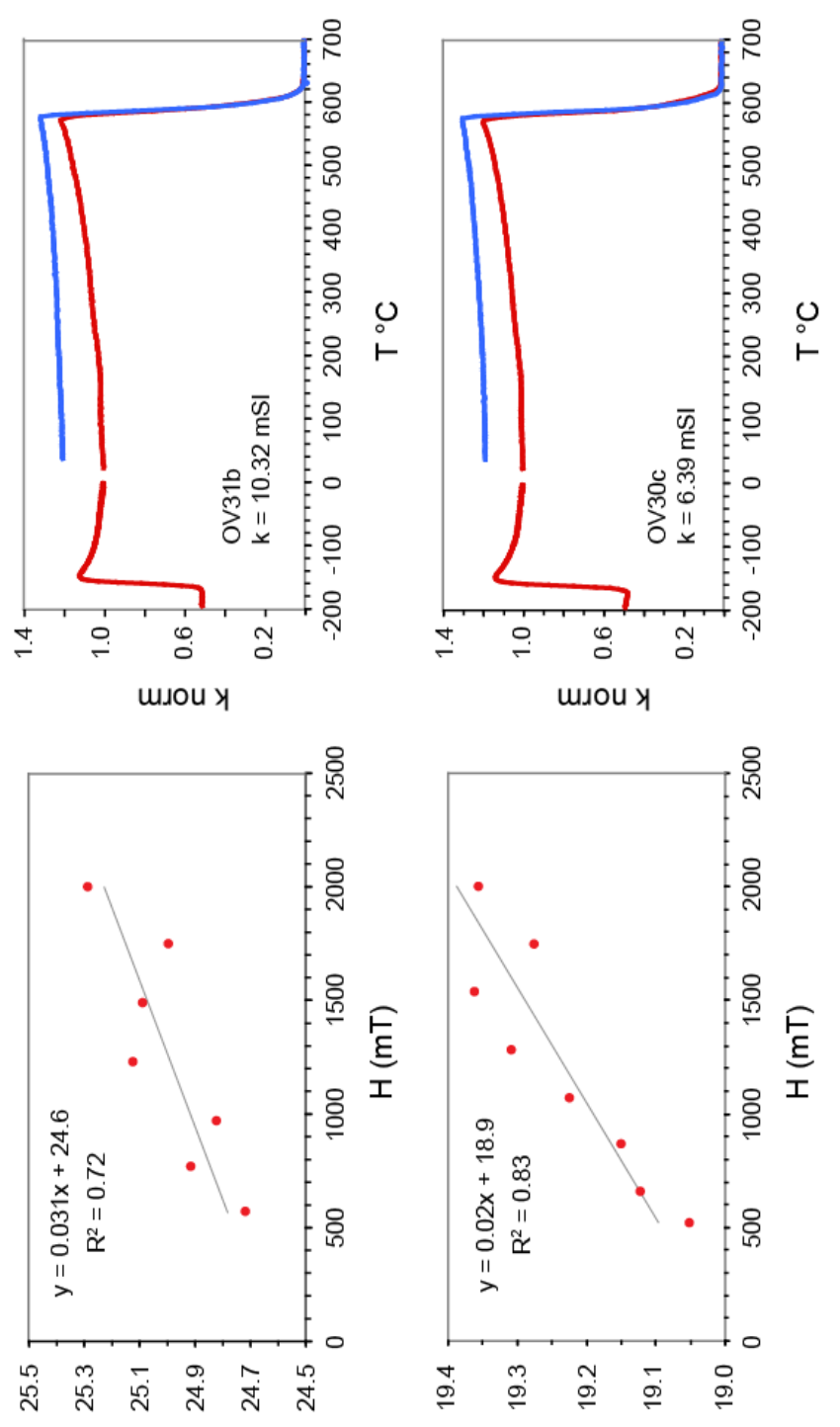

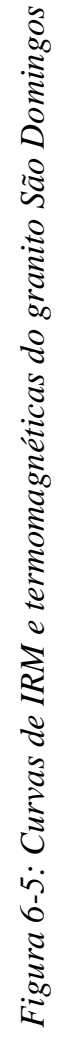

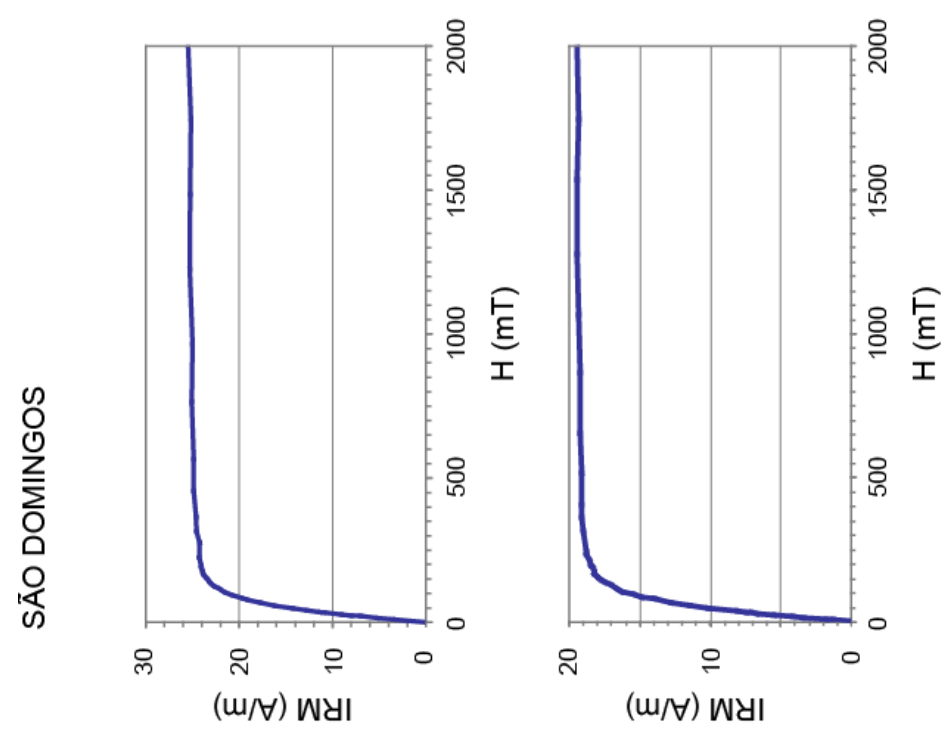




\subsection{Microscópio Eletrônico de Varredura (MEV)}

Duas amostras destes granitos foram submetidas ao microscópio eletrônico de varredura para caracterizar as microestruturas e texturas dos minerais portadores magnéticos. Como observado anteriormente pelas curvas de IRM e termomagnéticas, a magnetita é o óxido dominante nos plútons da área de estudo. Ela geralmente ocorre na forma de grãos euédricos a subédricos com tamanho médio de $100 \mu \mathrm{m}$, possuem uma superfície uniforme, e sem evidências de exsolução para ilmenita (fig. 6-6A, $C$ e D). A magnetita aparece frequentemente associada a cristais euédricos a subédricos de titanita, biotita e anfibólio. $\mathrm{Na}$ titanita é comum encontrar inclusões de titanomagnetita com forma de cristais anédricos de até $50 \mu \mathrm{m}$ de comprimento (fig. 6-6B). Os contatos da titanomagnetita são encurvados a embainhados e geralmente as faixas com maior proporção de titânio (Ti) ocorrem paralelas ao maior comprimento do grão.
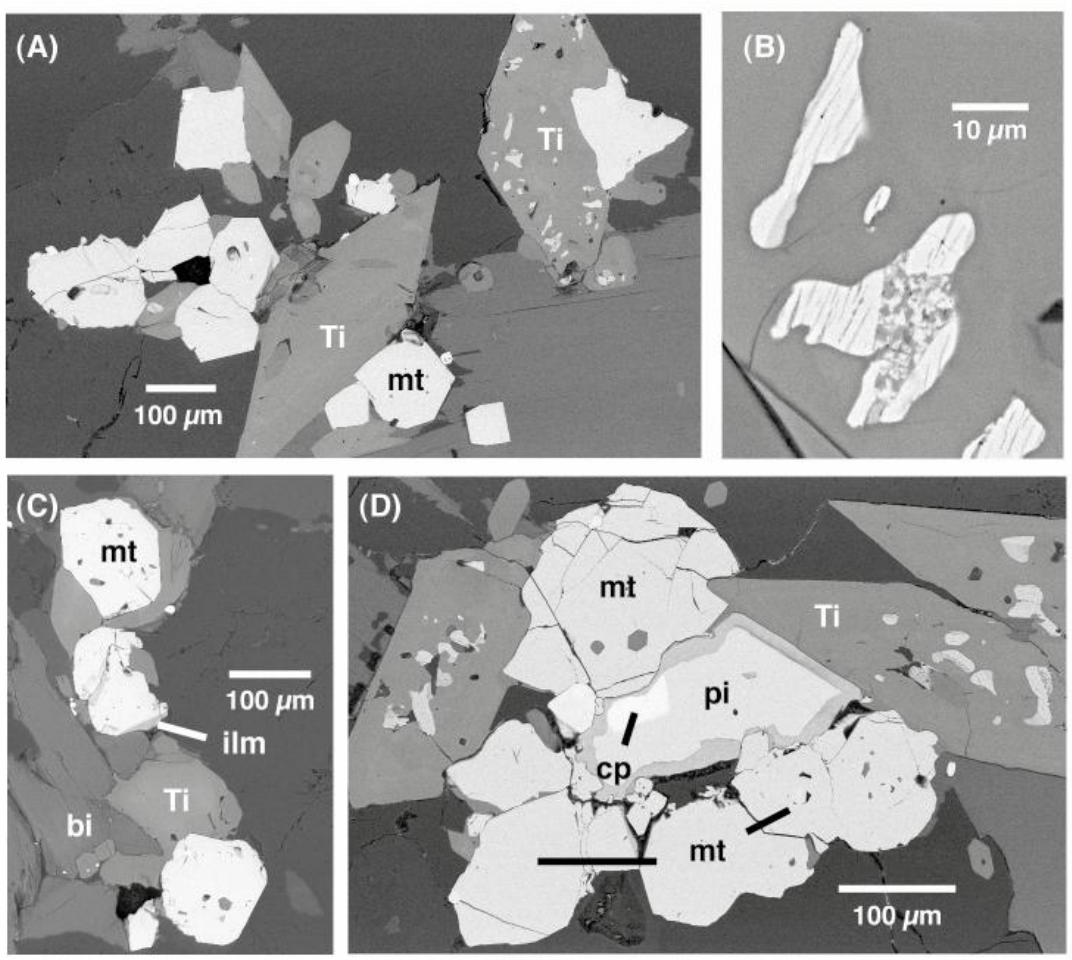

Figura 6-6: Textura de óxidos de Fe e Ti na SIC. (A) Cristais de magnetita (mt) associado a titanita (Ti); detalhe para a presença de inclusões nas bordas do cristal do titanita. (B) Detalhe de grãos de titanomagnetita inclusos em titanita. Faixas mais escuras, com maior proporção de titânio, alternadas com faixas mais claras com maior proporção de Fe. (C) Associação magnetita, ilmenita, titanita e biotita com contatos retos e encurvados indicativos da cristalização em equilíbrio. A ilmenita (ilm) forma pequenos cristais alongados na borda da magnetita. (D) Cristais de magnetita ( $\mathrm{mt}$ ) e titanita (Ti) envolvendo sulfetos: pirita (pi) e calcopirita (сp). A pirita exibe uma "borda de reação" com aspecto homogêneo formada por ferro e níquel. Detalhe para a presença novamente de titanomagnetita anédrica inclusa na titanita 
Já os grãos contendo faixas diferenciadas e alternadas, ora com maior proporção de Ti e ora com maior proporção de Fe, são encontrados somente nos óxidos aprisionados pela titanita. Esta relação provavelmente foi formada por um processo de exsolução durante o resfriamento magmático. Por outro lado, quando em contato com a matriz silicatada, os óxidos de $\mathrm{Fe}$ e Ti são completamente desagregados para formar cristais individuais de magnetita e ilmenita. Além destes minerais, também foram encontrados subordinadamente cristais de pirita e calcopirita (fig. 6-6D), queocorrem como grãos subédricos e podem atingir até $100 \mu \mathrm{m}$ de comprimento. Suas relações texturais indicam que os óxidos e os sulfetos de ferro se cristalizaram com os silicatos, ou seja, eles não são produtos de alteração em temperatura mais baixa. 


\section{Trama Magnética}

Neste capitulo serão apresentados os dados de anisotropia de susceptibilidade magnética (ASM) referente aos aos plútons da SIC. A representação espacial dos dados de ASM é normalmente realizada em uma projeção estereográfica (hemisfério inferior). As direções principais da trama magnética são representadas pela susceptibilidade máxima $\left(\mathrm{k}_{1}\right)$ e mínima $\left(\mathrm{k}_{3}\right)$, sendo correlacionadas respectivamente a lineação magnética e a foliação magnética. A trama magnética pode ser classificada de três formas: linear, planar e triaxial ou planolinear (fig. 7-1). Na trama linear, que possui apenas a lineação magnética definida, os eixos $\mathrm{k}_{1}-\mathrm{k}_{1 \mathrm{~A}}$ estão agrupados, enquanto $\mathrm{k}_{2}-\mathrm{k}_{2 \mathrm{~A}}$ e $\mathrm{k}_{3}-\mathrm{k}_{3 \mathrm{~A}}$ estão distribuídos em um plano normal a $\mathrm{k}_{1}$ $\mathrm{k}_{1 \mathrm{~A}}$. Já a trama planar possui apenas a foliação magnética definida e os eixos $\mathrm{k}_{1}-\mathrm{k}_{1 \mathrm{~A}}$ e $\mathrm{k}_{2}-\mathrm{k}_{2 \mathrm{~A}}$ encontram-se distribuídos em um plano normal a $\mathrm{k}_{3}-\mathrm{k}_{3 \mathrm{~A}}$ (pólo da foliação). Em uma trama triaxial ou plano-linear, todos os eixos do elipsóide formam agrupamentos distintos $\left(\mathrm{k}_{1}>\mathrm{k}_{2}>\mathrm{k}_{3}\right)$.

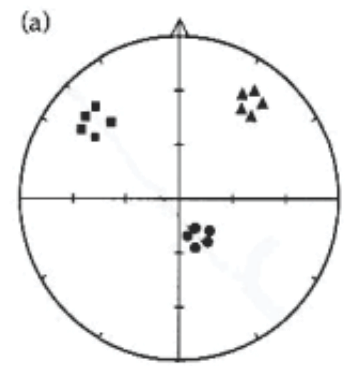

- Eixo prinçipal máximo, $\mathbf{K}_{1}$

4. Eixo prineipal intermediârio ${ }_{8} \mathrm{~K}$

- Eixó prineipal mininimo, K
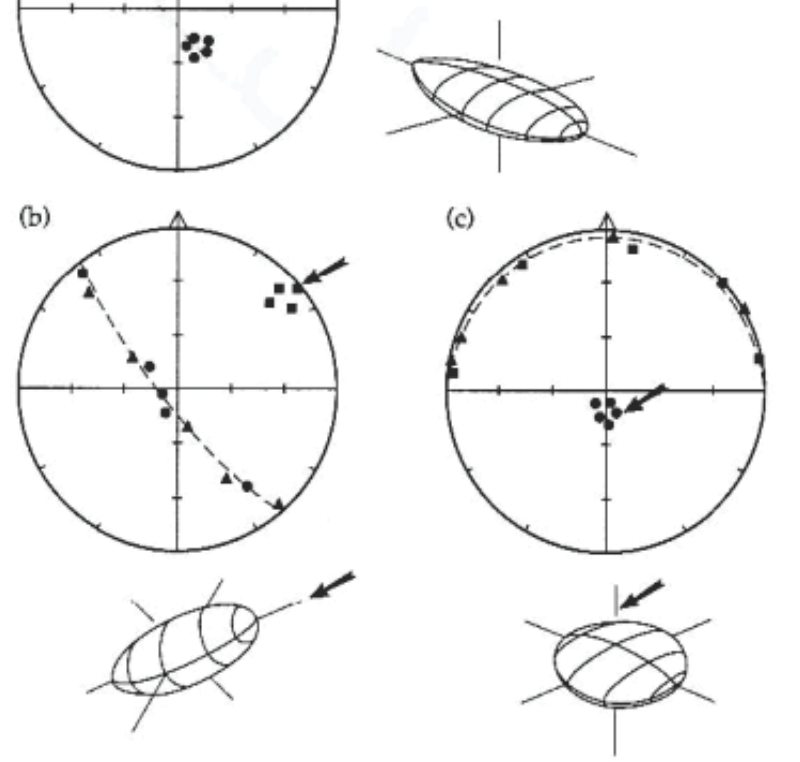

Figura 7-1: Representação espacial da trama magnética. A distribuição é considerada triaxial ou plano-linear $(a)$, linear $(b)$ e planar $(c)$ dependendo dos arranjos dos eixos máximo $\left(k_{1}, k_{1 A}\right)$, intermediário $\left(k_{2}, k_{2 A}\right)$ e mínimo $\left(k_{3}, k_{3 A}\right)$ 


\subsection{Amostragem}

No total foram amostradas 70 estações de ASM, cuja distribuição é mostrada na figura 7-2. Em cada estação foram coletadas entre 6 e 12 espécimes, o que contribuiu para um total de 507 espécimes orientados (uma média de 7 espécimes por estação) destinados à caracterização da mineralogia e da trama magnética. Os parâmetros escalares e direcionais dos granitos da Suíte Intrusiva Cunhaporanga (SIC) estão listados na Tabela 2. Para caracterizar a forma do elipsóide (T) e o grau de anisotropia (P) utilizaram-se os parâmetros de Jelinek (1981).

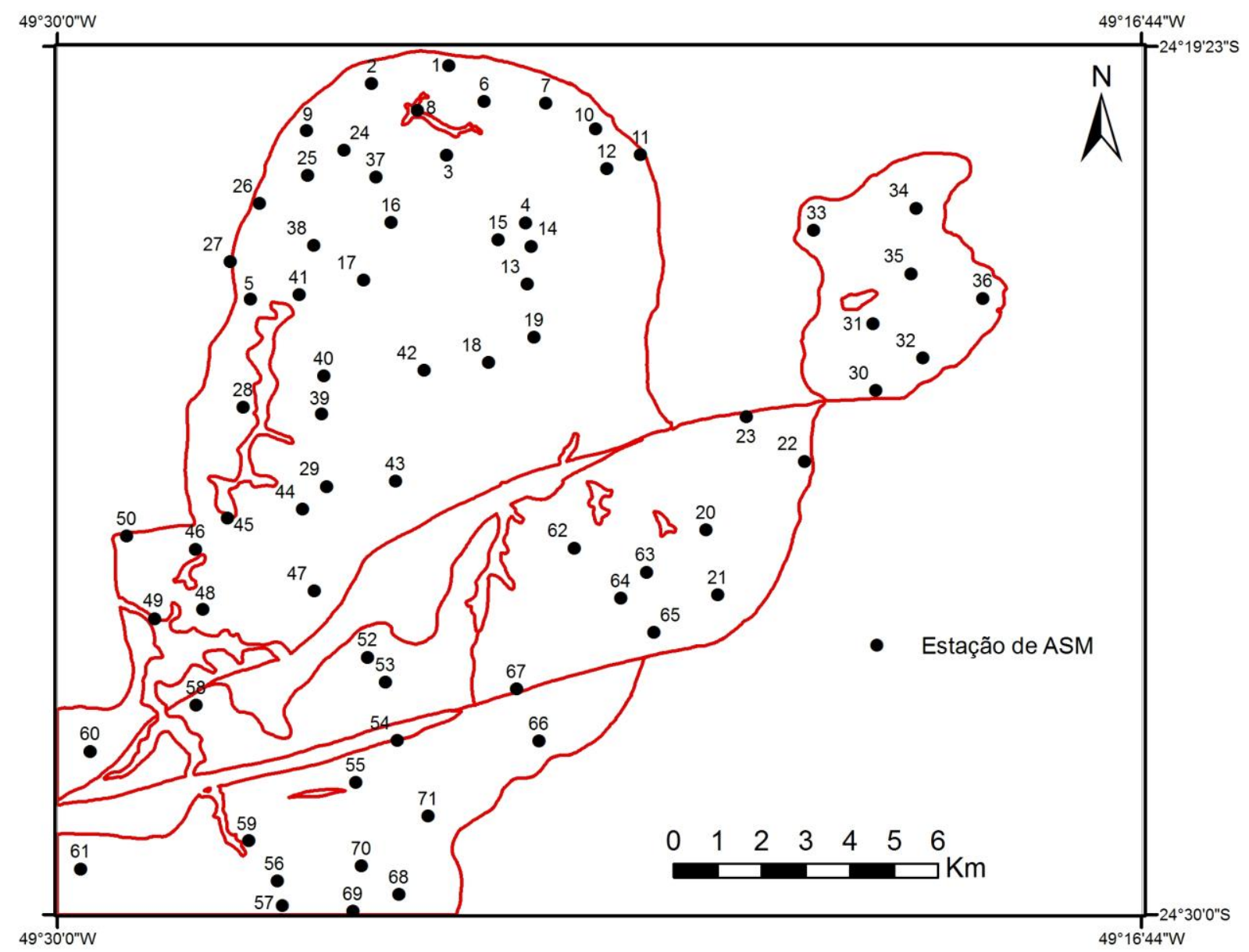

Figura 7-2: Estações de amostragem para medida de anisotropia de susceptibilidade magnética (ASM) da Suíte Intrusiva Cunhaporanga 


\subsection{Dados de anisotropia de susceptibilidade magnética}

Tabela 2 - Parâmetros da ASM dos granitos da SIC na área de estudo

\begin{tabular}{|c|c|c|c|c|c|c|c|c|c|c|c|c|c|c|c|}
\hline \multicolumn{2}{|c|}{ UTM } & \multirow[b]{2}{*}{ Estação } & \multirow[b]{2}{*}{$\mathrm{n}$} & \multirow[b]{2}{*}{$\mathrm{k}(\mathrm{mSI})$} & \multirow[b]{2}{*}{$\mathrm{P}$} & \multirow[b]{2}{*}{$\mathrm{T}$} & \multicolumn{3}{|c|}{ k1 } & \multicolumn{3}{|c|}{ k2 } & \multicolumn{3}{|c|}{ k3 } \\
\hline $\mathrm{X}$ & $\mathrm{Y}$ & & & & & & Dec & Inc & $\alpha 1$ & Dec & Inc & $\alpha 2$ & Dec & Inc & $\alpha 3$ \\
\hline 660289 & 7308681 & OV01 & 9 & 14,00 & 1,031 & 0,10 & 62 & 45 & 13,4 & 249 & 45 & 42,9 & 156 & 3 & 42,8 \\
\hline 658687 & 7308297 & OV02 & 7 & 21,30 & 1,033 & 0,03 & 220 & 18 & 36,3 & 290 & 6 & 37,2 & 182 & 71 & 22,3 \\
\hline 660228 & 7306662 & OV03 & 14 & 26,10 & 1,055 & 0,12 & 338 & 10 & 25,2 & 81 & 49 & 23,8 & 240 & 39 & 16,9 \\
\hline 661837 & 7305115 & OV04 & 7 & 23,80 & 1,135 & $-0,34$ & 158 & 6 & 5,7 & 62 & 49 & 14,4 & 253 & 40 & 13,6 \\
\hline 656129 & 7303451 & OV05 & 8 & 21,60 & 1,080 & $-0,16$ & 195 & 11 & 27,9 & 95 & 42 & 25,1 & 297 & 46 & 16,5 \\
\hline 661015 & 7307867 & OV06 & 7 & 16,30 & 1,038 & $-0,07$ & 167 & 20 & 26,1 & 34 & 61 & 41,6 & 265 & 19 & 43,1 \\
\hline 662286 & 7307816 & OV07 & 6 & 15,60 & 1,095 & $-0,06$ & 127 & 2 & 3,8 & 223 & 76 & 5,2 & 37 & 14 & 4,9 \\
\hline 659638 & 7307680 & OV08 & 7 & 21,10 & 1,034 & $-0,22$ & 169 & 2 & 42,6 & 75 & 60 & 43,1 & 260 & 29 & 28,8 \\
\hline 657329 & 7307254 & OV09 & 6 & 20,40 & 1,043 & 0,08 & 188 & 3 & 14,9 & 279 & 16 & 19,2 & 88 & 73 & 19,2 \\
\hline 663315 & 7307216 & OV10 & 8 & 14,50 & 1,112 & 0,01 & 322 & 4 & 10,8 & 57 & 56 & 12,9 & 230 & 34 & 14,9 \\
\hline 664235 & 7306624 & OV11 & 9 & 16,50 & 1,126 & $-0,25$ & 353 & 13 & 10,5 & 97 & 46 & 10,7 & 251 & 41 & 7,9 \\
\hline 663538 & 7306312 & OV12 & 6 & 19,60 & 1,151 & 0,06 & 335 & 5 & 8,5 & 72 & 57 & 13,2 & 242 & 32 & 11,3 \\
\hline 661861 & 7303729 & OV13 & 6 & 18,60 & 1,123 & $-0,38$ & 301 & 5 & 24,6 & 34 & 24 & 32,5 & 199 & 66 & 25,4 \\
\hline 661951 & 7304583 & OV14 & 8 & 21,10 & 1,142 & $-0,39$ & 346 & 8 & 11,3 & 81 & 34 & 9,4 & 245 & 54 & 8,6 \\
\hline 661267 & 7304733 & OV15 & 8 & 28,00 & 1,115 & $-0,32$ & 316 & 3 & 17,8 & 48 & 32 & 17,2 & 221 & 58 & 10,4 \\
\hline 659058 & 7305152 & OV16 & 6 & 31,70 & 1,069 & 0,09 & 358 & 6 & 16,3 & 90 & 14 & 19,7 & 246 & 74 & 19,1 \\
\hline 658476 & 7303858 & OV17 & 7 & 15,20 & 1,087 & $-0,10$ & 137 & 6 & 25,5 & 227 & 1 & 25,9 & 322 & 84 & 7,2 \\
\hline 661037 & 7301969 & OV18 & 8 & 19,40 & 1,088 & $-0,10$ & 303 & 6 & 15,9 & 211 & 18 & 16,5 & 51 & 71 & 6,5 \\
\hline 661984 & 7302523 & OV19 & 8 & 35,90 & 1,137 & 0,16 & 306 & 6 & 10,8 & 38 & 16 & 9,1 & 197 & 73 & 6,3 \\
\hline 665493 & 7298129 & OV20 & 7 & 2,56 & 1,112 & 0,01 & 7 & 28 & 18,3 & 121 & 38 & 13,2 & 251 & 40 & 15,5 \\
\hline 665718 & 7296661 & OV21 & 7 & 6,32 & 1,256 & $-0,39$ & 357 & 8 & 13,2 & 95 & 42 & 14,8 & 259 & 46 & 13,8 \\
\hline 667551 & 7299658 & OV22 & 9 & 2,96 & 1,116 & 0,36 & 22 & 14 & 16,6 & 196 & 76 & 16,4 & 292 & 1 & 12,5 \\
\hline 666353 & 7300676 & OV23 & 7 & 16,50 & 1,238 & $-0,06$ & 323 & 25 & 6,1 & 67 & 27 & 7,4 & 197 & 51 & 7,7 \\
\hline 658099 & 7306795 & OV24 & 9 & 31,20 & 1,052 & 0,23 & 10 & 19 & 17,6 & 105 & 13 & 18,2 & 228 & 67 & 15,4 \\
\hline 657340 & 7306237 & OV25 & 6 & 40,00 & 1,059 & $-0,07$ & 178 & 3 & 12,5 & 271 & 35 & 15,7 & 84 & 55 & 14,4 \\
\hline 656342 & 7305612 & OV26 & 6 & 32,20 & 1,059 & $-0,18$ & 353 & 38 & 21,4 & 126 & 40 & 31,9 & 241 & 26 & 31,5 \\
\hline 655723 & 7304302 & OV27 & 8 & 36,20 & 1,059 & $-0,31$ & 17 & 43 & 7,9 & 152 & 38 & 21,1 & 262 & 24 & 21,0 \\
\hline 655950 & 7301012 & OV28 & 6 & 38,60 & 1,112 & $-0,59$ & 200 & 20 & 7,2 & 63 & 63 & 13,4 & 297 & 16 & 13,6 \\
\hline 657654 & 7299201 & OV29 & 6 & 48,20 & 1,135 & $-0,17$ & 225 & 4 & 29,1 & 132 & 31 & 28,3 & 321 & 58 & 12,5 \\
\hline 669035 & 7301239 & OV30 & 7 & 6,80 & 1,176 & $-0,46$ & 356 & 24 & 26,9 & 262 & 10 & 32,1 & 150 & 64 & 23,0 \\
\hline 669004 & 7302743 & OV31 & 6 & 10,70 & 1,265 & $-0,64$ & 8 & 16 & 8,3 & 102 & 15 & 16,9 & 232 & 6 & 16,9 \\
\hline 670023 & 7301966 & OV32 & 6 & 13,10 & 1,212 & $-0,66$ & 342 & 38 & 18,7 & 83 & 13 & 18,2 & 189 & 49 & 9,2 \\
\hline 667802 & 7304874 & OV33 & 9 & 5,89 & 1,144 & $-0,74$ & 353 & 25 & 21,0 & 260 & 7 & 22,6 & 156 & 64 & 19,8 \\
\hline 669923 & 7305350 & OV34 & 6 & 3,49 & 1,172 & $-0,58$ & 358 & 15 & 8,3 & 110 & 56 & 18,8 & 259 & 30 & 18,8 \\
\hline 669804 & 7303870 & OV35 & 6 & 9,84 & 1,375 & $-0,76$ & 355 & 20 & 3,1 & 91 & 15 & 4,9 & 214 & 65 & 4,8 \\
\hline 671275 & 7303296 & OV36 & 8 & 0,60 & 1,069 & $-0,18$ & 316 & 18 & 12,1 & 84 & 62 & 28,0 & 219 & 20 & 28,3 \\
\hline 658755 & 7306186 & OV37 & 6 & 28,00 & 1,044 & 0,24 & 212 & 4 & 22,7 & 308 & 61 & 35,5 & 119 & 29 & 33,2 \\
\hline
\end{tabular}




\begin{tabular}{|c|c|c|c|c|c|c|c|c|c|c|c|c|c|c|c|}
\hline \multicolumn{2}{|c|}{ UTM } & \multirow[b]{2}{*}{ Estação } & \multirow[b]{2}{*}{$\mathrm{n}$} & \multirow[b]{2}{*}{$\mathrm{k}(\mathrm{mSI})$} & \multirow[b]{2}{*}{$\mathrm{P}$} & \multirow[b]{2}{*}{$\mathrm{T}$} & \multicolumn{3}{|c|}{$\mathrm{k} 1$} & \multicolumn{3}{|c|}{$\mathrm{k} 2$} & \multicolumn{3}{|c|}{ k3 } \\
\hline $\mathbf{X}$ & $\mathrm{Y}$ & & & & & & Dec & Inc & $\alpha 1$ & Dec & Inc & $\alpha 2$ & Dec & Inc & $\alpha 3$ \\
\hline 657450 & 7304651 & OV38 & 7 & 26,40 & 1,074 & 0,21 & 11 & 8 & 23,7 & 106 & 29 & 23,7 & 267 & 60 & 6,9 \\
\hline 657577 & 7300846 & OV39 & 11 & 3,82 & 1,095 & 0,23 & 125 & 22 & 13,9 & 224 & 21 & 12,4 & 355 & 59 & 7,4 \\
\hline 657630 & 7301699 & OV40 & 6 & 12,60 & 1,021 & $-0,01$ & 222 & 36 & 13,1 & 325 & 17 & 15,9 & 75 & 48 & 13,0 \\
\hline 657135 & 7303547 & OV41 & 8 & 28,00 & 1,075 & 0,36 & 159 & 53 & 10,2 & 27 & 26 & 11,9 & 285 & 24 & 10,5 \\
\hline 659704 & 7301804 & OV42 & 8 & 21,10 & 1,118 & 0,10 & 166 & 3 & 16,6 & 75 & 9 & 16,7 & 275 & 81 & 7,3 \\
\hline 659084 & 7299302 & OV43 & 9 & 22,80 & 1,074 & 0,26 & 152 & 7 & 11,4 & 243 & 12 & 11,2 & 31 & 76 & 7,3 \\
\hline 657150 & 7298690 & OV44 & 10 & 24,60 & 1,085 & 0,14 & 148 & 9 & 29,0 & 58 & 2 & 29,2 & 317 & 81 & 8,2 \\
\hline 655598 & 7298512 & OV45 & 7 & 24,10 & 1,106 & $-0,38$ & 121 & 7 & 4,6 & 30 & 9 & 14,4 & 247 & 79 & 14,6 \\
\hline 654937 & 7297815 & OV46 & 6 & 20,30 & 1,095 & $-0,68$ & 80 & 5 & 79,1 & 349 & 4 & 79,1 & 220 & 83 & 13,4 \\
\hline 657374 & 7296840 & OV47 & 6 & 19,10 & 1,059 & 0,07 & 166 & 4 & 7,5 & 259 & 37 & 10,2 & 71 & 52 & 7,9 \\
\hline 655065 & 7296457 & OV48 & 7 & 19,40 & 1,103 & 0,02 & 144 & 2 & 12,8 & 234 & 16 & 15,2 & 46 & 74 & 9,8 \\
\hline 654067 & 7296256 & OV49 & 6 & 22,10 & 1,095 & $-0,59$ & 144 & 22 & 12,4 & 237 & 8 & 14,8 & 346 & 67 & 15,0 \\
\hline 653509 & 7298129 & OV50 & 7 & 23,10 & 1,137 & $-0,43$ & 173 & 11 & 11,9 & 289 & 66 & 13,9 & 79 & 21 & 14,9 \\
\hline 658460 & 7295333 & OV52 & 7 & 3,84 & 1,214 & 0,35 & 315 & 16 & 25,1 & 220 & 19 & 25,3 & 83 & 65 & 9,6 \\
\hline 658827 & 7294764 & OV53 & 8 & 8,60 & 1,240 & 0,61 & 355 & 1 & 13,8 & 85 & 26 & 13,9 & 264 & 64 & 5,4 \\
\hline 659052 & 7293444 & OV54 & 9 & 13,10 & 1,144 & $-0,15$ & 331 & 15 & 13,6 & 71 & 34 & 18,8 & 220 & 51 & 19,0 \\
\hline 658181 & 7292512 & OV55 & 7 & 12,40 & 1,319 & 0,12 & 346 & 6 & 5,9 & 80 & 31 & 6,0 & 247 & 58 & 5,5 \\
\hline 656541 & 7290303 & OV56 & 8 & 9,75 & 1,461 & 0,24 & 345 & 31 & 5,4 & 116 & 47 & 5,3 & 238 & 26 & 2,2 \\
\hline 656605 & 7289413 & OV57 & 6 & 1,94 & 1,150 & 0,01 & 147 & 17 & 4,5 & 45 & 33 & 5,4 & 260 & 52 & 3,5 \\
\hline 654910 & 7294292 & OV58 & 6 & 25,90 & 1,077 & $-0,27$ & 174 & 1 & 16,4 & 264 & 31 & 16,8 & 83 & 59 & 7,8 \\
\hline 655962 & 7291217 & OV59 & 8 & 19,10 & 1,326 & $-0,63$ & 347 & 7 & 4,0 & 80 & 23 & 6,8 & 83 & 59 & 7,8 \\
\hline 652708 & 7293271 & OV60 & 10 & 19,50 & 1,556 & $-0,24$ & 148 & 18 & 2,5 & 240 & 6 & 3,2 & 347 & 70 & 3,2 \\
\hline 652482 & 7290615 & OV61 & 7 & 15,00 & 1,309 & $-0,42$ & 330 & 6 & 4,9 & 230 & 61 & 10,2 & 63 & 29 & 10,3 \\
\hline 662769 & 7297751 & OV62 & 9 & 9,90 & 1,152 & $-0,18$ & 355 & 18 & 8,7 & 263 & 6 & 9,5 & 154 & 71 & 5,2 \\
\hline 664248 & 7297179 & OV63 & 6 & 0,60 & 1,216 & $-0,07$ & 325 & 5 & 25,6 & 56 & 11 & 25,5 & 211 & 77 & 26,4 \\
\hline 663711 & 7296604 & OV64 & 6 & 7,51 & 1,150 & $-0,11$ & 319 & 8 & 16,5 & 224 & 31 & 21,0 & 61 & 57 & 17,2 \\
\hline 664393 & 7295831 & OV65 & 8 & 12,30 & 1,282 & 0,13 & 345 & 17 & 12,8 & 79 & 11 & 12,0 & 200 & 69 & 7,4 \\
\hline 661987 & 7293401 & OV66 & 6 & 0,07 & 1,111 & $-0,01$ & 35 & 31 & 23,1 & 224 & 59 & 41,4 & 128 & 4 & 44,0 \\
\hline 661539 & 7294583 & OV67 & 8 & 0,08 & 1,153 & $-0,16$ & 350 & 21 & 7,2 & 205 & 65 & 19,4 & 85 & 13 & 19,7 \\
\hline 659051 & 7289963 & OV68 & 6 & 4,49 & 1,145 & $-0,14$ & 290 & 78 & 26,6 & 190 & 2 & 47,1 & 99 & 12 & 44,5 \\
\hline 658101 & 7289601 & OV69 & 6 & 7,89 & 1,136 & 0,16 & 57 & 17 & 29,0 & 147 & 1 & 29,8 & 241 & 73 & 12,9 \\
\hline 658283 & 7290624 & OV70 & 6 & 11,20 & 1,120 & 0,12 & 12 & 11 & 7,8 & 111 & 36 & 11,3 & 267 & 52 & 8,8 \\
\hline 659668 & 7291728 & OV71 & 8 & 10,70 & 1,158 & $-0,17$ & 6 & 13 & 6,0 & 111 & 46 & 18,6 & 264 & 41 & 18,2 \\
\hline
\end{tabular}

$k$, susceptibilidade magnética (10-3 SI) média de cada estação; $P$, grau de anisotropia; T, parâmetro de forma; $k 1, k 2$ e $k 3$ são as direções principais médias (dec = declinação, inc = inclinação) da estação, enquanto $\alpha 1, \alpha 2$ e a3 são os semi-ângulos dos cones de confiança (95\%) em torno das respectivas direções médias; n, número de espécimes. 


\subsection{Parâmetros escalares (anisotropia e forma do elipsóide)}

A susceptibilidade magnética dos quatro plútons na área de estudo é bastante elevada, sendo que mais de $70 \%$ dos espécimes apresentam $\mathrm{k} \geq 10 \mathrm{mSI}$. Essa forte susceptibilidade é distribuída em todos os granitos da área e o principal mineral magnético é a magnetita multidomínio. A distribuição da anisotropia magnética (fig. 7-3) destes granitos evidencia um comportamento anisotrópico crescente de NNW para SSE.

O Granito Patrimônio Santo Antônio apresenta em sua porção NNW valores de $\mathrm{P}<$ 1,05 que aumentam gradativamente em direção ao centro do corpo até a extrema borda sul e sudeste, esta formada pelo forte padrão anisotrópico $(\mathrm{P}>1,20)$ proporcionado pelo conjunto dos granitos São Domingos, Santa Rita e Ouro Verde. Vale lembrar que a borda sudeste está localizada próxima da Zona de Cisalhamento Itapirapuã, o que pode indicar uma provável explicação para essa forte anisotropia magnética. Os resultados dos parâmetros escalares foram individualizados para cada granito e serão apresentados a seguir.

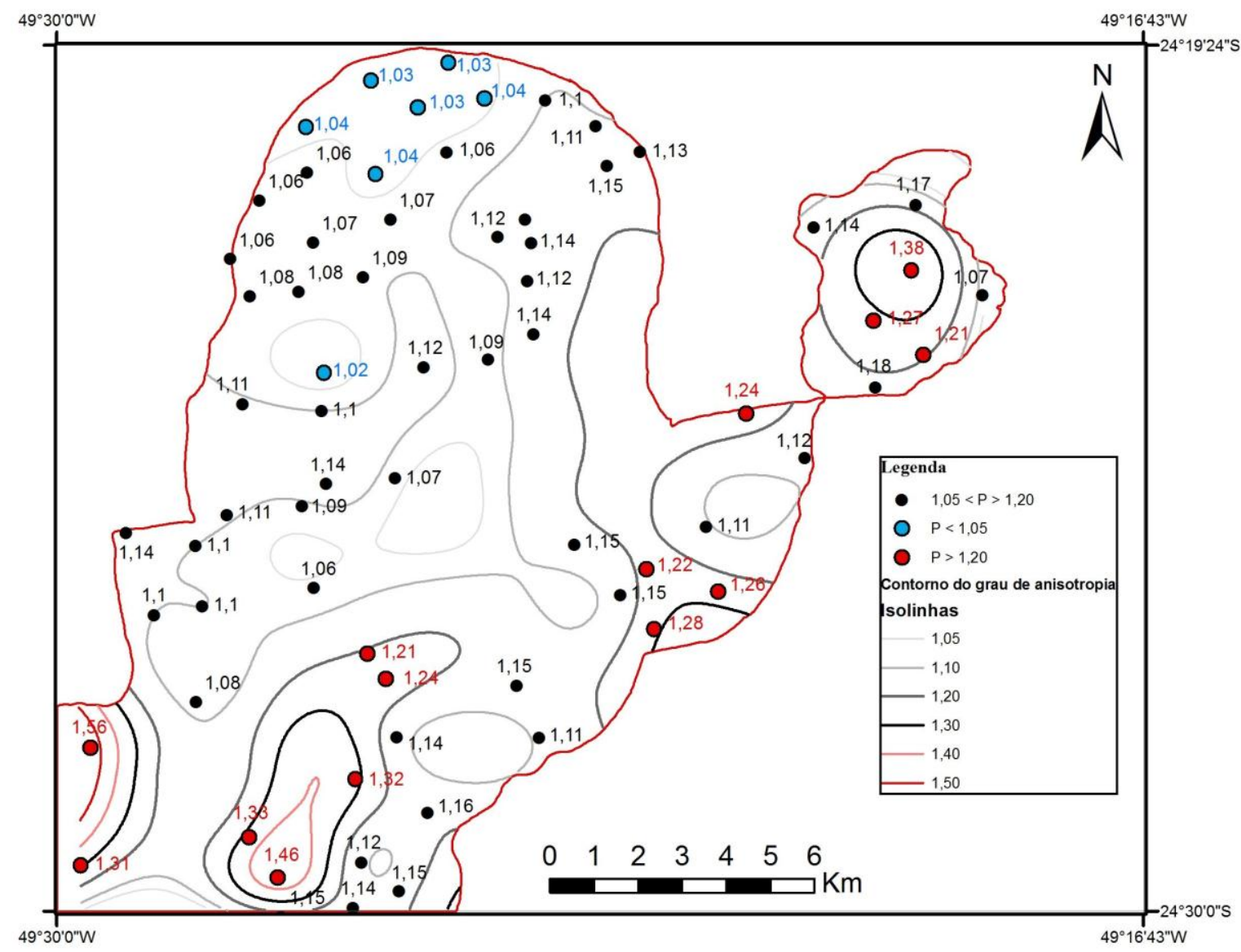

Figura 7-3: Distribuição da anisotropia de susceptibilidade magnética média $(P)$ de cada estação para os granitos da área de estudo. O grau de anisotropia é menor na porção NNW e maior na região SSE 


\subsubsection{Granito Patrimônio Santo Antônio}

Nesse granito foram coletadas 40 estações de ASM (300 espécimes) que estão distribuídas em uma malha regular com espaçamento de aproximadamente $1 \mathrm{~km}$ entre as estações. Esse plúton apresenta a maior susceptibilidade magnética entre os granitos estudados, com valor de k da ordem de 23,2 mSI, entretanto sua anisotropia magnética média é a mais baixa, com $\mathrm{P}=1,09(\mathrm{dp}=0,04)$. Aproximadamente mais de $60 \%$ dos espécimes apresentam valores de $\mathrm{P}$ inferiores a 1,10. Quanto à forma do elipsóide, 18\% são oblatos (T > $0,25)$, enquanto $30 \%$ são prolatos $(\mathrm{T}<-0,25)$ (fig. 7-4).
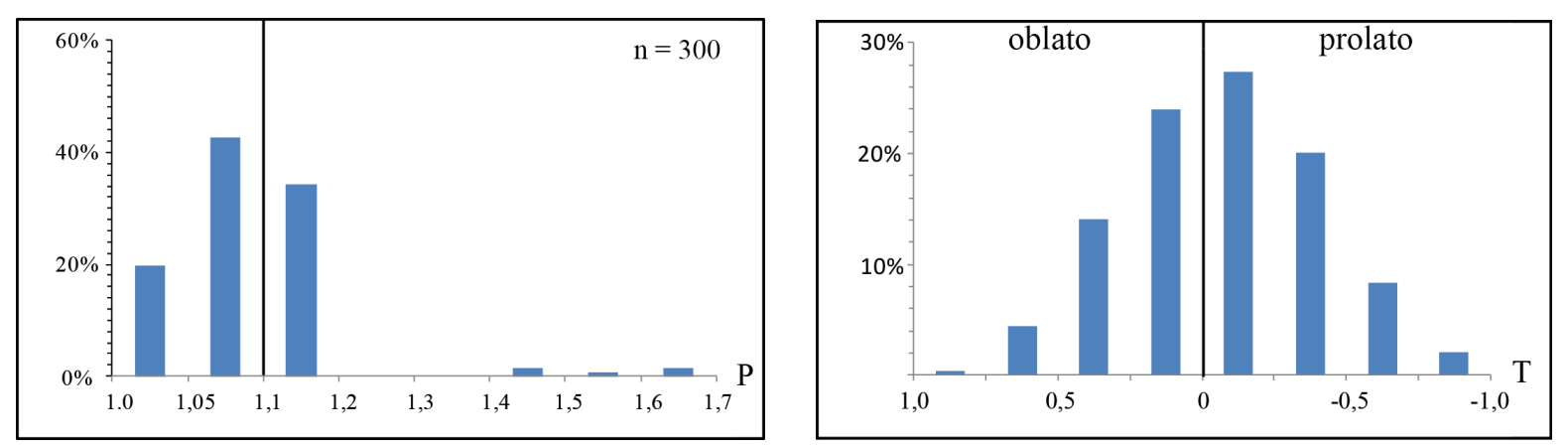

Figura 7-4: Histograma do grau de anisotropia $(P)$ e forma do elipsóide $(T)$ no granito Patrimônio Santo Antônio

\subsubsection{Granito São Domingos}

Nesse plúton foram coletadas 7 estações de ASM (48 espécimes), sendo que a susceptibilidade média é da ordem de 7,45 mSI e sua anisotropia é de 1,21 (dp. 0,09). Aproximadamente $36 \%$ dos espécimes possuem $\mathrm{P} \geq 1,20$ e apenas $12 \%$ apresentam $\mathrm{P}<1,10$. Já em relação à forma do elipsóide ocorre um predomínio de elipsóides prolatos, sendo que aproximadamente $75 \%$ possuem $T<-0,25$, enquanto apenas $4 \%$ são oblatos $(T>0,25)$ (fig. 7 $5)$.
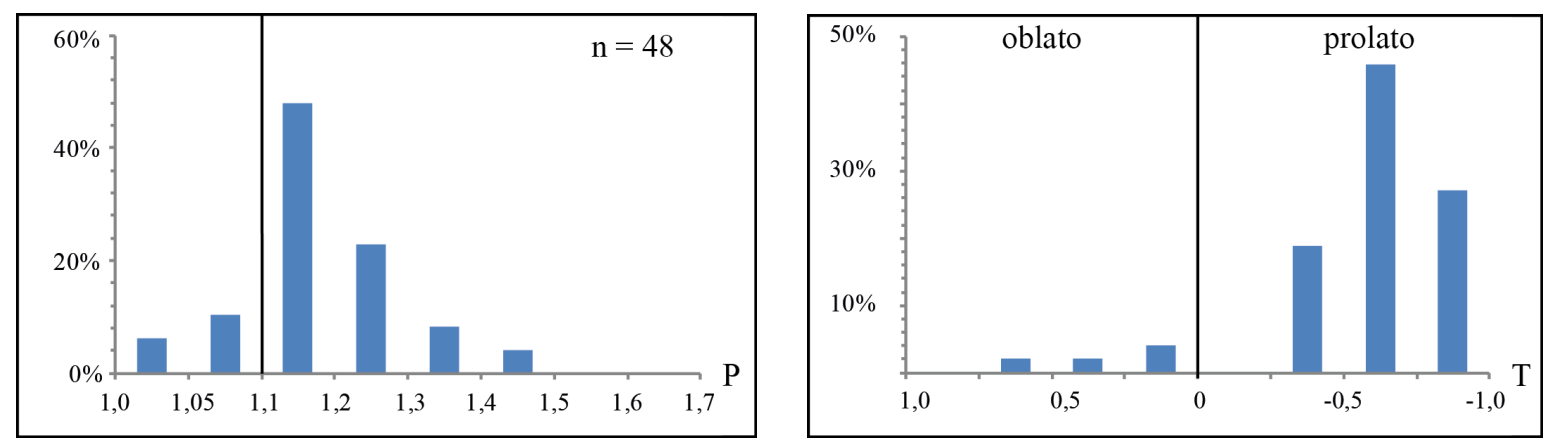

Figura 7-5: Histograma do grau de anisotropia $(P)$ e forma do elipsóide $(T)$ no granito São Domingos 


\subsubsection{Granito Ouro Verde}

Nesse granito foram coletadas 9 estações (67 espécimes) distribuídas conforme uma malha regular. A susceptibilidade magnética média é da ordem de 7,45 mSI, enquanto a anisotropia é de 1,119 (dp. 0,07). No histograma de freqüência do grau de anisotropia (fig. 76) observa-se que $36 \%$ dos espécimes possuem $\mathrm{P} \geq 1,20$ e apenas $4 \%$ apresentam valores inferiores a 1,10. Em relação à forma do elipsóide nota-se um equilíbrio: 16\% são prolatos (T $<-0,25)$ e $14 \%$ são oblatos $(\mathrm{T}>0,25)$.
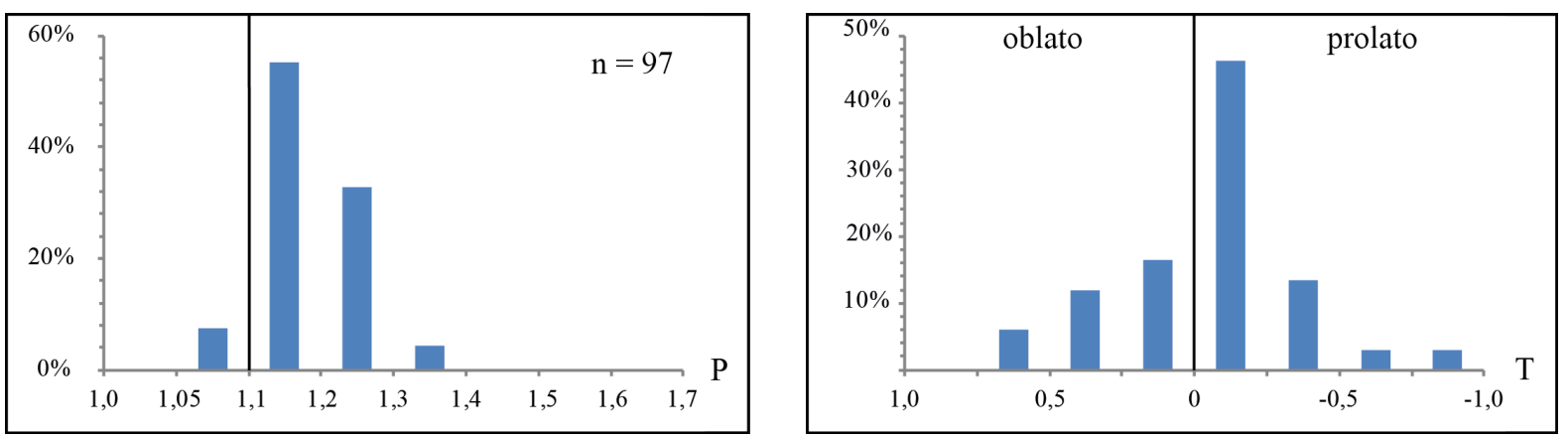

Figura 7-6: Histograma de frequência do grau de anisotropia $(P)$ e forma do elipsóide $(T)$ no granito Ouro Verde

\subsubsection{Granito Santa Rita}

No granito Santa Rita foram coletadas 14 estações (92 espécimes) distribuídas ao longo da intrusão dentro dos limites da área de estudo. A susceptibilidade magnética média é da ordem de 11,2 mSI e sua anisotropia é de 1,23 (dp. 0,11). Aproximadamente $45 \%$ dos espécimes apresentam $\mathrm{P} \geq 1,20$ (fig. 7-7). Já em relação à forma, a proporção de elipsóides prolatos $(\mathrm{T}<-0,25)$ é de $32 \%$, enquanto nos elipsóides oblatos $(\mathrm{T}>0,25)$ é de $24 \%$.
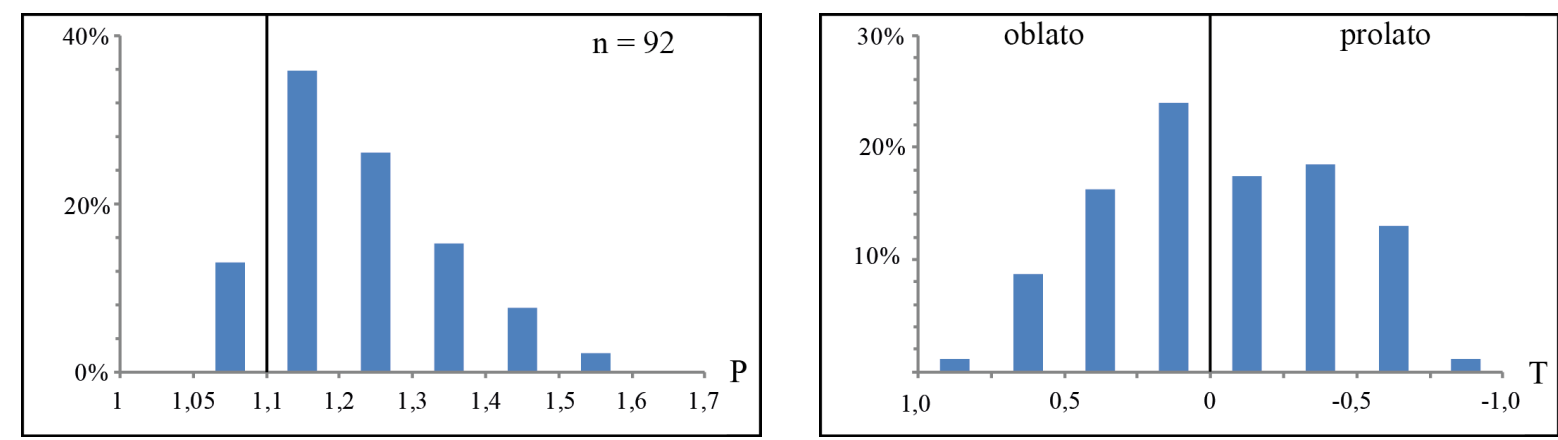

Figura 7-7: Histrograma de frequência do grau de anisotropia $(P)$ e forma do elipsóide $(T)$ do granito Santa Rita 


\subsection{Parâmetros direcionais}

Os parâmetros direcionais da trama magnética são representados pelas direções médias de $\mathrm{k}_{1}$ e $\mathrm{k}_{3}$, que correspondem respectivamente à lineação e à foliação magnética. Estes parâmetros podem ser avaliados qualitativamente ao se analisar a variação angular das elipses de confiança em relação às direções medias de cada estação de ASM. Sendo assim, quanto menor for à variação angular desta elipse, maior será o grau de confiabilidade da trama magnética. Jelinek (1978) demonstra que para uma trama magnética ser considerada definida o semi-ângulo do eixo maior da elipse de confidência $\left(\alpha \mathrm{k}_{1,3}\right)$ tem que ser igual ou inferior a $28^{\circ}$. Se $28^{\circ}<\alpha \mathrm{k}_{1,3} \leq 35^{\circ}$ a trama é classificada como moderadamente definida, e se $\alpha \mathrm{k} 1,3>$ $42^{\circ}$ a trama é considerada pobremente definida ou dispersa. Para os plútons da área de estudo, a trama magnética tanto para a lineação magnética $\left(\mathrm{k}_{1}\right)$ como para a foliação magnética $\left(\mathrm{k}_{3}\right)$ é bem definida $\left(\alpha \mathrm{k}_{1,3}<28^{\circ}\right)$. Na figura 7-8 observa-se que $92 \%$ das lineações e $89 \%$ das foliações magnéticas estão neste intervalo angular, enquanto apenas $3 \%$ das lineações e $6 \%$ das foliações estão dispersas. A pequena vantagem das tramas lineares bem definidas comprova a maior freqüência de elipsóides prolatos nos quatro granitos da área de estudo.

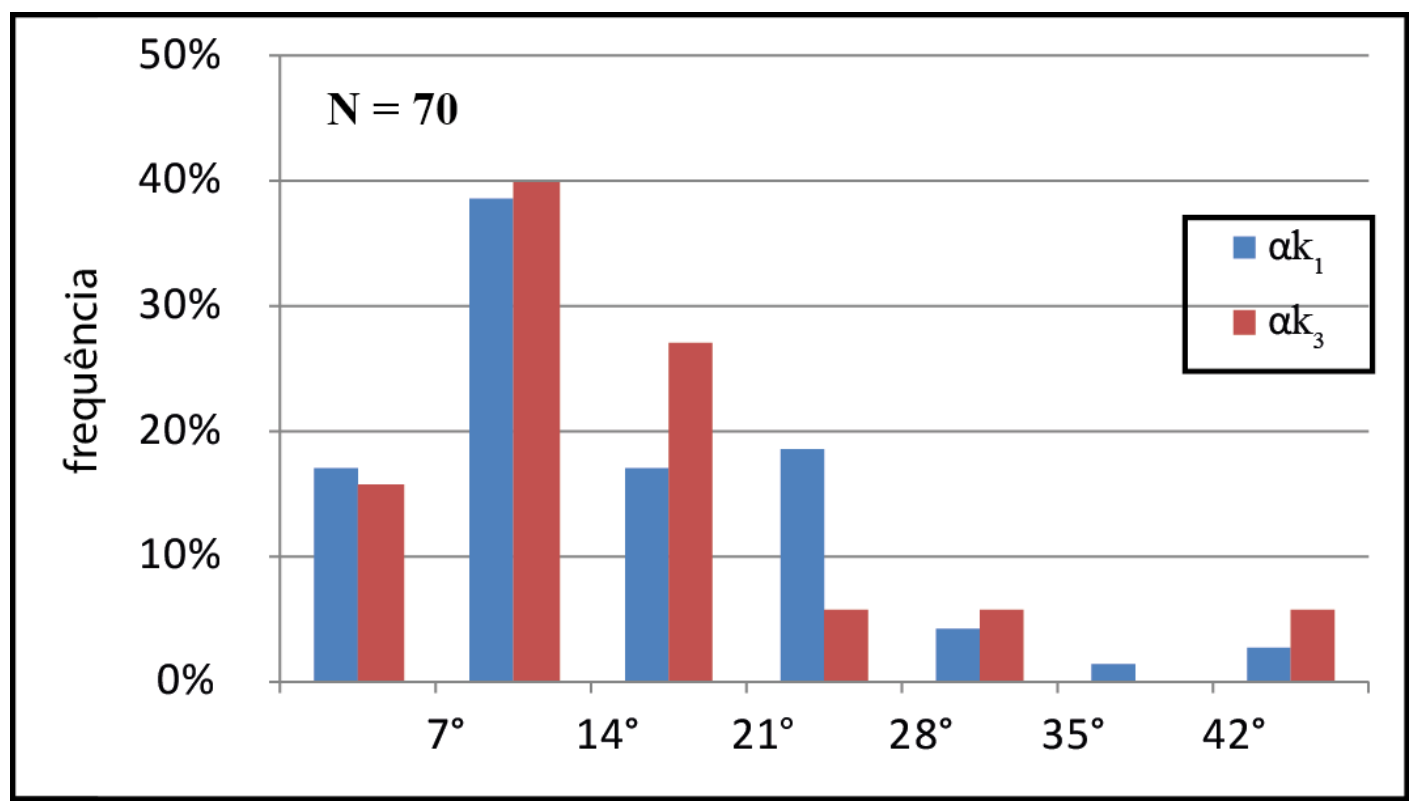

Figura 7-8: Variação angular da elipse de confiança das direções principais de ASM para cada estação. A trama é considerada definida se $\alpha k_{1,3}<28^{\circ}$ e dispersa se $\alpha k_{1,3}>42^{\circ}$ 
A trama magnética gerada pela média de cada estação apresenta um arranjo espacial bem definido tanto para a lineação magnética como para a foliação magnética (fig. 7-9). A lineação magnética é fortemente demarcada pela direção NNW-SSE, sendo que a maior densidade de pontos indica um sentido preferencial para NW. Já a foliação magnética também é distribuída pela direção NNW-SSE, porém é possível separar os pólos da foliação em dois grupos distintos. O autovetor máximo representa a maior concentração dos pólos, e neste caso predominam planos com mergulho de baixo a médio grau para ENE, enquanto o autovetor intermediário representa uma concentração mais baixa e dispersa, indicando planos com mergulho de médio a alto grau para WSW.

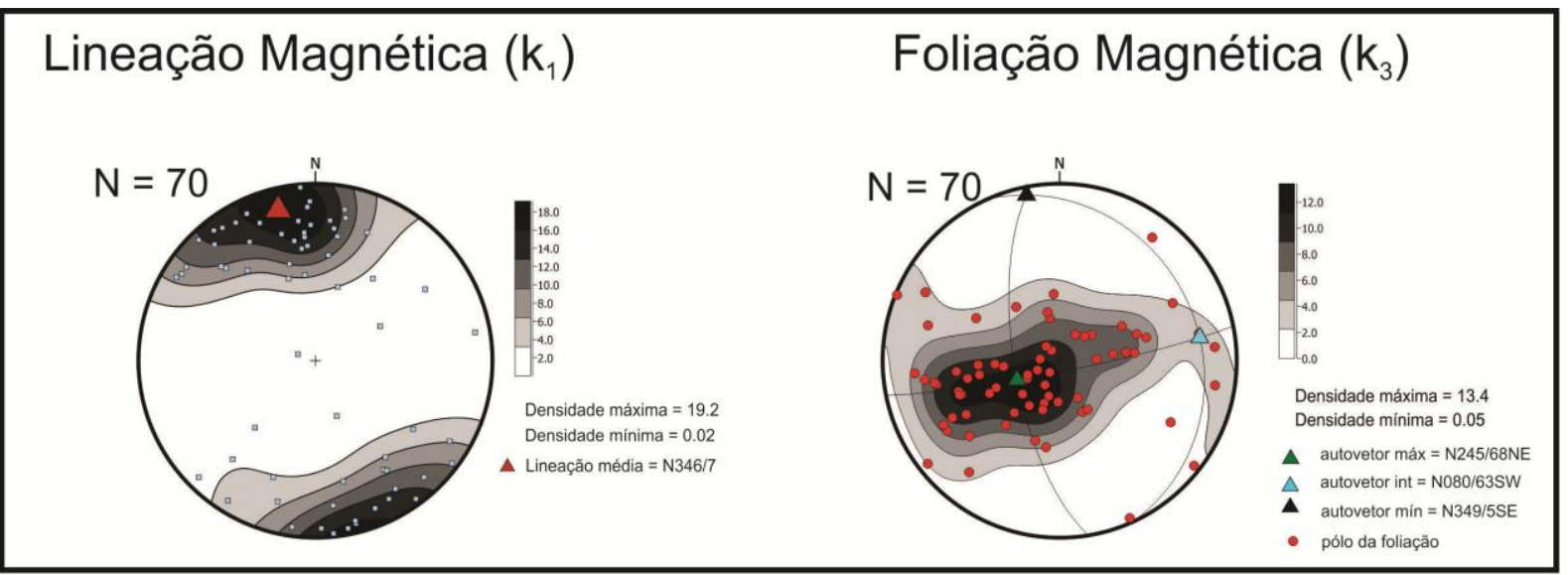

Figura 7-9: Orientação da trama magnética ( $k_{1}$, lineação magnética e $k_{3}$, foliação magnética)gerada pela média de cada estação nos plútons da área de estudo. Projeção estereográfica no hemisfério inferior. $N$, número de estações de ASM

No granito Patrimônio Santo Antônio é possível separar tanto a foliação magnética como a lineação magnética em dois domínios diferentes: a borda e o centro (linha tracejada vermelha na figura 7-10). O centro apresenta um padrão bastante difuso nas direções da foliação e da lineação magnética, entretanto em ambos predomina o mergulho de baixo grau. Já na borda deste plúton encontra-se um padrão bem ordenado tanto para $\mathrm{k}_{1}$ como para $\mathrm{k}_{3}$, com a foliação distribuída na direção NW-SE e mergulho de médio a alto grau para ENE. A lineação magnética também ocorre na mesma direção NW-SE, porém com mergulho de baixo a médio grau.

A trama magnética no plúton São Domingos (fig. 7-10) é bastante homogênea, com foliação magnética distribuída ao longo da direção NW-SE e mergulho de baixo a alto grau para NE. Já a lineação magnética é praticamente uniforme, com direção predominantemente para N e NW e mergulho de baixo grau. 

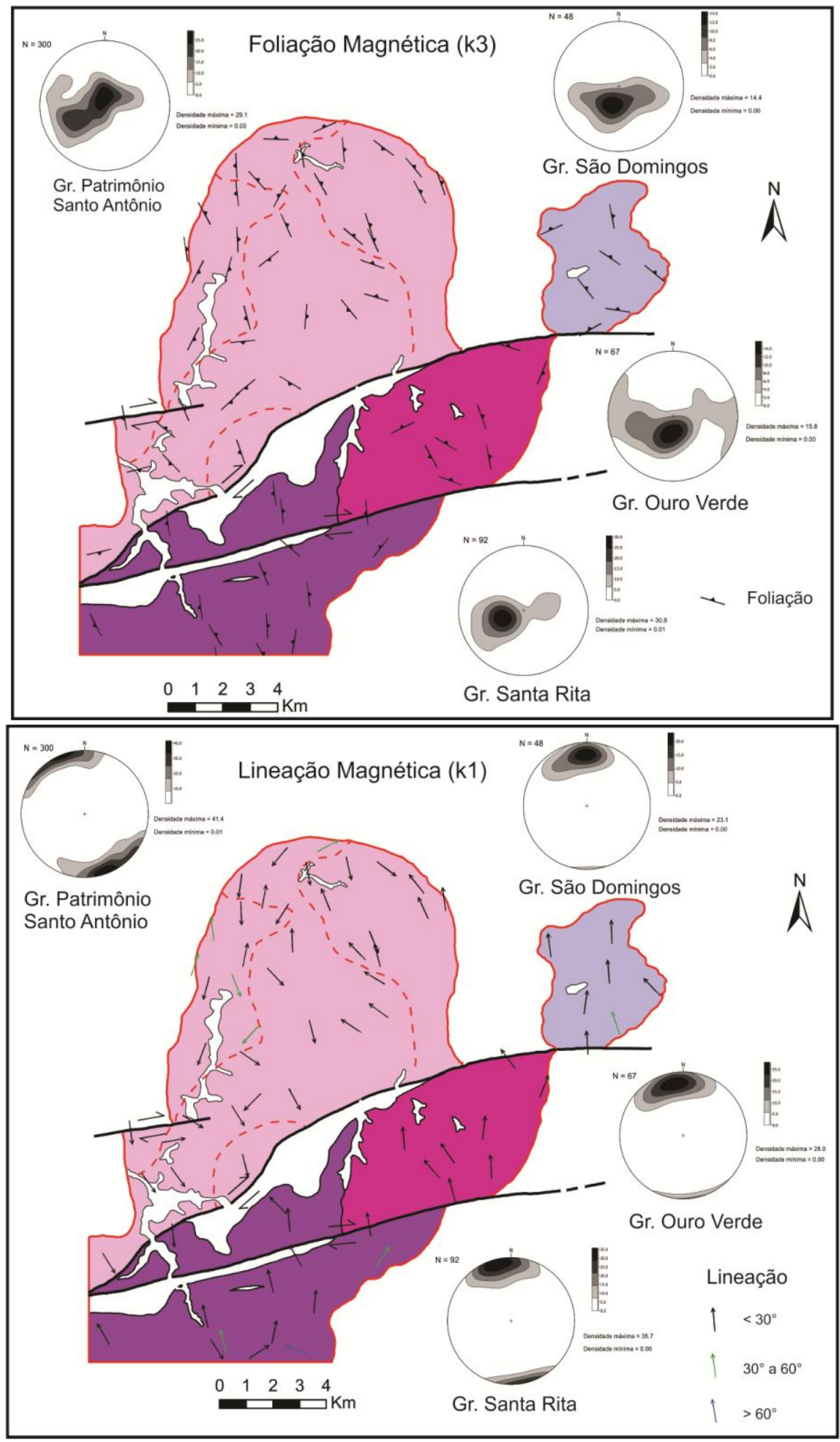

Figura 7-10: Mapas da foliação magnética (k3) e da lineação magnética (k1) e sua distribuição para cada plúton. Estereograma com contorno de densidade. Hemisfério inferior. Projeção em áreas iguais. $N$, número de espécimes 
No granito Ouro Verde a sua trama magnética (fig. 7-10) é semelhante aos demais plútons, sendo tanto a foliação como a lineação distribuídas na direção NNW-SSE. A foliação possui planos com mergulho de baixo a médio grau preferencialmente para NE e subordinadamente para SW. Já a lineação magnética forma um agrupamento sub-horizontal na porção N e NW do estereograma.

O plúton Santa Rita apresenta uma trama magnética bem definida (fig. 7-10), assim como os granitos Ouro Verde e São Domingos, com sua foliação e lineação distribuídas ao longo da direção NW-SE. Os pólos da foliação indicam um mergulho de médio a alto grau preferencialmente para NE, e as lineações estão alinhadas na direção NW-SE e mergulho predominantemente baixo.

\subsection{Trajetória da trama magnética}

A trajetória da trama magnética é uma forma de auxiliar a interpretação dos dados provenientes da trama magnética. A construção destas trajetórias é feita através de linhas que unem duas ou mais estruturas com orientação semelhante. O conjunto destas linhas pode revelar informações importantes em relação à forma do corpo granítico durante sua cristalização ou deformação. Desta forma, os resultados da trama magnética em conjunto com as possíveis trajetórias podem ser confrontados com o padrão estrutural das rochas encaixantes e assim colaborar para a elaboração de um modelo de alojamento e deformação dos granitos da área de estudo.

Na figura 7-11 destaca-se o Granito Patrimônio Santo Antônio por sua trama magnética indicar um padrão concêntrico tanto pelos dados da foliação como da lineação magnética. O setor central deste plúton é demarcado pelas foliações de baixo grau e em alguns casos quase horizontal. Já na borda leste e oeste nota-se o mergulho de alto grau das estruturas magnéticas concordantes com o padrão estrutural das rochas encaixantes. A união destes elementos caracteriza este plúton com uma forma semelhante a de uma cúpula ou domo.

Já os demais granitos apresentam uma trajetória quase uniforme e caracterizada especialmente pela direção NW-SE, já mencionada anteriormente nos parâmetros direcionais. 


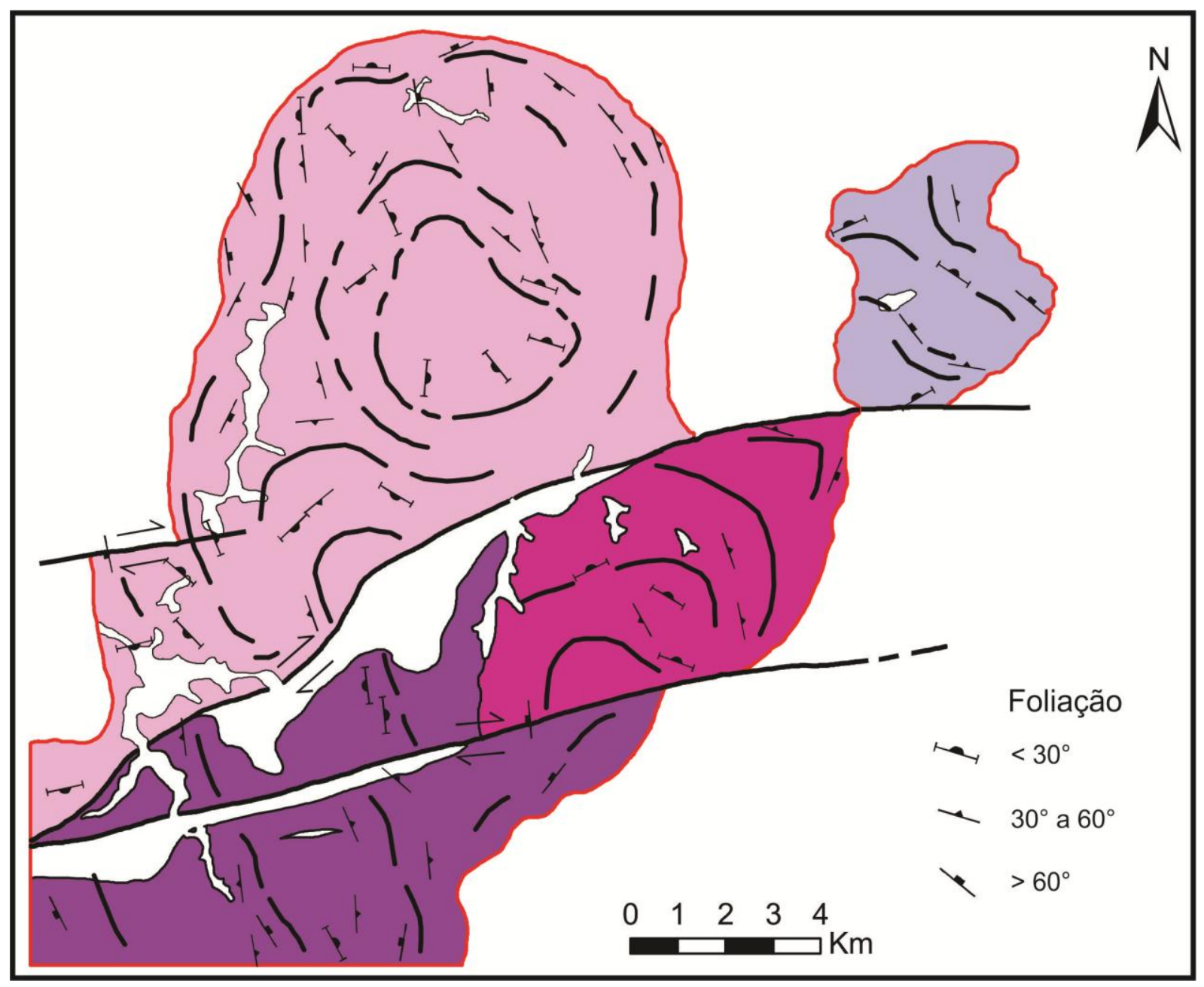

Figura 7-11: Trajetória da trama magnética. Detalhe para o padrão concêntrico do granito Patrimônio Santo Antônio 


\section{Discussões e considerações finais}

Os granitos Patrimônio Santo Antônio, Ouro Verde, São Domingos e Santa Rita apresentam uma elevada susceptibilidade e também uma forte anisotropia magnética. Os resultados das curvas de IRM e das análises termomagnéticas apontam que o principal mineral portador do sinal magnético é a magnetita multidomínio e, secundariamente, há uma pequena contribuição da Ti-hematita. Salazar (2010) estudou o Granito Capão Bonito, situado na Suíte Itú, comparando os dados da trama magnética (ASM) com os dados da trama mineral (silicatos). Este plúton apresenta uma mineralogia magnética semelhante aos granitos da área de estudo, assim como características geológicas e idade de cristalização. No Capão Bonito, o autor coletou amostras de 13 pedreiras destinadas à extração ornamental para comparar os dados obtidos pela anisotropia de susceptibilidade magnética (ASM) com os dados extraídos do estudo de orientação preferencial de forma (OPF) dos silicatos (máficos e K-feldspato). Os resultados indicam uma fraca a moderada obliqüidade entre a ASM e a OPF dos silicatos, porém com eixos principais da ASM e da OPF geralmente correspondentes. Desta forma pode-se afirmar que a trama magnética definida por magnetita e Ti-hematita é coerente com a trama de silicatos em rochas graníticas.

Sendo assim, ao analisar e correlacionar os dados da trama magnética com os dados estruturais das rochas encaixantes da área de estudo, nota-se o comportamento sintectônico destes granitos. Nos estereogramas das figuras 5-4 e 7-10 torna-se evidente a grande correlação entre a foliação e a lineação magnética com o padrão estrutural das rochas encaixantes pertencentes ao Domínio Estrutural Oeste. No caso da foliação, em ambos, é possível destacar a distribuição da direção quase uniforme NW-SE e com caimento de baixo a médio grau para WSW e ENE. Já a lineação magnética e a lineação das encaixantes possuem uma concentração idêntica na direção NNW-SSE. Estes dados combinados apóiam o modelo em que a deformação das encaixantes e o desenvolvimento da trama magmática dos granitos foram formadas ao mesmo tempo.

Nas ultimas décadas os modelos de alojamento de magmas graníticos foram baseados na integração dos mecanismos de ascensão magmática (transporte por diques, baloneamento, diapirismo, domeamento, assimilação) com regimes tectônicos ativos, principalmente em falhas transcorrentes (Hutton, 1988 Pitcher, 1992 Patterson \& Fowler, 1992 Román-Berdiel et al. 1997). Essa associação com o regime tectônico, que atualmente é um consenso, é uma forma de explicar a geração de espaços para o alojamento de plútons graníticos. Muitos desses 
modelos foram criados a partir de estudos de casos que apresentavam condições muito semelhantes aos granitos da área de estudo, como a colocação do magma em zona crustal rasa e associações de falhas transcorrentes com desenvolvimento de componente extensional para facilitar o alojamento.

Esses granitos da área de estudo apresentam características de um magma cristalizado em crosta rasa. Guimarães (2000) estimou a pressão de colocação dos granitos cálcioalcalinos do Complexo Cunhaporanga pelo método $\mathrm{Al}$ em hornblenda e obteve valores entre 2 a 4 kbar. Outro fator característico desta zona rasa é o metamorfismo de baixo grau nas rochas encaixantes do Grupo Itaiacoca. Por fim, a forma de cúpula da intrusão do Granito Patrimônio Santo Antônio mostrada na trajetória da trama magnética (fig. 7-11) e sua associação com a ocorrência de alguns tetos pendentes neste plúton e no stock São Domingos também evidenciam o nível crustal raso desta região.

Um modelo possível para o alojamento e deformação desses granitos é o desenvolvimento de sítios transtensivos (fig. 8-1) associadas ao movimento destral da Zona de Cisalhamento de Itapirapuã. A componente dilatacional favorece a criação de espaços para a colocação dos plútons. Ao analisar os esforços para a movimentação desta falha, nota-se a compressão evidenciada pelo eixo das dobras regionais NNE-SSW pertencentes ao Dominio Estrutural Oeste (fig. 5-4). Desta forma, o estiramento regional é máximo na direção NNWSSE.

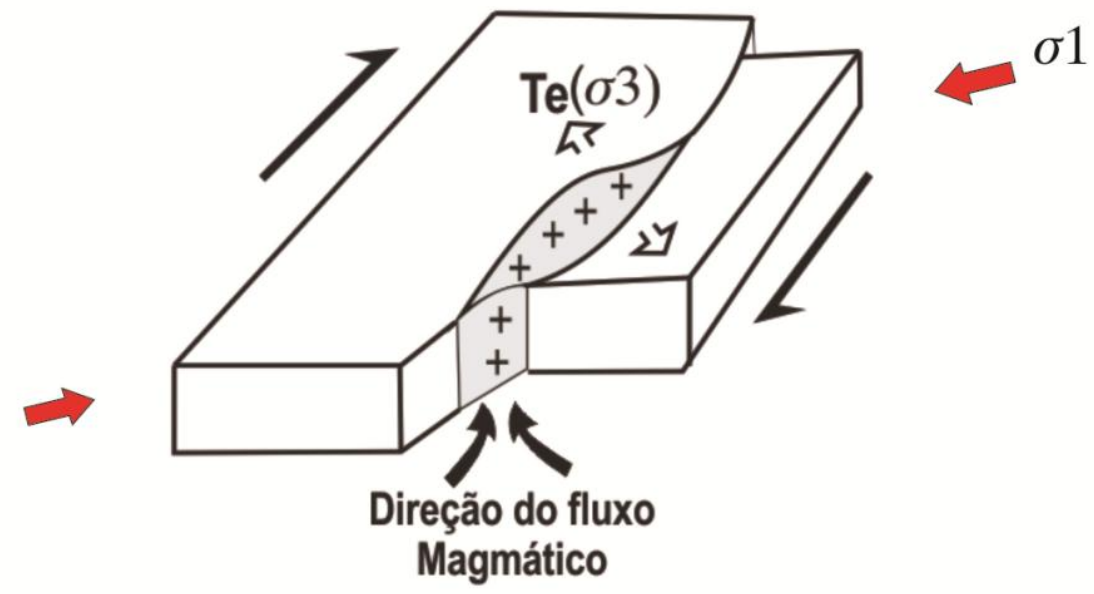

Figura 8-1: Modelo de alojamento de granito em sítios transtensivos (modificado de D'Lemos et al. 1992)

O Domínio da Zona de Cisalhamento de Itapirapuã apresenta movimentação tanto sinistral como destral. As falhas centrais desse domínio sugerem um deslocamento 
transcorrente sinistral. Esta relação é evidenciada principalmente pelos escassos indicadores cinemáticos encontrados na Formação Serra do Macaco e descritos no capitulo 5 no Domínio da Zona de Cisalhamento Itapirapuã. Já a falha ou Zona de Cisalhamento Bairro da Estiva mais próxima dos granitos e responsável pela separação dos domínios estruturais (Oeste e Zona de Cisalhamento Itapirapuã) sugere uma transcorrência destral. Souza (1990) descreve a ocorrência de veios escalonados e de forma sigmoidal com estrias horizontais associados a esta falha que indicam este deslocamento.

Desta forma o modelo pode ser representando baseado nestas duas hipóteses para o alojamento dos plútons graníticos: a transcorrência destral e a transcorrência sinistral.

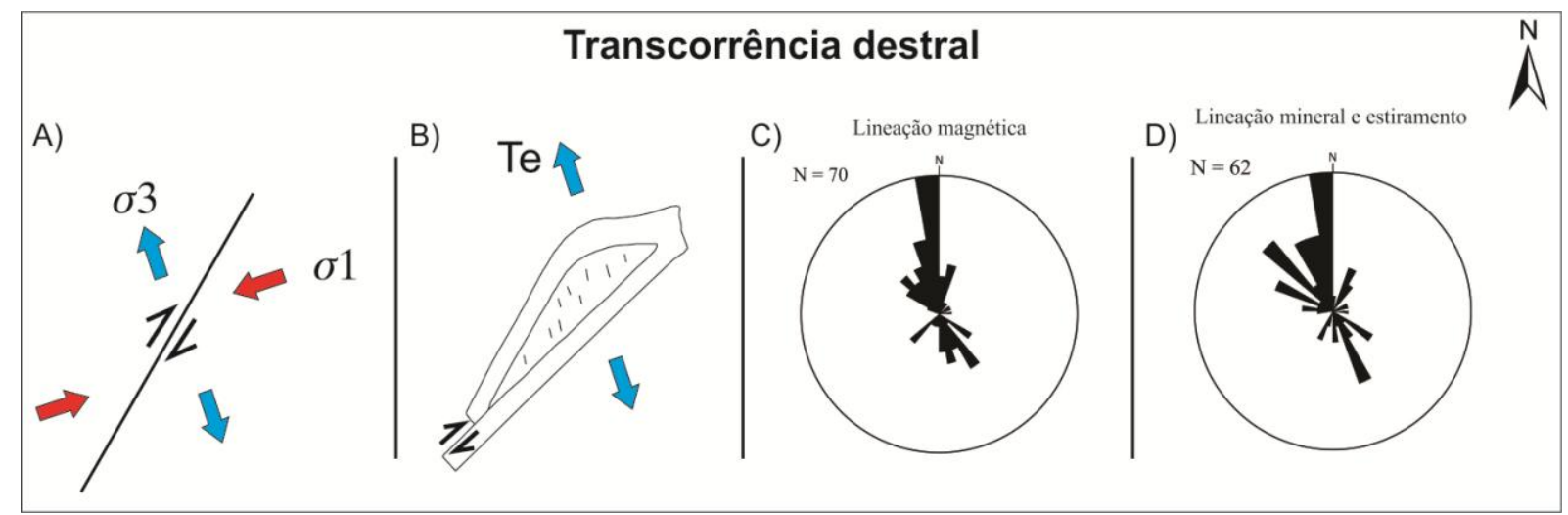

Figura 8-2: A) Modelo dos esforços na transcorrência destral. B) Sítio transtensiva gerado pela deformação que combina um componente de transcorrência destral e extensão (Te) (Román-Berdiel et al. 1997). C) Distribuição da lineação magnética nos plútons da área de estudo. D) Distribuição das lineações de estiramento e mineral no Domínio Estrutural Oeste

$\mathrm{Na}$ transcorrência destral a componente de compressão principal está disposta na direção ENE-WSW, padrão coerente com o eixo NNE-SSW das dobras no Domínio Estrutural Oeste (fig. 5-4), enquanto a componente extensional torna-se máxima na direção NNW-SSE (fig. 8-2A). O estiramento regional na direção NNW-SSE sugere uma geração de espaços através da transtensão (fig. 8-2B), favorecendo a colocação e alongamento dos plútons nessa mesma direção. Tanto os dados da lineação magnética obtida pela ASM (fig. 82C) como os dados de campo da lineação de estiramento e mineral do Domínio Estrutural Oeste são concordantes com a orientação do estiramento máximo. 


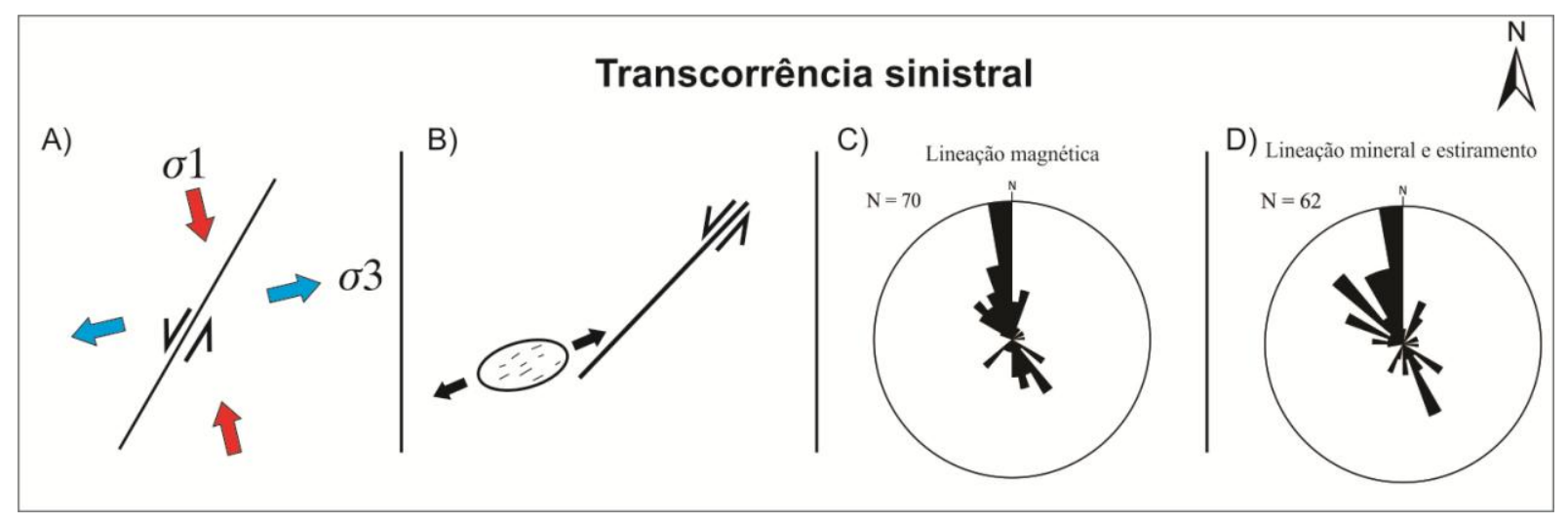

Figura 8-3: A) Modelo dos esforços na transcorrência sinistral. B) Modelo do estiramento na transcorrência sinistral (Román-Berdiel et al. 1997). C) Distribuição da lineação magnética nos plútons da área de estudo. D) Distribuição das lineações mineral e estiramento no Domínio Estrutural Oeste

Já na transcorrência sinistral, a componente compressional está posicionada na direção NNW-SSE e sua componente extensional está orientada na direção perpendicular WSW-ENE (fig. 8-3A). No modelo (fig. 8-3B) seria esperado uma direção de estiramento próximo a E-W ou seja, em clara dicordância com a orientação da lineação magnética e alongamento maior dos plútons.

O modelo de alojamento e deformação mais condizente com os dados obtidos neste trabalho é a transcorrência destral da Z.C.I. Uma possível interpretação para a cinemática sinistral observada em quartzitos finos da Formação Serra dos Macacos seria a de uma reativação tardia da falha com movimento oposto ao que favoreceu a colocação dos granitos.

Os dados geocronológicos revelam que o desenvolvimento da deformação transcorrente que favoreceu o alojamento dos magmas graníticos e a deformação regional está balizado pela idade U-Pb (SHRIMP) em zircão do granito Patrimônio Santo Antônio, em torno de $589 \pm 6$ Ma. Na Suíte Intrusiva Cunhaporanga, Prazeres Filho (2005) analisou um biotita monzogranito do Granito Santa Rita e obteve uma idade de cristalização U-Pb em zircão de $626 \pm 8$ Ma. Portanto, considerando que: (i) o monzogranito datado em c. 626 Ma é o mesmo Granito Santa Rita da área de estudo, e que (ii) a trama magnética é contínua do Ouro Verde, São Domingos e Patrimônio Santo Antônio, provavelmente a ASM do Santa Rita foi formada após a sua cristalização completa. Sendo Assim, o Granito Patrimônio Santo Antônio, e provavelmente o Ouro Verde e São Domingos, teriam se colocado entre os metassedimentos do Grupo Itaiacoca aproximadamente 30 Ma após a intrusão do granito Santa Rita. A intrusão do Patrimônio Santo Antônio parece contemporânea à intrusão dos 
granitos avermelhados pós-colisionais, como o Capão Bonito, que apresenta uma idade U-Pb (ID-TIMs) em zircão de $586 \pm 3$ Ma (Leite et al., 2007).

Prazeres Filho (2005) comparou as Suítes Intrusivas Graníticas Três Córregos (SITC) e Cunhaporanga (SIC) utilizando os dados geocronológicos (ID-TIMS e U-Pb SHRIMP), além de dados da litoquímica e da geoquímica isotópica do zircão e da rocha total. Os estudos litoquímicos e isotópicos revelaram as diferenças existentes entre as fontes crustais de origem e o comportamento dos álcalis para os dois batólitos. Porém as idades U-Pb ID-TIMS e SHRIMP em zircões indicam que ambos os batólitos teriam se formado num período de 70 Ma, mais precisamente entre 650-590 Ma. O autor acredita que estes batólitos foram originados por uma sucessão de eventos magmáticos no final do Neoproterozoico, e que esses eventos ocorreram em um provável ambiente de arco magmático continental. Na etapa inicial, entre 650-620 Ma, ocorreria a geração de um magmatismo cálcio alcalino de baixo a médio K constituído por tonalitos a quartzo-monzodioritos. Esse evento estaria restrito ao SITC. Posteriormente o SITC e o SIC teriam sido assimilados e sucedidos por um magmatismo cálcio alcalino de alto $\mathrm{K}$ entre 620-590 Ma, pico da geração de diversos granitos sincolisionais de ambas as suítes. No estágio final, em regime francamente pós-colisional associado a uma tectônica transcorrente-extensional, se alojaram na crosta superior os plútons tardios, tais como o Patrimônio Santo Antônio e o Capão Bonito. 


\section{Referências bibliográficas}

ALGARTE, J.P. A influência dos arqueamentos cratônicos no condicionamento das alcalinas dos estados de São Paulo e Paraná. In: CONGRESSO BRASILEIRO DE GEOLOGIA, 26., 1972, Belém. Anais...Belém: SBG, 1972. v.1, p.65-69.

ALGARTE, J.P. et al. Projeto Sudeste do Estado de São Paulo; relatório final. São Paulo, Convênio DNPM/CPRM, 1974.

ALMEIDA, F.F.M. Collenia itapevensis sp. n. - um fóssil pré-cambriano do Estado de São Paulo. Boletim da Faculdade de Filosofia, Ciências e Letras da Universidade de São Paulo. XLV, Geologia n.1, p.89-106. 1944.

ALMEIDA, F.F.M. Novas ocorrências de fósseis no pré-cambriano brasileiro. Anais da Academia Brasileira de Ciências, v.29, p.63-72,1956.

ALMEIDA, F. F. M. et al. The Precambrian evolution of the South American cratonic margin south of Amazonas River. In: NAIRN, A.E.M. \& STILLE, F.G. (eds). The ocean basin and margins v.1. New York: Plenum, 1973. 733p. il. p.411-446.

ALMEIDA, F. F. M. et al. Províncias estruturais brasileiras. In: SIMPÓSIO DE GEOLOGIA DO NORDESTE, 8, 1977, Campina Grande. Atas... Campina Grande: SBG, 1977. 499p. il. (Boletim do Núcleo Nordeste da SBG, 6) p.363-391.

ALMEIDA, F. F. M. et al. Brazilian structural provinces: an introduction. Earth Sci. Rev., v.17, p.1-29, 1981.

BARBARIN, B. Granitoids: main petrogenetic classifications in relation to origin and tectonic setting. Geological Journal., v.25, p. 227-238, 1990.

BATOLLLA JÚNIOR et al. Projeto Leste do Paraná, Folha Curitiba (SG.22-X-D-1). Relatório Final, v.1, São Paulo. Convênio DNPM/CPRM, 250p 1977.

BEST, M. G. \& CHRISTIANSEN, E. H. Igneous Petrology. Oxford: Blackwell Science, $2001,458 p$.

BIONDI, J.C. et al. Mapa geológico do Estado do Paraná, 1:650.000. Brasília, MME/DNPM/MINEROPAR, 1989.

BISTRICHI, C. A.; ALMEIDA, M. A.; STEIN, D. P. Geologia das Folhas Barra do Chapéu (SG.22-X-B-I-4) e Araçaiba (SG.22-X-B-II-3), Estados de São Paulo e Paraná. (IPT.

Relatório, 22 150) (inédito), 1985. 
BORRADAILE G. J.; HENRY B. Tectonic application of magnetic susceptibility and its anisotropy. Earth Sciences. Review, vol. 42: 49-93, 1997.

BOUCHEZ JL. Granite is never isotropic: an introduction to AMS studies in granitic rocks. in: Bouchez J.L.et al. (Eds), Granite: from segregation to emplacement fabrics. Kluwe Acad. Publ., Dordrecht, p. 95-112, 1997.

BOUCHEZ JL. Anisotorpié de susceptilité magnétique et fabrique des granites. Comptes Rendus Acádemie des Sciences. Paris Série, 2 vol. 330:1-14.et al. (Eds), Granite: from segregation to emplacement fabrics. Kluwe Acad. Publ., Dordrecht, p. 95-112, 2000.

BRITO NEVES, B. B.; CAMPOS NETO, M. C.; FUCK, R. A., 1999. From Rodinia to Western Gondwana: An approach to the Brasiliano-Pan African Cycle and orogenic collage. Episodes, v.22, p. 155-166, 1999.

BROWN, M.; SOLAR, G. S. Granite ascent and emplacement during contractional deformation in convergent orogens. Journal of Structural Geology, v.20, p. 1365-1393, 1998.

CALTABELOTI, F. P. et al. Geologia da Folha Itararé - SG-22-X-B-I (Escala 1:100.000).. In: XLV CONGRESSO BRASILEIRO DE GEOLOGIA, 2010, Belém do Pará. Anais do XLV Congresso Brasileiro de Geologia, 2010. v. CD-ROM.

CAMPANHA, G. A. C.; BRITO NEVES, B. B. Frontal and oblique tectonics in the Brazilian shield. Episodes, v.27, p. 255-259, 2004.

COMPSTON, W.; WILLIAMS, I. S. ; KIRSCHVINK, J. L. . Zircon U-Pb ages for the Early Cambrian time-scale. Journal of Geological Society of London, v.149, p. 171-184, 1992.

CRUDEN, A. R. Emplacement and growth of plutons: implications for rates of melting and mass transfer in continental crust. In: BROWN, M.; RUSHMER, T. Evolution and Differentiation of the Continental Crust. Cambridge University, 2005, p. 455-519.

CUREVAL 8. Thermomagnetic curves browser and analyzer for Windows, Version 8.0. Disponível em: http://www.agico.com/software/cureval/download.php.

FAIRCHILD, T. R. Conophyton and other columnar stromatolites from the Upper precambrian Açungui Group near Itapeva, SP, Brazil. In: SIMPÓSIO REGIONAL DE GEOLOGIA, 1., 1977, São Paulo. Atas... São Paulo: SBG, 1977. p.179-198.

FALEIROS, F. M. Evolução de terrenos tectono-metamórficos da Serrania do Ribeira e Planalto Alto Turvo (SP, PR). 2008, 306p. Tese (Doutorado), Instituto de Geociências, Universidade de São Paulo, São Paulo, 2008. 
FERREIRA, F. J. F.; FRUCHTING, A.; GUIMARÃES, G. B.; ALVES, L. S.; MARTIN, V. M. O.; ULBRICH, H. H. G. J. Levantamentos gamaespectrométricos em granitos diferenciados. II: o exemplo do Granito Joaquim Murtinho, Complexo Granítico Cunhaporanga, Paraná. Geologia USP: Série Científica, v.9, p. 55-72, 2009.

FUCK, R. A.; MARINI, O. J.; TREIN, E. Contribuição ao estudo das rochas graníticas do Estado do Paraná. Boletim Paranaense de Geociências, v. 23-25, p.183-221, 1967.

FUCK, R. A., BRITO NEVES, B. B., SCHOBBENHAUS, C. Rodinia descendants in South América. Precambrian Research, v. 160, p. 108-126, 2008.

GIMENEZ FILHO, A. Evolução do Complexo Três Córregos a noroeste de Apiaí-SP. 118p. 1993. Dissertação (Mestrado) - Instituto de Geociências, Universidade de São Paulo, São Paulo, 1993.

GEOSOFT INC. Oasis Montaj User’s Manual Version 7.2, 2010. Disponível em: www.geosoft.com, 290p.

GRAHAM J. W. Magnetic susceptibility anisotropy: an exploited petrofabric element. Geologycal Society of America. Abstract Program, vol. 65: 1257-1258, 1954.

GUIMARÃES, G. B. O Complexo Granítico Cunhaporanga na região de Joaquim Murtinho, Piraí do Sul (PR): caracterização faciológica das rochas granitóides. 1995, 144p. Dissertação (Mestrado) - Instituto de Geociências, Universidade de São Paulo, São Paulo, 1995

GUIMARÃES, G. B. As Rochas Granitóides do Complexo Granítico Cunhaporanga, Paraná: aspectos geológicos, geofísicos, geoquímicos e mineralógicos. 2000, 230p. Tese (Doutorado) - Instituto de Geociências, Universidade de São Paulo, São Paulo, 2000.

GUIMARÃES, G. B.; FERREIRA, F .J. F.; ULBRICH, H. H. G. J.; FORLIN, M. The Aerogeophysical Project Serra do Mar Sul in the region of the Cunhaporanga Granitic Complex, Paraná, southern Brazil: analysis of the gamma-ray spectrometric survey. Revista Brasileira de Geofísica, Rio de Janeiro, v. 19, n. 1, p. 3-17, 2001.

HASUI, Y.; CARNEIRO, C. D. R.; BISTRICHI, C. A. Estrutura e tectônica do PréCambriano de São Paulo e Paraná. Anais da Academia Brasileira de Ciências, v.52, p: 61$76,1980$. 
HUTTON, D. H. W. Granite emplacement mechanisms and tectonic controls: inferences from deformation studies. Transactions of the Royal Society of Edinburgh: Earth Sciences, v.79, p. 245-255, 1988.

ISHIHARA, S. The magnetite-series and ilmenite-series granitic rocks. Mining Geology, v.27, p. 293-305, 1977.

JELINEK, V. Statistical processing of anisotropy of magnetic susceptibility measured on groups of specimens. Studia geoph. et geodetica, v.22, p. 50-62, 1978.

JELINEK, V. Characterization of the magnetic fabrics of rocks. Tectonophysics, v.49, p. 6367, 1981.

LEITE J.R.; HEAMAN L.M.; JANASI VA, MARTINS L.; CREASER R.A. The late- to postorogenic transition in the Neoproterozoic Agudos Grandes Granite Batholith (Apia1' Domain, SE Brazil): Constraints from geology, mineralogy, and $\mathrm{U}-\mathrm{Pb}$ geochronology. Journal of South American Earth Sciences. Vol. 23: 193-212, 2007.

LEMOS, R. S. D.; BROWN, M.; STRACHAN, R. A. Granite magma generation, ascent and emplacement within a transpressional orogen. Journal of the Geological Society, London, v.149, p. 487-490, 1992.

LUDWIG, K. R. User's manual for Isoplot/Ex Version 2.49: a geochronological toolkit for Microsoft Excel. Berkeley Geochronological Center. Special Publication 1a, 55p

MURATORI, A. et al. Folha Geológica de Serra das Antas. Comissão da Carta Geológica do Paraná. Curitiba-PR, 1970.

NYE FJ, Physical properties of crystals. Oxford University Press, New York, 322p, 1957.

OLIVEIRA, E. P. Geologia do Estado do Paraná. Bol.Min. Agric. Ind.Com., Rio de Janeiro, v. 5, p. 77-143, 1916.

OLIVEIRA, E. P. Geologia e recursos minerais do Estado do Paraná. Rio de Janeiro, Serviço Geológico e Mineralógico do Brasil, 172 p. (Monografia, 6), 1927.

PATERSON, S. R.; FOWLER, T. K. Jr. Re-examining pluton emplacement processes. Journal of Structural Geology, v.15, p. 191-206, 1993.

PITCHER, W. S. Controls of upwelling and emplacement: the response of the envelope: balloons, pistons and reality. In: PITCHER, W. S. The nature and origin of granite. London: Chapman \& Hall, 1993. 387 p. 
PRAZERES FILHO, H. J. et al. Mapa Geológico 1:50.000 da porção centro-sul da Faixa Itaicoca, PR. In: CONGRESSO BRASILEIRO DE GEOLOGIA, 40. 1998, Belo Horizonte. Anais... SBG, 1998, p. 36.

PRAZERES FILHO, H. J. Litogeoquímica, geocronologia (U-Pb) e geologia isotópica dos complexos graníticos Cunhaporanga e Três Córregos, Estado do Paraná. 2000, 180 p. Dissertação (Mestrado) - Instituto de Geociências, Universidade de São Paulo, São Paulo, 2000.

PRAZERES FILHO, H. J. Caracterização geológica e petrogenética do Batólito Granítico Três Córregos (PR-SP): Geoquímica isotópica (Nd-Sr-Pb), idades (ID-TIMS/SHRIMP) e $\delta^{18}$ O em zircão. 2005, 207 p. Tese (Doutorado), Instituto de Geociências, Universidade de São Paulo, São Paulo, 2005.

REIS NETO, J. M. Faixa Itaiacoca: Registro de uma colisão entre dois blocos continentais no Neoproterozóico. 1994, 296p. Tese (Doutorado) - Instituto de Geociências, Universidade de São Paulo, São Paulo, 1994.

RIBAS, S. M. Reconhecimento geológico do "Complexo Granítico Cunhaporanga". Relatório de pesquisa (inédito). Curitiba, MINEROPAR, 1981.

ROCHETTE, P.; JACKSON, M.; AUBOURG, C. Rock magnetism and the interpretation of magnetic susceptibility. Review Geophysics, vol. 30: 209-226, 1992.

RODRIGUES, S. W. O. et al. . Geologia Preliminar da Folha Itararé (SG-22-X-B-I). In: XI SIMPÓSIO DE GEOLOGIA DO SUDESTE, 2009, São Pedro. Anais do XI Simpósio de Geologia do Sudeste. Rio Claro : Divisa Grafica/Editora, 2009. p. 26-26.

ROMÁN-BERDIEL L, T.; GAPAIS, D.; BRUN, J.P. Granite intrusions along strike slip zones in experiments and nature. American Journal of Science, v.297,p. 651-678, 1997.

SANTOS, M. S.; FELIPE, R. S. Reconhecimento geológico da Faixa Três Córregos. Relatório Interno, Curitiba, MINEROPAR, 1980.

SIGA JUNIOR, O.; BASEI, M. A. S.; SATO, K.; PRAZERES FILHO, H. J.; CURY, L. F.; WEBER, W.; PASSARELLI, C. R.; HARARA, O. M.; REIS NETO, J. M. U-Pb (Zircon) Ages of Metavolcanic Rocks, from the Itaiacoca Group: Tectonic Implications. Geologia USP: Série Científica, v. 3, p. 39-50, 2003.

SIGA JUNIOR, O.; BASEI, M. A. S.; PASSARELlI, C. R.; SATO, K.; CURY, L. F.; MCREATH, I. Lower and Upper Neoproterozoic magmatic records in Itaiacoca Belt 
(Paraná-Brazil): Zircon ages and lithostratigraphy studies. Gondwana Research, v.15, p. 197-208, 2009.

SILVA, A. T. S. F. et al. Projeto integração e detalhe geológico no Vale do Ribeira; relatório final de integração geológica. São Paulo, convênio DNPM/CPRM. 15v, São Paulo, 1981.

SILVA, D. C.; MANTOVANI, M. S. M. . Projeto Aerogeofisico Serra do Mar Sul: Uma Abordagem Semi-Quantitativa. Revista Brasileira de Geociências, BRASIL, v.24, n. 2, p. 120-127, 1994.

SOUZA, A. P. Mapa Geológico na escala 1:50.000 e esbouço de evolução tectônica e sedimentar do Grupo Itaiacoca, nas folhas Barra do Chapéu e Ouro Verde (SP-PR). 1990, 200p. Dissertação (Mestrado) - Instituto de Geociências, Universidade de São Paulo, São Paulo, 1990.

SOARES, P. C.; STEVANATTO, R.; CAMARGO, C. R. Geologia do noroeste da Faixa Itaiacoca - Paraná. In: I SIMPÓSIO SUL-BRASILEIRO DE GEOLOGIA, 3.,1987, Curitiba, Atas... Curitiba: SBG, 1987, v.1, p. 245-262.

SZABÓ, G. A. J.; ANDRADE, F. R. D.; GUIMARAES, G. B.; CARVALHO, F. M. S.; MOYA, F. A. As jazidas de talco no contexto da história metamórfica dos metadolomitos do Grupo Itaiacoca, PR. Geologia USP: Série Científica, v. 5, p. 13-31, 2006.

THEODOROVICZ, A. et al. Projeto Engenheiro Maia-Ribeirão Branco. Relatório Final. v.1. São Paulo, CPRM, 1986.

TREIN, E. et al. . Revisão da Formação Itaiacoca: Identificação de uma sequência metavulcano-sedimentar em Abapã (PR). In: V SIMPÓSIO DE REGIONAL DE GEOLOGIA, 5., 1985, São Paulo. Atas... São Paulo: SBG, 1985, p.169-185.

ULBRICH, H. H. G. J. ; ULBRICH, M. N. C. ; FERREIRA, F. ; ALVES, L. S. ; GUIMARAES, G. ; FRUCHTING, A. . Levantamentos gamaespectrométricos em granitos diferenciados. I: Revisão da metodologia e do comportamento geoquímico dos elementos K, Th e U. Boletim IG-USP. Série Científica, v. 9, p. 33-53, 2009.

VIGNERESSE, J.L. Control of granite emplacement by regional deformation. Tectonophysics, ed. 149, p. 63-67, 1995

WERNICK, E.; RIGO JR, L. ; GALEMBECK, T. M. B.; WEBERDIEFENBACH, K. Os complexos granitóides Cunhaporanga e Três Córregos (PR): Zoneamento magmático e implicações geotectônicas. Revista Geociências. São Paulo, v.9, p. 67-86, 1990. 
WHITE, A. J. R.; CHAPPEL, B. W. Granitoid types and their distribuition in the Lachand Fold Belt, southeastern Australia. Geological Society of America, Bulletin, v.159, p. 21-34, 1983. 
ANEXO I - MAPA DE AFLORAMENTOS E ESTAÇÕES DE ASM 


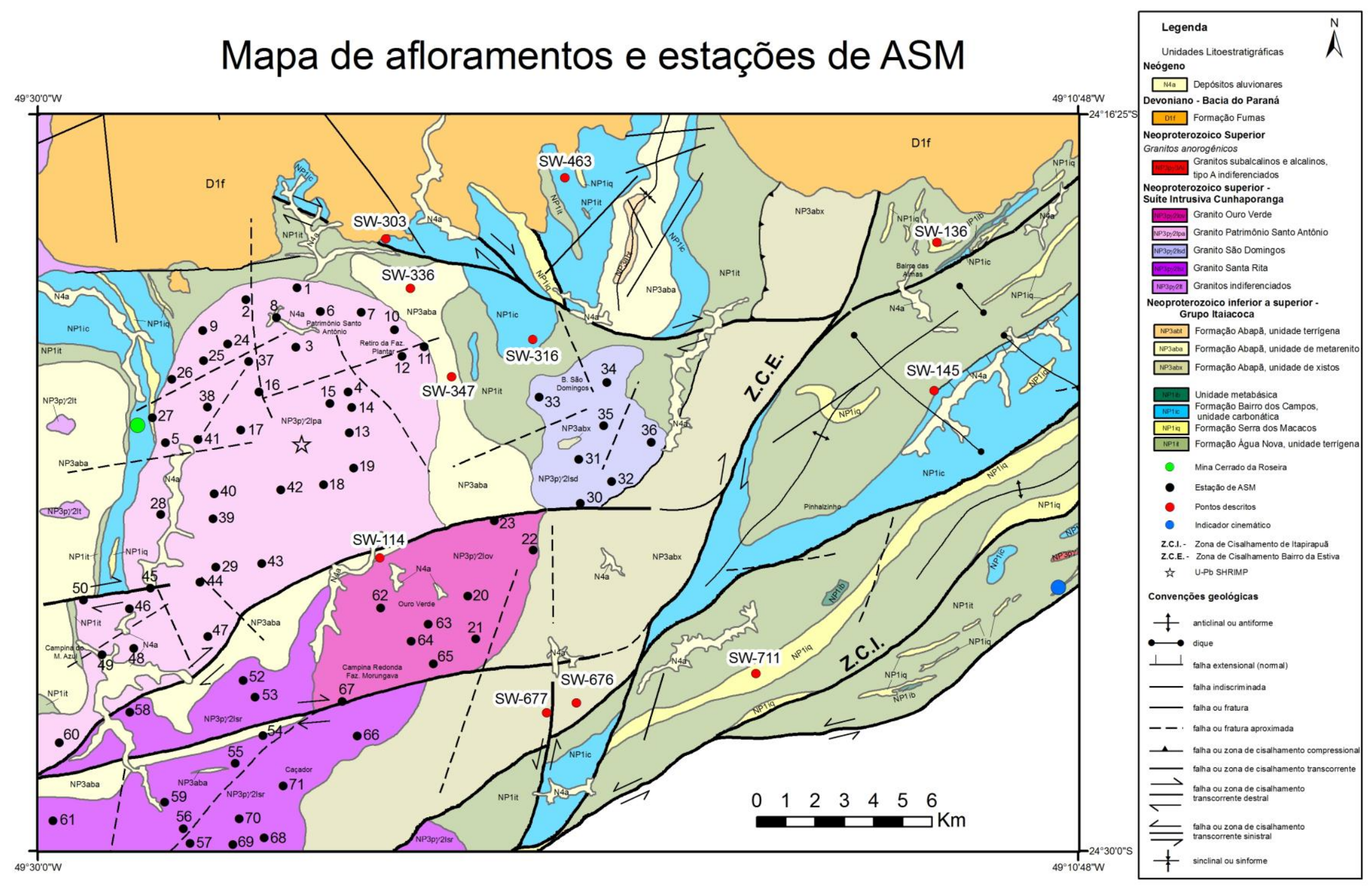

